
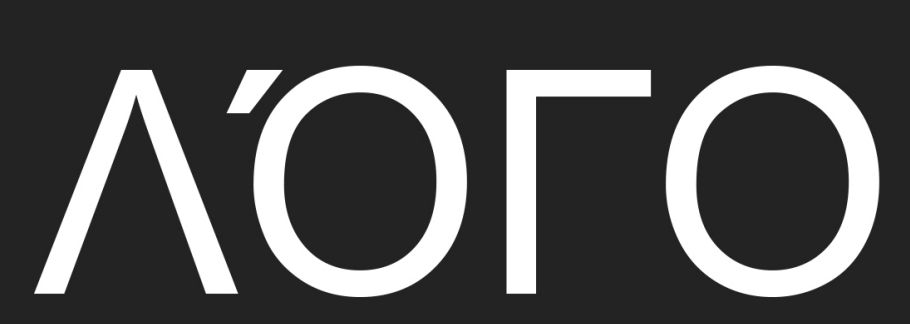

\title{
COLLECTION OF SCIENTIFIC PAPERS
}

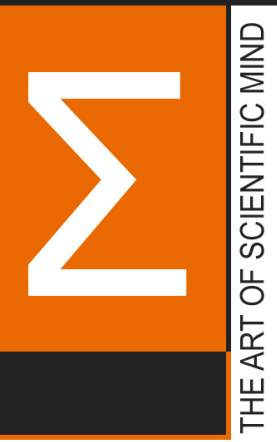

WITH PROCEEDINGS OF THE INTERNATIONAL SCIENTIFIC AND PRACTICAL CONFERENCE

\section{SCIENTIFIC DISCOVERIES: PROJECTS, STRATEGIES AND DEVELOPMENT}

OCTOBER 25, $2019 \cdot$ EDINBURGH, SCOTLAND, UK $\mathbb{X}$

\section{VOLUME 3}

DOI 10.36074/25.10.2019.v3

ISBN 978-617-7171-83-5

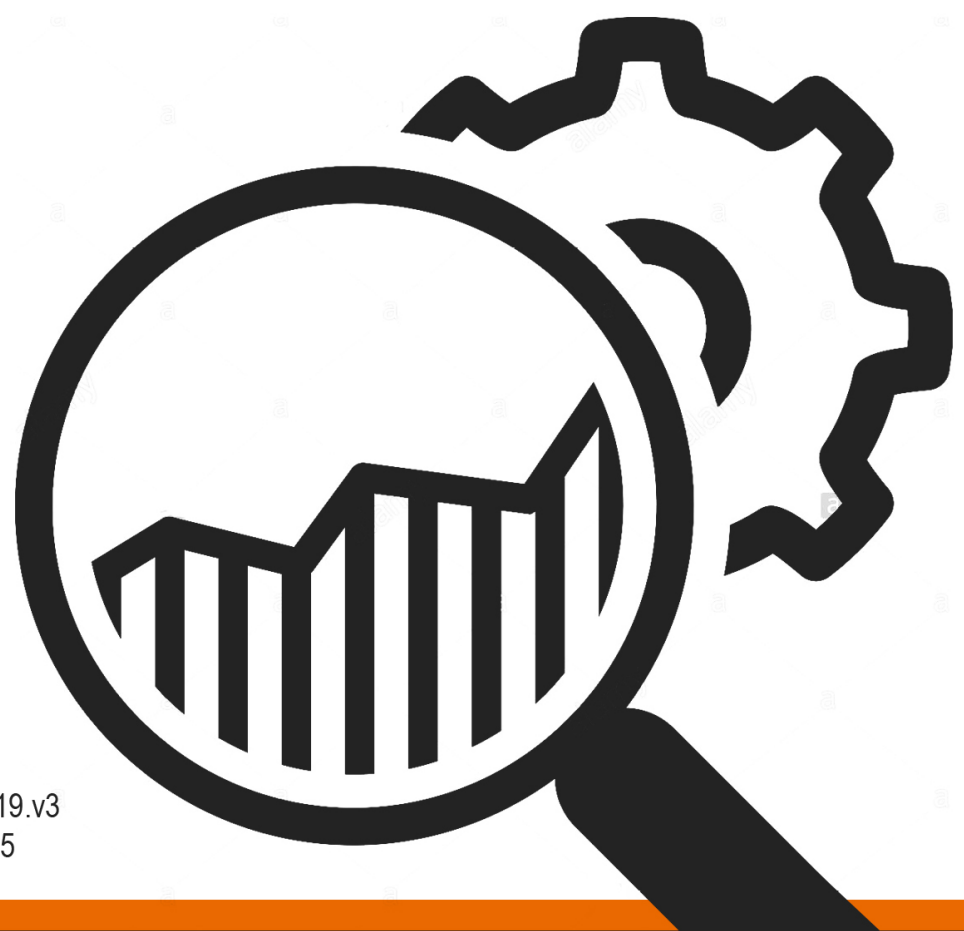



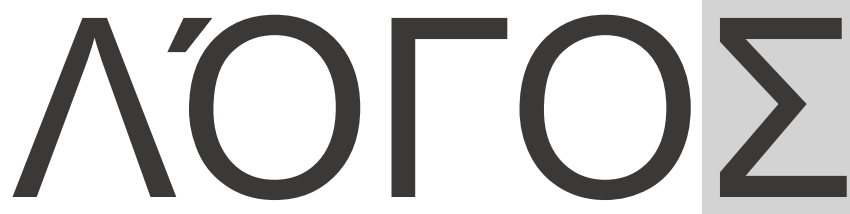

COLLECTION OF SCIENTIFIC PAPERS

WITH PROCEEDINGS OF THE INTERNATIONAL SCIENTIFIC AND PRACTICAL CONFERENCE

«SCIENTIFIC DISCOVERIES: PROJECTS, STRATEGIES AND DEVELOPMENT»

OCTOBER 25, 2019

VOLUME 3

Edinburgh • Scotland, UK 
S 30

Chairman of the Organizing Committee: Holdenblat M.

Responsible for the layout: Kazmina $\mathrm{N}$.

Responsible designer: Bondarenko I.

S 30 Scientific discoveries: projects, strategies and development: Collection of scientific papers "^ОГО $\Sigma$ » with Proceedings of the International Scientific and Practical Conference (Vol. 3), October 25, 2019. Edinburgh, UK: European Scientific Platform.

ISBN 978-617-7171-83-5

DOI 10.36074/25.05.2019.v3

Papers of participants of the International Multidisciplinary Scientific and Practical Conference «Scientific discoveries: projects, strategies and development», held in Edinburgh, October 25, 2019, are presented in the collection of scientific papers.

The conference is included in the catalog of International Scientific Conferences, approved by ResearchBib and certified by Euro Science Certification Group (SCC-2000).

Conference proceedings are publicly available under terms of the Creative Commons Attribution 4.0 International License (CC BY 4.0).

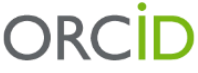

Connecting Research and Researchers

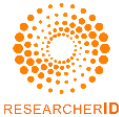

RESEARCHERID
Bibliographic descriptions of the conference proceedings are available for indexation by ORCID, Publons, Google Scholar, ets.

(C) Participants of the conference, 2019 


\section{CONTENT}

\section{SECTION XI. PHILOLOGY}

DATA MINING APPLICATIONS IN UKRAINE

Yurchenko I.

INTERMEDIALITY, MULTIMODALITY AND INTERMODALITY IN MODERN LINGUISTICS

Vorobiova M.

ЕТИМОЛОГІЯ КОНЦЕПТУ «WАSTЕ»

Стрюк Є.В.

ФОРМУВАННЯ УЧНЯ-ПАТРІОТА НА УРОКАХ УКРАЇНСЬКОЇ МОВИ ТА ЛІТЕРАТУРИ

Козова Н.А.

РОЗВИТОК ТЕОРІЇ ТЛУМАЧНОЇ ЛЕКСИКОГРАФІЇ У СЕРБСЬКІЙ ЛІНГВІСТИЧНІЙ НАУЦІ ХІХ - XX СТ.

Ілясов 0.0.

СЕМАНТИЧНІ ВІДМІННОСТІ ТА СПОСОБИ ПЕРЕКЛАДУ АНГЛІЙСЬКИХ ПАРАМЕТРИЧНИХ ПРИКМЕТНИКІВ НUGЕ ТА GREAT (HА MATEPIAЛI ФІЛЬMIB КАНАЛУ ВВС THE BLUE PLANET TA LIFE)

Береговенко Н.С.

ХУДОЖНЄ ОПРИЯВЛЕННЯ СОЦІАЛЬНИХ ВИКЛИКІВ У ТВОРАХ БАРБАРИ КОСМОВСЬКОї

Мартинець А.M.

\section{SECTION XII. POLITICS}

ПРИЧИНИ ТА ШЛЯХИ ПОДОЛАННЯ АБСЕНТЕЇЗМУ ЄВРОПЕЙСЬКОЇ МОЛОДІ

Махно К.O.

ПРО ВПЛИВ ГЛОБАЛІЗАЦІЇ НА ЗМІНУ ЗМІСТУ ФУНКЦІЙ СУЧАСНИХ ДЕРЖАВ

Музиченко Г.В. 
4 - Scientific discoveries: projects, strategies and development $\bullet$ Volume 3

\section{SECTION XIII.}

\section{LAW}

MìNEACHAIDHEAN TEICNEÒLAS LAGHAIL CO-CHUNNTAS ANN AN ALBA

Maksurov A.

PROTECTION OF PROPERTY RIGHTS IN THE AREAS OF CONDUCTING UNITED FORCES OPERATION

Lychenko I.

АКТУАЛЬНІ ПИТАННЯ ІНСТИТУТУ ЕЛЕКТРОННИХ ДОКАЗІВ В ЦИВІЛЬНОМУ ПРОЦЕСІ

Шостак Ю.О.

ВПЛИВ ПРОЦЕСІВ ГЛОБАЛІЗАЦІЇ НА МІЖНАРОДНЕ ПРИВАТНЕ ПРАВО

Махно К.О.

ДО СТАНУ РОЗРОБКИ ПРОБЛЕМИ АЛЬТЕРНАТИВНИХ ЗАСОБІВ РОЗВ'ЯЗАННЯ КРИМІНАЛЬНО-ПРАВОВОГО КОНФЛІКТУ

Сімонцева Л.О.

ЗАСТЕРЕЖЛИВІ ЗАУВАЖЕННЯ ЩОДО ПРОЦЕСУ ДЕСОЦІАЛІЗАЦІЇ У СВІТІ ПРАЦІ

Гладкий В.В.

ЗУСТРІЧНЕ ЗАБЕЗПЕЧЕННЯ ПОЗОВУ В ЦИВІЛЬНОМУ ПРОЦЕСІ

Гердова К.О.

ІМПЛЕМЕНТАЦІЯ ЄВРОПЕЙСЬКОГО ПРАВА В НАЦІОНАЛЬНЕ ЗАКОНОДАВСТВО УКРАЇНИ

Левкович І.В.

ЛІНІЯ ЗАХИСТУ ЩОДО НЕЗАКОННОГО ЗВІЛЬНЕННЯ

Чепіга Д.О.

О ПОНЯТИЕ ЭКОЛОГИЧЕСКОЙ ИНФОРМАЦИИ

Мальчик О.Н.

ОКРЕМІ ПИТАННЯ ЦИВІЛЬНОÏ ПРАВОСУБ'ЄКТНОСТІ

НЕПІДПРИЕМНИЦЬКИХ ТОВАРИСТВ

Гелецька I.O.

ОСОБЛИВОСТІ ПРАВОВОГО СТАТУСУ ТВАРИН В УКРАЇНІ Лопацька Ю.В. 
October 25, 2019 • Edinburgh, Scotland, UK • 5

ПАПІЛЯРНІ ЛІНІЇ: ОСНОВНИЙ КЛЮЧ ДО РОЗКРИТТЯ ЗЛОЧИНІВ Махно К.О.

ПЕРСПЕКТИВИ ЗАПРОВАДЖЕННЯ ЕЛЕКТРОННОГО НОТАРІАТУ В УКРАЇНІ

Гердова К.О.

ПЕРСПЕКТИВИ ПЕРЕХОДУ ЦИВІЛЬНОГО СУДОЧИНСТВА В УКРАЇНІ У ПРИВАТНИЙ СЕКТОР

Махно К.O.

ПЕРСПЕКТИВИ ТА ПРОБЛЕМИ КОНЦЕПЦІЇ ЕЛЕКТРОННОГО КРИМІНАЛЬНОГО ПРОВАДЖЕННЯ В УКРАЇНІ

Абражевич Д.А.

ПОДВІЙНЕ ГРОМАДЯНСТВО В УКРАЇНІ: ПРОБЛЕМНІ АСПЕКТИ

Гердова К.О.

ПОРІВНЯЛЬНИЙ АНАЛІЗ ПРОТИДІЇ ПОЛІТИЧНІЙ КОРУПЦІЇ В КРАЇНАХ ЄВРОПЕЙСЬКОГО СОЮЗУ ТА УКРАЇНІ

Данченко К.М., Широкова А.А.

ПРАВОВА ПРИРОДА РЕЄСТРІВ НОТАРІАЛЬНИХ ДІЙ

Єлізаренко К.Х.

ПРАВОВЕ ЗАБЕЗПЕЧЕННЯ ФІНАНСОВОЇ БЕЗПЕКИ

Храпкіна В.В., Стратонов В.М.

ПРАВОВЕ РЕГУЛЮВАННЯ ТРУДОВОЇ ДОПОМОГИ БЕЗРОБІТНИМ В УСРР В ПЕРІОД НОВОЇ ЕКОНОМІЧНОЇ ПОЛІТИКИ (1921-1929 рр.)

Харасик Н.O.

ПРАВОВІ ЗАСАДИ САМОРЕГУЛЮВАННЯ СУСПІЛЬНИХ ВІДНОСИН В ІНФОРМАЦІЙНІЙ СФЕРІ УКРАЇНИ

Маріц Д.О.

ПРЕЗИДЕНТ УКРАЇНИ, ЙОГО РОЛЬ ТА МОЖЛИВІСТЬ УСУНЕННЯ З ПОСАДИ В ПОРЯДКУ ІМПІЧМЕНТУ

Кривульський Д.С.

ПРО СУТНІСТЬ ОЗНАК, ЩО ХАРАКТЕРИЗУЮТЬ ЮРИДИЧНИЙ ФАКТ

Остапенко Л.О.

ПРОБЛЕМНІ АСПЕКТИ ДОТРИМАННЯ НОТАРІАЛЬНОЇ ТАЕМНИЦІ

Шостак Ю.О. 
6 - Scientific discoveries: projects, strategies and development $\bullet$ Volume 3

РОЗВИТОК КОНСТИТУЦІОНАЛІЗМУ В УКРАЇНІ

Левкович І.В.

СИСТЕМНІСТЬ ТА НОРМАТИВНІСТЬ У ПРАВІ: ДІАЛЕКТИКА ВЗАЄМОДії

Андрощук A.P.

СПІВРОБІТНИЦТВО ДЕРЖАВ У БОРОТЬБІ ІЗ ЗЛОЧИННІСТЮ

Перерва А.O.

СПОСОБИ БОРОТЬБИ З АБСЕНТЕЇЗМОМ В ЄВРОПЕЙСЬКИХ KPAÏHAX

Шостак Ю.О.

ТОРГІВЛЯ ЛЮДЬМИ: КРИМІНОГЕННІ ДЕТЕРМІНАНТИ ТА ЗАХОДИ ПРОТИДІЇ В УКРАЇНІ

Науково-дослідна група:

Томчук I.O., Денисовський М.Д., Томчук I.O.

ТРАНСФОРМАЦІЯ ІНСТИТУТУ ДЕРЖАВНОЇ РЕЕСТРАЦІЇ РЕЧОВИХ ПРАВ НА НЕРУХОМЕ МАЙНО В УКРАЇНІ В УМОВАХ СЬОГОДЕННЯ

Німак М. О., Андрусів I.T.

\section{SECTION XIV. HISTORY}

ПРОЦЕС АНТИРАДЯНСЬКОЇ АКТИВНОСТІ В УКРАЇНСЬКОМУ СЕЛІ НА ЗЛАМІ 1920-1930-Х РОКІВ ЯК СЕГМЕНТ НАРОДНОГО ОПОРУ СТАЛІНСЬКІЙ МОДЕРНІЗАЦІЇ СУСПІЛЬСТВА

Мотуз В.К.

\section{SECTION XV. GEOGRAPHY}

БІОКЛІМАТИЧНІ ПОКАЗНИКИ ПОЛТАВСЬКОЇ ОБЛАСТІ

Рибчан B.C. 118

ГЕОГРАФІЯ ЗВУКОВИХ ЛАНДШАФТІВ ПОЛТАВСЬКОЇ ОБЛАСТІ Демченко P.I. 
АНАЛІЗ СПОСОБІВ ПОСИЛЕННЯ ЗАЛІЗОБЕТОННИХ БУДІВЕЛЬНИХ КОНСТРУКЦІЙ

Ігнатьєва В.Б., Шинкляр Н.В.

ОСНОВНІ НАПРЯМКИ ЗАСТОСУВАННЯ ВЕЧІРНЬОГО І НІЧНОГО ОСВІТЛЕННЯ ПРИШКІЛЬНИХ ТЕРИТОРІЙ

Коваль Л.М.

ФУНКЦІЇ СЕНСОРНИХ ТЕХНОЛОГІЙ В ДИЗАЙНІ ІНТЕР'ЄРІВ ЗАГАЛЬНООСВІТНЬОÏ ШКОЛИ

Катріченко К.О. 
8 - Scientific discoveries: projects, strategies and development $\bullet$ Volume 3

\section{SECTION 11. \\ PHILOLOGY}

\section{DATA MINING APPLICATIONS IN UKRAINE}

\section{Yurchenko Iryna}

arts student

Admiral Makarov National University of Shipbuilding

Scientific advicer: Dubova Olena

Ph.D., Professor, head of the Department of Applied Linguistics

Admiral Makarov National University of Shipbuilding

UKRAINE

Over the past 50 years, electronic communications have become part of the current system of life, though to the continuous growth of information and communication technologies. Taking into account the processes of globalization that occur in the world, as well as Ukraine's aspirations for European integration, it is noteworthy that aspects of achieving the desired pragmatic and communicative effect during translation for a multicultural audience are of special importance. One of such aspects is Data mining, which is being at the stage of its active development in Ukraine.

A great contribution to Data mining area was made by computer scientist Richard Socher with his investigation on Neural Analysis of Sentiment in collaboration with Stanford computer science professors Christopher Manning and Thang Luong. However, they all focus more on issues of the English language. The given paper is aimed at defining the concept of pragmatic aspect of Data mining based on the Ukrainian language usage.

Ian $\mathrm{H}$. Witten and Eibe Frank, famous researchers working in the sphere of machine learning, have defined Data mining as the process of discovering patterns in data. They stressed out that: "Data mining is the extraction of implicit, previously unknown, and potentially useful information from data. The idea is to build computer programs that sift through databases automatically, seeking regularities or patterns." [1].

It seems obvious to us that Ukrainian researchers should intend to implement an automatic system of linguistic analysis of the text, based on the experience of Stanford computer scientists. A Ukrainian system based on a similar algorithm that is being developed at Stanford University, should be focused on the analysis of Ukrainian-language texts [2]. To our mind, the task of developing a system may be as follows: to take into account the specifics of the Ukrainian language and automatically understand the meaning of texts written by people in order to determine the emotional coloring of messages, process neologism words and much more.

Therefore, to complete the task system should consist of three main modules. The first module should contain basic text analysis algorithms that may be useful to linguistic researchers. By the basic algorithms, they understand determining 
the language of the text, breaking the text into sentences, parsing, correcting spelling errors and typos.

The second module should focus on extracting information from texts. For example, using this module one can select a specific person from several namesakes, even if only the surname is indicated in the text. The function of highlighting the "key entity", which a particular person or a certain place may relate to, allows you to choose from the set of found values those that are most significant for a given text.

The third module must include algorithms for analyzing the emotional coloring of the text as a whole. The module is needed for working with social networks and should be applied to short or detailed comments, reviews.

In conclusion, aspect of Data mining applications in Ukraine presents an issue that is vitally important for the investigation of creating machine-based systems that can learn and think without carefully specified directions.

\section{Refernces:}

1. Witten, I. H., \& Frank, E. (2016). Data Mining: Practical Machine Learning Tools and Techniques, ( $4^{\text {th }}$ ed.). Burlington: Morgan Kaufmann Publishers.

2. Luong. T., Socher. R., \& Manning. C. (2013). Better Word Representations with Recursive Neural Networks for Morphology. Proceedings of the Seventeenth Conference on Computational Natural Language Learning: Shared Task, (17), 104-113. Retrieved from https://www.aclweb.org/anthology/W13-3512.pdf.

DOI 10.36074/25.10.2019.v3.01

\section{INTERMEDIALITY, MULTIMODALITY AND INTERMODALITY IN MODERN LINGUISTICS}

Maryna Vorobiova

Ph.D. in Linguistics (Germanic Languages), Associate Professor at the Department of English Translatology Zaporizhzhia National University

UKRAINE

Nowadays due to the fast-paced process of digitalization it is common among the researchers to speak about three types of texts: lingual (verbal), extralingual (non-verbal) and mixed; sometimes it is stated that a word is replaced by an image [7]. But in our study we will try to focus on verbal texts and their ability to appeal to different sensorial experience through words, without applying images or audiovisual elements.

Earlier we concentrated more on the theory of intermediality, as a scientific approach. But with the appearance of multimodality and the creation of the definition of one of its core notions, a "mode", which is often opposed to a "medium", we suppose that there is an urgent need to clarify the difference and to find out which 
of the approaches is more relevant while studying the ability of a verbal text to incorporate information originally presented by means of a non-verbal semiotic system.

We understand "medium" as a material or substance that bears a sign that contains information (like a printed book, a storage device with audio or video file etc.) $[2,4,6]$. Therefore, "intermediality" is understood as intertextuality that goes beyond one medium [3].

As for "mode", it is an outcome of the cultural shaping of a particular resource through its use in the daily social interaction of people [1]. In order for a particular resource to be a mode, the community in which it is used needs to recognise it as a mode and share a cultural sense of how this resource can be organised to construct and convey meaning [4]. The term "mode" still remains rather vague, it is sometimes equalled to the term "mode of communication" and in Ukrainian linguistic tradition the offered equivalents are "модус", "план", "режим" [5]. We understand a mode as a source of extralingual information of a certain cultural value for the representatives of a certain society.

A mode is a key notion of multimodal studies, in the framework of which it is assumed that communication always involves the use of multiple modes (speech, writing, gestures, images, and others), and their intermodal relationships contribute to meaning-making [4]. One should stress that here the term "intermodal" refers to the relations between different modes present in one text (between an image and a text on a poster etc.), and it also belongs to key notions of multimodality.

As for our research, we suggest to introduce the notion of "intermodality" meaning the relations that arise between a verbal text and non-verbal texts that the former refers its recipients to. In this context the term "intermodal relations" will still mean the relations between different modes, but not those that a recipient can perceive at once with the verbal text, but those which are present in his/her previous experience.

It's our firm belief that for our research the term "intermodality" is more relevant than the term "intermediality", because one and the same media may bear the source (the mode) of different semiotic type (e. g. both verbal texts and images can be found on paper; modern digital media can bear visual, audio, audiovisual texts etc.). It is vital to underline that we focus on revealing the key features of relation between the texts created by means of different semiotic codes, not between the media they are stored on.

1. Bezemer, J. (2012). What Is Multimodality? Retrieved from: https://mode.ioe.ac.uk/2012/02/16/what-is-multimodality/.

2. Kress, G. \& van Leeuwen, T. (2001). Multimodal Discourse: the Modes and Media of Contemporary Communication. London: Arnold.

3. Lehtonen, M. (2001). On No Man's Land: Theses on Intermediality. Nordicom Review, (1), 71-83. Göteborg: Göteborgs universitet.

4. Lyons, A. (2016). Multimodality. Research Methods in Intercultural Communication: A practical guide. Wiley-Blackwell. 268-280. DOI: 10.1002/9781119166283.ch18.

5. Андрєєва І. О. (2016). Мультимодальний аналіз дискурсу: методологічна основа та перспективи напряму. Одеський лінгвістичний вісник, (7), 3-8. 
6. Луман, Н. (2005). Медиа коммуникации. М.: Издательство «Логос».

7. Омельяненко, В. А., Ремчукова, Е. Н. (2018). Поликодовые тексты в аспекте теории мультимодальности. Коммуникативные исследования, 3 (17), 66-78. DOI: 10.25513/24136182.2018.3.66-78.

\section{ЕТИМОЛОГІЯ КОНЦЕПТУ «WASTE»}

Стрюк Євгенія Володимирівна

старший викладач кафедри українознавства та іноземних мов Дніпропетровський державний університет внутрішніх справ

УКРӒ̈HA

Аналізуючи проблеми виявлення національної специфіки англійської мови за З. Д. Поповою та І.А. Стерніним, під терміном «концепт» в статті розуміється «квант структурованого знання» - семантична категорія найбільш високого ступеня абстракції, що включає в себе приватні значення конкретизації загальної семантики окремого поняття. Не порушуючи основного сенсу терміну «концепт», він розглядається як сукупність семантичних одиниць культурної спеціалізованої області, що відображають певну специфріку світосприйняття носіїв мови [1]. Виділення концепту «шаste» $є$ важливим, так як науковий концепт дає уявлення про наукове понятійному апарату. Оскільки методика опису наукових концептів знаходиться в стадії розробки, введення будь-якого нового матеріалу для опису структури наукового концепту буде своєчасним і актуальним [2].

Визначимо наші позиції щодо виділення концепту «waste». Концепт як ментальна одиниця традиційно описується через аналіз засобів його мовної об'єктивації, отже, побудова номінативного поля наукового концепту являє собою встановлення та опис сукупності мовних засобів [3]. Зважаючи на неоднорідності номінативного поля завжди виникає проблема його коректного структурування. У побудові номінативного поля концепту «waste» ми не обмежувалися прямими номінаціями, а виявляли все доступне номінативне поле концепту, включаючи номінації різновидів його денотатів, для чого нами були встановлені ключові терміни-репрезентанти - лексичні одиниці, які об'єктивно представляють реальну процедуру консервації відходів збагачення корисних копалин. Так, терміном-репрезентантом концепту «waste» $\epsilon$ термін «відходи» на підставі його частотного вживання в аналізованих теоретичних джерелах. Через синонімічне розширення ключового терміну було визначено ядро номінативного поля: для терміну «відходи» це «хвости», «шлам», «шлак», «розкривні породи», «вміщують породи» [4].

Наступним кроком в описі структури концепту стало визначення його ознак на підставі аналізу дефрініції терміну. Термін «відходи» означає «продукти з малим вмістом цінних компонентів, подальше вилучення яких неможливо технічно чи недоцільно економічно» [5]. 3 визначень видно, що ядерні компоненти терміну «відходи» представлені в таких поняттях як 'продукт', 'нецінний продукт', 'відсутність користі', 'побічний продукт' [6]. Аналіз визначень 
терміну «відходи» дозволяє говорити про семантичної опозиції: з одного боку, це побічний продукт виробництва з різними технічними характеристиками, 3 іншого - це побічний продукт, придатний для подальшого використання в промисловості. Така опозиція значень, закладена в одному терміні, може говорити про те, що в ньому поєднуються різні ознаки: з одного боку, це побічний продукт, з іншого - цінна речовина, отримана після переробки відходів. Таким чином, даний концепт характеризується наступними концептуальними ознаками: «продукт виробництва», «технічні характеристики продукту» і «повторне застосування відходів».

Висновки. У результаті аналізу можна говорити про те, що концепт здатний не тільки відображати структуру організації певної сфери діяльності, а й фріксувати отримані людиною знання, тому його можна розглядати як «дзеркало» наукової картини світу. При цьому не слід забувати, що когнітивна модель світу, що є реальною репрезентацією людських знань і діяльності, існує у вигляді певної системи понять, а мовна модель світу не паралельна когнітивній, а вбудована в ній в якості підсистеми. У семантиці аналізованого концепту простежуються процеси людського осмислення навколишньої дійсності. Осмислюючи об'єкти і явища навколишньої дійсності, людина категоризує наукову картину світу в своїй свідомості на підставі тих знань, якими він розпоряджається. Інтерпретація наукової картини світу трансформується в певну форму мови і семантику цієї форми. Враховуючи роль категоризації та концептуалізації в процесі номінації, можна стверджувати, що наукова картина світу антропоцентрична, оскільки відображає особливості національного світосприйняття і категоризації реального світу, а вербалізація цього світу обумовлена етнічною мовною формою.

\section{Список використаних джерел:}

1. Попова, 3. Д. \& Стернін, І. А. (2010). Деякі проблеми виявлення національної специфіки мови. Воронеж: Видавництво Воронезького державного університету. [in Russian].

2. Слишкін, Г. Г. (2000). Від тексту до символу: лінгвокультурні концепти прецедентних текстів у свідомості «дискурсу». Москва: Видавництво Азбуковник. [in Russian].

3. Стернін, І. А. (2001). Методика дослідження структури концепту // Методологічні проблеми сучасної лінгвістики. Воронеж: Видавництво Воронезького державного університету. [in Russian].

4. Апресян, Ю. Д., Ботякова, В. В. \& Латишева, Т. Е. (2014). Англо-російський синонімічний словник. Москва: Видавницво Медіа. [in Russian]

5. Edinburgh Gate. (2005). Longman Dictionary of English language and Culture.

6. Cambridge. (2007). Cambridge Learner's Dictionary. 


\section{ФОРМУВАННЯ УЧНЯ-ПАТРІОТА НА УРОКАХ УКРАЇНСЬКОÏ МОВИ ТА ЛІТЕРАТУРИ}

Козова Неоніла Андріївна

вчитель української мови та літератури, вчитель-методист Черкаської загальноосвітньої школи I-III ступенів № 25,

Черкаської міської ради Черкаської області

УКРАÏHA

Серед десяти пріоритетів визначених МОН на 2019 рік щодо нової української школи $€$ виховання молодих громадян. В основоположних нормативних документах, які окреслюють головні напрямки розвитку й вдосконалення загальної середньої освіти, завдання виховання громадянина висунуті на перший план. У Державному стандарті базової загальної середньої освіти з української мови першочерговою стратегічною метою ії̈ вивчення $€$ виховання патріотизму, любові та свідомого ставлення до неї як до духовної цінності, засобу спілкування й отримання знань у різних сфрерах людської діяльності. Стосовно української літератури, то її вивчення в школі також вважається необхідною умовою виховання духовно розвиненої особистості, формування гуманістичного світогляду, почуття патріотизму, любові й поваги до цінностей вітчизняної культури [4].

Мета наукової розвідки: розкрити сутність і значення процесу патріотичного виховання на уроках української мови та літератури.

Об'єкт дослідження: патріотичне виховання в школі.

Предмет вивчення: формування учня-патріота на уроках української мови та літератури.

Історіографрія теми. Аналіз останніх досліджень і публікацій [1-3, 5], в яких розглядалися аспекти цієї проблеми та на які спирається авторка даної наукової розвідки, свідчать про те, що тема патріотичного виховання на уроках української мови та літератури $€$ актуальною і вимагає повного, всестороннього та аргументованого висвітлення.

Вчителям української мови та літератури необхідна систематична робота у вищезазначеному напрямку, адже саме від зростання свідомості та соціальної активності громадян України, перш за все молоді, значною мірою залежить формування в нашій країні громадянського суспільства й правової держави.

Тому сьогодні, як ніколи, актуальні слова В. Симоненка:

«Можна все на світі вибирати, сину,

Вибрати не можна тільки Батьківщину» [6].

На жаль, існує ілюзія, що якщо докладно пояснити дітям і підліткам, що таке добро, а що - зло, то останні відразу стануть хорошими. Повчальність і звернення лише до логіки молодої людини, - типові помилки в підході до вирішення завдань патріотичного виховання. Але, як показала практика, тільки слово забарвлене щирим почуттям може дати необхідний виховний результат.

Пізнавальна цінність української мови, як навчального предмета, надзвичайно висока: на таких уроках фрормується мислення, прищеплюється почуття любові до Вітчизни, рідного краю, через мову осмислюються 
загальнолюдські цінності, виховується особистість, за ії допомогою відбувається інтелектуальний розвиток учня та засвоєння ним всіх інших шкільних дисциплін [3].

У змісті даного предмета два типи навчального матеріалу, які можна використовувати з метою виховання. По-перше, це загальні відомості про мову, а по-друге - дидактичні матеріали: вправи підручника, навчальні диктанти, перекази, твори, тексти для комплексного аналізу й т. п. [5].

3 огляду на специфіку предмета, у процесі виховання патріотизму на уроках української мови використовуються наступні методичні прийоми: написання творів на патріотичні теми; попутні роз'яснення вчителя, що розкривають патріотичний зміст текстів вправ підручника; фронтальна бесіда, яка допоможе краще висвітлити теоретичний аспект теми, на яку учнівська молодь буде писати твір [1].

Відповідний процес вимагає акцентування уваги на тих думках і почуттях, які формують патріотизм у дітей та підлітків й повинні бути відображені у складанні речень і тексту, наприклад: «Як проявляють хоробрість воїни ООС, їх вірність Батьківщині?» або «Чи могли б Ви вчинити так само?».

Українська література як освітній предмет, несе в собі багатий навчальний матеріал, який сприяє патріотичному вихованню учнів: біографрічні відомості видатних українських письменників і поетів; твори, які розкривають історичні етапи розвитку нашої держави та її культури, довгий і складний шлях українського народу до утвердження своєї самобутності; тексти художніх творів й публіцистики тощо [2].

Написання учнівською молоддю доповідей та рефератів, їх участь у диспутах і дискусіях дають можливість вчителю української мови та літератури судити про рівень впливу досліджуваних творів на формування національних цінностей та виховання патріотичних почуттів у дітей та підлітків, а останнім глибше усвідомити свої погляди й судження, знайти обґрунтування їм, висловлювати свої думки про Вітчизну, про її шлях і про людей, які мужньо та стійко переносили життєві тяготи, але не зійшли з нього. Учні поступово дорослішають і усвідомлюють себе причетними до цього шляху [5].

Напевно, не варто стверджувати, що діти, вийшовши з уроку української мови чи літератури, відразу ж стануть справжніми патріотами, але якщо він залишив хоч незначний слід в їх душі, то урок досяг своєї мети.

Висновки. Патріотичне виховання молодого покоління $є$ першочерговим завданням для громадянського суспільства та держави, які поклали на педагогічних працівників відповідальну місію: на чистому аркуші дитячих душ вписати найпотрібніші слова, вкласти в голови учнів найважливіші думки.

По-справжньому незамінними помічниками для них у цьому непростому процесі є вчителі української мови та літератури, які за шкільні роки мають встигнути познайомити учнівську молодь 3 багатством і різноманітністю української мови, показати красу й багатогранність вітчизняної літератури та прищепити молодому поколінню любов до Батьківщини та рідного краю.

\section{Список використаних джерел:}

1. Кравець, Н. \& Палагнюк, О. (2017). Формування почуття патріотизму на уроках української літератури. Молодий вчений, (3/43), 398-401. 
2. Лагода, К. (2016). Формування національно-патріотичної свідомості учнів на уроках української літератури. Таврійський вісник освіти, (4), 114-120.

3. Пентилюк, М. (2007). Сучасний урок української мови. Харків: «Основа».

4. МОН розробило новий державний стандарт базової середньої освіти. Вилучено 3 https://nus.org.ua > news > mon-rozrobylo-novyj.

5. Сидоренко, В. (2015). Українська мова та література. 5-11 класи: методичні рекомендації щодо організації навчально-виховного процесу в 2015-2016 н. р. 3 коментарем провідних фахівців. Харків: Ранок.

6. Симоненко, В. (2008). Вибране: [вірші, казки, оповід.]: для серед. та шк. віку. Г. Кирпи \& Д. Чередниченка (упоряд., комент., прим.). Київ: «Школа».

DOI 10.36074/25.10.2019.v3.02

\title{
РОЗВИТОК ТЕОРІЇ ТЛУМАЧНОЇ ЛЕКСИКОГРАФІЇ У СЕРБСЬКІЙ ЛІНГВІСТИЧНІЙ НАУЦІ ХІХ - XX СТ.
}

\author{
Ілясов Олександр Олександрович \\ викладач кафедри слов'янського мовознавства \\ ПНПУ імені К.Д. Ушинського \\ УКРӒ̈НA
}

Крім постаті основоположника сербської літературної мови нового часу Вука Караджича, серед сербських лінгвістів XIX ст. варто виділити кількох учених, які зробили значний вклад у становлення i розвиток сербськохорватської лексикографії.

Першим з них слід назвати ім'я молодшого соратника Вука, видатного сербського і хорватського філолога Джури Даничича. Дж. Даничич практично не залишив після себе значних праць з теорії лексикографії, однак його погляди на теорію і практику укладання словників відбито у кількох лексикографічних проектах, автором чи учасником яких він був. Серед них особливої уваги заслуговують три: підготовка другого видання «Српског рјечника» Вука Караджича (1852), укладання самим Дж. Даничичем «Речника из књижевних старина српских» (1863-64) та участь як головного редактора у підготовці та публікації перших двох томів «Рјечника хрватског или српског језика» Південнослов'янської академії науки та мистецтва (1880-1882).

Позиція Даничича щодо тлумачної лексикографії чітко окреслилась вже при підготовці до друку другого видання «Српског рјечника» Вука Караджича. У багатьох питаннях погляди Вука і Даничича не збігалися. Суперечності між ними виявилися, перш за все, при виробленні концепції майбутнього словника; вони стосувалися проблеми макроструктури словника - корпусу слів, які повинні були ввійти до його реєстру. За словами М. Поповича [5], Вук хотів створити словник живого мовлення сербів, тобто лексикон тих слів, які він сам чув або їх записали інші, словник народної говірки, який би віддзеркалював сам народ, його національно-етнічний характер, культуру, дух. У свою чергу, 
Дж. Даничич схилявся до думки, що це має бути словник сербсько-хорватської мови, у який ввійдуть всі слова - живі і забуті, сказані і написані.

Таким чином, вже в 50-х роках XIX століття погляди Дж. Даничича на практичні завдання сербсько-хорватської лексикографії носили комплексний, діахронічний характер. Єдиним прийнятним варіантом тлумачного словника для нього вже тоді був тезаурус національної мови, тобто словник-скарбниця, який би ввібрав усе багатство усного і писемного народного мовлення. Ця концепція повною мірою була втілена у роботі Дж. Даничича над «Рјечником хрватског или српског језика» Південнослов'янської академії науки i мистецтва.

Своєрідною сходинкою до створення цього словника став укладений Даничичем перший історичний словник сербсько-хорватської мови «Рјечник из књижевних старина српских» (1863 - кн. I і II, 1864 - кн. III), про що свідчить оцінка цієї праці сербськими лінгвістами того часу. Так, видатний сербський філолог кінця XIX - початку XX століття Стоян Новакович, високо оцінивши цей словник як «глибоко продуманий, створений 3 надзвичайною точністю, сумлінністю і працьовитістю», вважав, що «прірва, яка близько п'ятдесяти років пролягала між старою сербською літературою і віком теперішнім, цією працею враз заповнена, і сербська сучасність пов'язана зі своїм минулим» [3].

Практично «Рјечник из књижевних старина српских» Дж. Даничича став своєрідним історичним доповненням «Српског рјечника» Вука Караджича, який відбивав сучасний (на період свого створення - середину XIX ст.) етап розвитку сербського народної мови.

У свою чергу «Рјечник хрватског или српског језика» Південнослов'янської академії науки і мистецтва, об'єднав зміст Вукового «Српског рјечника» і Даничичевого «Рјечника из књижевних старина српских», доповнивши їх склад із нових джерел.

Історична спрямованість Академічного словника зумовила, зрештою, характер усіх його макро- і мікроструктурних елементів. Наприклад, при тлумаченні багатозначного слова Даничич як «основне значення» подавав історично первісне, «ембріональне» значення [8].

У сербській лінгвістиці кінця XIX - початку XX ст. виділяється постать відомого фрілолога Стояна Новаковича, основоположника сучасної сербської академічної лексикографії [7].

Стоян Новакович має великі заслуги у розвитку сербського словникарства. В історії сербської лексикографії він відомий передусім як ініціатор підготовки та видання словника-тезаурусу «Речник народнога књижевног језика српског», - майбутньої капітальної праці, яка більш ніж через 50 років буде публікуватися під назвою «Речник српскохрватског књижевног и народног језика» (перша книга була видана в 1959 р.), а також як засновник Лексикографічного відділу Сербської королівської академії (зараз це Інститут сербської мови САНУ).

Основи формування сучасної сербської лексикографії Стоян Новакович виклав у «Посланні Академії наук філософських» [3], а надалі уточнив та доповнив у «Пропозиції Сербської Королівської Академії» (1893) [4].

Новакович відчував потребу в новому словнику, який би встановлював зв'язок з попередніми лексикографрічними працями і включав би їх лексику, а також, що безумовно важливо, містив слова, які з'явилися «в новій 
інтелектуальній творчості». Він вважав, що це буде словник «народної літературної мови», тобто літературної мови на народній основі, в дусі Вука Караджича і запропонованих ним принципів лексикографії. Стоян Новакович стверджує, що реєстр нового словника має вмістити попередні сто років літературного життя [3]. До нього, перш за все, має ввійти лексика народних говірок, а також весь той лексичний масив, що охоплює Вуків «Српски рјечник», але у більш систематизованому вигляді. Новий словник мав би стати вичерпним зібранням лексики з усіх сфер народного життя. Крім того, за задумом Новаковича, до словника обов'язково повинен бути залучений матеріал із художніх творів та книг - від Доситея Обрадовича до сучасності, написаних «народною літературною мовою», а також матеріал із різних словників (Б. Шулека, Дж. Поповича та ін.), у яких знайшлося б «дещо, взяте і 3 самої народної мови або створене за законами мови» [3]. Така лексикографрічна праця була задумана як нормативний словник-скарбниця, поповнення якого відбувалось би без порушення основних вуківських принципів. Створення словника-скарбниці, на думку Новаковича, призвело б до остаточного утвердження нової сербської літературної мови.

Отже, узагальнюючи, можна сказати, що основні питання теорії лексикографії, які були порушені в працях найбільш відомих сербських лексикографрів XIX ст., - це проблеми макроструктури словника, принципів добору лексичного матеріалу для словника. На наш погляд, орієнтація вчених на ці проблеми була зумовлена тим, що сербська літературна мова нового часу перебувала у стадії формування, і питання її лексичного нормування вимагали свого якнайшвидшого розв'язання.

Невипадково у теоретичних працях сербських лексикографрів другої половини XX століття (періоду, коли сербська літературна мова уже сформувалася, розвинула систему стилів) частіше порушуються проблеми мікроструктури словника.

Можна стверджувати, що найбільша увага в сербській теоретичній лексикографрії кінця $\mathrm{XX}$ століття приділяється двом основним проблемам: 1) питанням стилістичної характеристики лексики і 2) питанням лексикографічного опису семантики слова.

Щодо першої групи питань варто виділити зіставне дослідження Боголюба Станковича «Стилистичке информације у речницима српског и руског језика» [6], де автор, шляхом порівняння російських і сербських тлумачних словників різних типів, виявляє недоліки стилістичної характеристики, прийнятої в сербській тлумачній лексикографії. Одним з основних недоліків стилістичної характеристики слів у тлумачних словниках сербсько-хорватської мови Б. Станкович справедливо вважає відсутність функціонально-стилістичних позначок, які диференціюють лексичний матеріал 3 точки зору його співвіднесеності з одним із функціональних стилів, що пояснюється в цілому недостатнім опрацюванням в сербістиці загальних питань стилістичного членування мови.

Найбільш цікавими серед сербських праць, присвячених теорії і практиці лексикографрії, $€$ дослідження, присвячені лексичній семантиці і пов'язані зі словниковими дефініціями. Важлива в цьому плані книга Даринки ГортанПремк «Полисемија и организација лексичког система у српскоме језику» [1]. 
У цій роботі, окрім багатозначності лексеми, аналізуються й інші питання семасіології, які стосуються організації лексичної системи. Разом із тим книга $\epsilon$ не лише теоретичним дослідженням. У зв'язку 3 вищезгаданими теоретичними проблемами у ній і пропонуються нові та описуються існуючі практичні лексикографічні рішення. Ці рішення і пропозиції призначені, перш за все, для вдосконалення Словника САНУ і роботи над ним з позицій сучасного стану розвитку лексикографії.

Наприклад, у зв'язку з питаннями полісемії Д. Гортан-Премк розглядає характеристику дефініції у тлумачному словнику. Тлумачна частина дефрініції основного значення слова (первинна семантична реалізація), на її думку, обов'язково повинна містити семи, релевантні для розвитку полісемантичної структури. Так, наприклад, в Словнику САНУ в дефініції лексеми зуб не приводиться сема "білизна", хоча це є дуже важливою для повсякденного життя особливістю зуба. I все ж, Д. Гортан-Премк пропуск цієї семи вважає коректним лексикографічним вчинком, бо ця сема не $є$ продуктивною в розвитку полісемантичної структури лексеми зуб. Тут спостерігається невідповідність мовної логіки та логіки повсякденного життя.

Підсумовуючи, зазначимо: незважаючи на те, що інтерес до лексикографії в сербських наукових колах у кінці XX століття помітно зростає, у цей період у сербістиці практично відсутні праці, присвячені загальнотеоретичним питанням тлумачної лексикографрії. Цей фракт можна пояснити тим, що найбільш відомі сербські лексикографри багато уваги приділяють практичній роботі (перш за все створенню Словника САНУ). У результаті теорія сербської лексикографії значною мірою відстає в своєму розвитку від практики. Даринка Гортан-Премк так характеризує сучасну ситуацію в сербській науці: «Лексикографрічні рішення передують нашим теоретичним знанням, тому причину лексикографічних неузгодженостей слід шукати у повільності нашої теоретичної свідомості, а не в лексикографрічній неспроможності» [1]. Власне, ця тенденція сербської лексикографії цілком відповідає ретроспективному характеру лексикографрічної теорії у порівнянні з практикою в інших слов'янських мовах.

\section{Список використаних джерел:}

1. Гортан-Премк, Д. (1997). Полисемија и организација лексичког система у српскоме језику. Београд: Институт за српски језик САНУ.

2. Даничић, Ђ. (1976). Оглед. Рјечиик хрватскога или српскога језика. На свијет издаје Југославенска академија знаности и умјетности. (T. XXIII, с. 5-9); Загреб: JAZU.

3. Новаковић, С. (1888). Српска Краљевска Академија и неговање језика српског. Посланица академији наука философских од Стојана Новаковића. Прочитана на свечаном скупу академије, држаном 10 Септембра 1888. у славу стогодишњице Вука Стеф. Караџића Глас, $(\mathrm{X}), 21-87$.

4. Новаковић, С. (1893). Стојана Новаковића Предлог Српској Краљевској Академији учињен 5 априла 1893 да се отпочне купљење грађе за академијски Српски Речник, и да се за тај посао установи у Академији Лексикографски Одсек. Јавор, (7), 7.

5. Поповић, М. (1964). Вук Стеср. Карађии. Београд: Нолит.

6. Станковић, Б. (1999). Стилистичке инфрормације у речницима српског и руског језика. Београд: Славистичко душтво Србије. 
7. Стијовић, Р. (1995). Стојан Новаковић и модерна српска лексикографија. Стојан Новаковић - личност и дело, 367-371.

8. Tafra, В. (1988). Leksikografski izvori za rječnik JAZU i njegove dopune. Лексикограффuja u лексикологија, 107-113.

\section{СЕМАНТИЧНІ ВІДМІННОСТІ ТА СПОСОБИ ПЕРЕКЛАДУ АНГЛІЙСЬКИХ ПАРАМЕТРИЧНИХ ПРИКМЕТНИКІВ НUGЕ ТА GREAT (HА МАTЕРІАЛІ ФІЛЬMІВ КАНАЛУ ВВС THE BLUE PLANET TA LIFE)}

\section{Береговенко Наталія Сергіївна асистент кафедри романо-германської філології та перекладу Білоцерківський національний аграрний університет}

УКРАÏHA

Сучасний етап розвитку лінгвістики характеризується посиленою увагою до системного аналізу та структурування лексичного складу мови, зокрема назв розміру. Незважаючи на значні досягнення вітчизняної та зарубіжної лінгвістики у вивченні параметричних прикметників та неослабний інтерес вчених до них, не розв 'язаним й досі залишається ряд проблем. Так, проблема польової семантики прикметників 3 їх широким діапазоном лексичної сполучуваності належить до недостатньо вивчених, хоча вони досить багаті своєю семантикою і активно вступають в синонімічні та антонімічні зв'язки та відношення. Недостатньо вивченою залишається проблема їхнього перекладу. Під поняттям "параметричні прикметники" ми розуміємо прикметники, які означають великий чи малий розмір предметів та об`єктів навколишнього світу [2].

Параметричні прикметники входять до складу лексико-семантичної групи розміру. Згідно до класифікації Т. Линник, параметричні прикметники huge та great відносяться до мікрополя на позначення великого загального розміру. Прикметник great (8,9\%) вживався ще у давньоанглійській мові у значенні big, coarse, stout. У свою чергу він належить до західно-германського мовного ареалу grautaz. Сучасне значення "big in size, coarse" зв'явилося в середньоанглійський період. Great може реалізувати низку значень: 1) великий за кількістю чи ступенем; 2) відмінний, прекрасний; 3) великодушний, благородний, добрий; 4) надзвичайно талановитий [1]. Нас перш за все цікавить перше значення цього прикметника. У матеріалі прикметник great здебільшого вживається зі словами на означення віку - great age (1a). В обох варіантах перекладу, як в українському, так і в російському відбувається лексична заміна, оскільки подається еквівалент - неймовірного віку (1б) та невероятного возраста (1в). Наприклад:

(1a) These trees live life at such a slow pace, they can reach great age (Life, IX, 42:08).

(1б) Ці дерева ростуть дуже повільно і досягають неймовірного віку (Життя, IX, 42:08). 
(1в) Это дерево растет так медленно и достигает невероятного возраста (Жизнь, IX, 42:08).

Крім цього, great тяжіє до вживання із словами на означення протяжності (відстані) як-от: great distances (Life, V, 10:47), greater lengths (Life, IV, 07:52), які отримують адекватне відтворення при перекладі: величезні відстані (Життя, V, 10:47) та огромные расстояния (Жизнь, IV, 07:52) та слів на означення сили на зразок: great power (Life, V, 13:12), great strength (Life, VI, 31:40) - "дуже (надзвичайно) сильні" (Життя, V, 13:12), "огромную силу" (Жизнь, V, 13:12).

Параметричний прикметник great часто інтерпретується науковцями як слово переважно з абстрактною семантикою, на відміну від large та big, які часто вживаються при позначенні розміру конкретних фрізичних об`єкті, як-от: greater challenge (Life, II, 33:16), great influence (BP, I, 23:44), great innovation (Life, VI, 33:15), greatest talent (Life, VII, 22:19), greater extremes (Life, V, 21:35), great speed (BP, III, 34:48), greater dangers (BP, V, 10:20).

Хоча, дослідники зазначають, що при позначенні великого загального розміру конкретних предметів great, наприклад, вживається частіше ніж його синоніми із значенням "величезний" - huge, enormous та інші [3]. Також досліджуваний прикметник має відмінність семантичного та функціонального характеру, вживаючись здебільшого тоді, коли підкреслюється надзвичайно великий розмір предмета. Це викликає різного роду емоції - страх, захоплення, здивування і т. д. Подібно до прикметника large, досліджувана одиниця часто вживається зі збірними іменниками, як-от: swarm (BP, VII, 44:54), gathering (Life, II, 27:26), schools (BP, I, 46:04), column (Life, IV, 44:28), numbers (BP, III, 30:18), quantity (Life, VIII, 10:26), shoals (Life, IV, 43:13), colony (Life, V, 29:34).

Висновки. Отже, прикметники great та huge при перекладі відтворюється адекватно, але із застосуванням низки лексико-граматичних трансформацій, а саме: лексичної заміни, додавання слова, заміни слова однієї частини мови на слово іншої (номіналізації, вербалізації, адвербалізації). Great вживається частіше 3 абстрактними та збірними іменниками, a huge - 3 іменниками збірності. Також great вживається здебільшого тоді, коли підкреслюється надзвичайно великий розмір предмета, який викликає у мовця різноманітні емоції - страх, здивування, радість і т. д. Huge, як правило, використовується задля позначення об`ємних предметів, а також поєднується із іменниками, які означають конкретні об`єкти як об`ємної, так і пласкої характеристики, збірні та абстрактні поняття.

\section{Список використаних джерел:}

1. Андрусь, А. Ф. (2009). Концептуальний простір англійських прикметників big ma large (автореф. дис. ... канд. філол. наук). Чернівецький національний університет ім. Юрія Федьковича. Чернівці, Україна.

2. Береговенко, Н. С. (2018). Особливості вживання на способи перекладу англійських параметричних прикметників small тa little (на матеріалі фільмів каналу BBC "The Blue Planet" та "Life"). Наукові записки. Серія: Філологія (мовознавство), (26), 127-132.

3. Дзеньдзюра, Н. І. (2010) Словотвірні гнізда параметричних прикметників (автореф. дис. ... канд. філол. наук). Національний університет «Львівська політехніка». Львів, Україна. 
4. A BBC/Discovery Channel: Blue Planet (series 1-8). (2001). Alastair Fothergill, Andy Byatt \& Martha Holmes (producers); Martin Elsbury (editor); Rick Rosenthal (cameraman); David Attenborough (narrator); George Fenton (music composer); BBC concert orchestra (music performer); Magdalen College Choir (titles' music singer).

5. ВВС: Блакитна планета (серії 1-8). (2001). Алістер Фотергіл, Енді Біатт \& Марта Холмс (продюсери); Мартін Елсбері (редактор); Рік Розенталь (оператор); Девід Аттенборо (ведучий); Джордж Фентон (музичний композитор); концертний оркестр ВВС (музичний виконавець); хор коледжу Магдалини (виконавець головного саундтреку).

6. ВВС: Голубая планета (серии 1-8). (2001). Алистер Фотергилл, Энди Биатт \& Марта Холмс (продюсеры); Мартин Элсбери (редактор); Рик Розенталь (оператор); Дэвид Аттенборо (ведущий); Джордж Фентон (музыкальный композитор); концертный оркестр ВВС (музыкальный исполнитель); хор колледжа Магдалины (исполнитель главного саундтрека).

7. A BBC/Discovery Channel: Life (series 1-10). (2009). Martha Holmes (co-production series producer); Michel Hanton, Rupert Barrington, Adam Chapman, Martha Holmes, Neil Lucas, Patrick Morris \& Ted Oakes (producers); David Attenborough (narrator); George Fenton (music composer).

8. ВВС: Життя (серії 1-10). (2009). Марта Холмс (продюсер серій); Майкл Гантон, Руперт Баррінгтон, Адам Чепмен, Марта Холмс, Нейл Лукас, Патрік Морріс \& Тед Оейкс (продюсери); Девід Аттенборо (ведучий); Джордж Фентон (музичний композитор).

9. ВВС: Загадки природы: Жизнь (серии 1-10). (2009). Марта Холмс (продюсер серий); Майкл Гантон, Руперт Баррингтон, Адам Чэпмен, Марта Холмс, Нейл Лукас, Патрик Моррис \& Тед Оейкс (продюсеры); Дэвид Аттенборо (ведущий); Джордж Фентон (музыкальный композитор).

\section{ХУДОЖНЄ ОПРИЯВЛЕННЯ СОЦІАЛЬНИХ ВИКЛИКІВ У ТВОРАХ БАРБАРИ КОСМОВСЬКОЇ}

Мартинець Алла Михайлівна

ДВНЗ «Прикарпатський національний університет імені Василя Стефраника»

УКРӒ̈HA

Впродовж століть кожна національна література відгукується на зміни, які переживає суспільство, а у твори входять реалії життя з його позетивом $\mathrm{i}$ проблемами. Завдячуючи створеним митцями слова художнім образам, сюжетним лініям читач може гіпотетично припустити, окрім декларованого, своє рішення представленої у творі конфріктної ситуації, поміркувати над вибором героїв та запропонувати свій варіант вирішення проблеми, що допомагає як з власним вибором, так і з розумінням сучасних викликів і загроз.

У творах художньої літератури в цілому, та польської зокрема, порушення ряду соціально-психологічних проблем спрямоване на пошук шляхів, які б могли допомогти знайти вихід з тієї чи іншої складної ситуації. У сучасних творах з'являються персонажі, які водночас $€$ сучасними героями, котрі люблять пізнавати світ за допомогою здобутих знань з одного боку, а з іншого стикаються з надприродніми сутностями та реальними проблемами. Такі герої 
виявляються близькими та зрозумілими читачам своїми переживаннями, страхами, проблемами. Вони допомагають їм краще зрозуміти себе і світ, у якому живуть.

Проза Б. Космовської порушує цілу низку проблем у житті, що виникають під впливом життєвих обставин. Серед них: криза в родині, дружба і перше кохання, комплекси, розчарування, інвалідність, пошуки себе, проблеми ігрової залежності, урбанізації та пов'язані з нею проблеми руйнації сільських общин, соціальна нерівність та стосунки батьків і дітей, проблеми інвалідності, самотності та соціального відчуження і, насамкінець, проблеми смерті. Такі проблеми, впливаючи на людство, були перенесені у площину літератури і почали існувати у двох площинах: як пересторога та як констатація. Про це йдеться у творах «Буба», «Буба. Мертвий сезон», «Золота рибка», «Українка».

Проза Б. Космовської представляє читачеві як індивідуальні, так і суспільні слабкості, та у її творах відсутня відповідь на запитання: що робити після констатації факту.

Так героїня твору Б.Космовської «Буба» - 16 літня дівчинка Агнешка, яку у сімї називають Бубою. Вона кмітлива, старанна, захоплюється класичною музикою. Та життя її далеке від щасливого. Поруч із живими батьками, вона глибоко самотня: «Дівчина не раз замислювалася, чи хтось у сімї знає, як їі звуть насправді. Про всяк випадок нікому не задавала цього незручного питання. Зрештою, байдуже, яке ї справжнє ім'я, якщо його взагалі не використовують» $[4,5]$.

Друзі вважали її зрадницею, краща подруга зустрічалася з хлопцем ії мрії, батькам на неї начхати: мати цікавиться тільки власною зовнішністю, а для батька сенсом життя є слава. Єдиною близькою людиною для героїні $€$ дідусь.

Зображаючи сучасників, Б. Космовська створює панораму психологічних характерів, гаму почуттів та емоцій. У домі Буби є все, що потрібно для щастя сучасного підлітка. Маючи майже нормальну сім'ю Агнешка не розуміє, що має зробити, щоб її сприймали такою, якою вона $є$ насправді. А вона така звичайна у прагненні батьківської уваги. Буба особлива у своїй дотепності та виваженості, у чому перевершує навіть дорослих. Як жити підлітку з таким наборм проблем? Шукати можливість втекти від них. Такою втечею для героїні стає втеча угру в брідж.

Одним із соціальних викликів сьогодення $є$ класична проблема батьків і дітей, що оприявлюється у модифікованій формі конфлікту поколінь. Цю проблему порушувало вже не одне покоління письменників, але з кожним десятиліттям вона постає з новою силою, тому до сих пір немає успішного рецепту її вирішення, як у літературі, так і в буденній реальності. Найчастіше причиною цієї проблеми стає непорозуміння. Дітям здається, що батьки піклуються про них надмірно і дратуються через те, що рідні люди обмежують їхній особистий простір. Батьки у свою чергу жаліються на дітей через їхню егоїстичність та надмірне прагнення швидкого дорослішання. Інколи батьки настільки сильно зайняті собою та своєю роботою, що зовсім не помічають дітей, і свою присутність намагаються компенсувати розкішними подарунками та пристойними кишеньковими. Результатом такої штучної опіки стає те, що молоді люди, спраглі батьківської та материнської уваги, або відгороджуються від суспільства та замикаються у собі, або ж стають на шлях злочинництва. 
Інколи діти виховуються у неповних сім'ях. Така ситуація формує відчуття покинутості з одного боку, або ж з іншого - впевненість і впертість, готуючи до боротьби за виживання у жорстокому світі. Проблема поколінь $\epsilon$ сюжетотворчою у багатьох творах польської письменниці.

Світ, створений Б.Космовською складний і заплутаний. У ньому усе змішалося, тому розділити людей на позитивних і негативних практично неможливо. Тільки любов може відновити втрачений баланс. "...Буба почала сумувати за нормальними сімейними ситуаціями. ... Зовсім нещодавно Бубині мрії зосереджувалися на тому, аби всі вони бодай один день провели поза домом. Зараз вона все б віддала, щоб повернути ці нестерпні, дратівливі, але такі необхідні для родинного життя хвилини в помешканні на Звіринецькій» [4, с. 80].

Основою, яка рухає сюжет іншої історії, написаої польською авторкою теж є любов. Бо тільки вона змінює світ Аліції, героїні твору «Золота рибка». У неї, як і у Агнешки маса проблем: батьки рзлучені. Мама з головою занурена у роботу, а тато одружився вдруге. Як результат - у Агеншки появляється брат Фридерик. Дівчинка відчуває до нього особливе тепло і усвідомлюючи, що братик захворів на невиліковувану хворобу, вона намагається відчайдушно для нього щось зробити. Вона купує для нього позолочену рибку, чекаючи на диво казки. Та казка у реальному житті неможлива: дитина помирає.

Поруч із заявленими у інших творах проблемами, тут Б. Космовська піднімає проблему нематеріальних цінностей. Найдорожчим попри усе $є$ життя. Письменниця наголошує, що суспільство, де ці ціності втрачені, зникне, адже приятеля Аліції Роберта рятує, даруючи скрипку, німецький роботодавець. У нього більше людяності, аніж у співвітчизників.

Піднімає у своїх творах польська авторка іще одну, надзвичайно складну проблему - проблему поневірянь у пошуку кращого життя чужими країнами, проблему заробітчанства, втрати себе та пошуку щастя, дотично утверджуючи на цьому тлі уже описані раніше проблеми.

Однією із героїнь твору Б.Космовської стає дівчина з України Іванка, яку згодом на чужині назвуть не інакше як «володарка іржавого умивальника, королеву затхлого лінолеуму й пощербленого начиння» [5]. Авторка створює образ, надзвичайно важливий не тільки для України, але і для Польщі, образ, який константує наявність проблеми, та не дає відповіді щодо її вирішення. Письменницю цікавить: чи можуть стати щасливими ті, хто покинув свій дім і відправився шукати щастя у невідомі світи. Текстом доводиться, що щастя на чужині - це примара. Саме тому інтелігентка Іванка Матвієнко 3 консерваторською освітою перетворюється не просто на заробітчанку, вона стає просто "українкою»: людиною без імені, без минулого, а часто і без надії. Вона «хатня робітниця», «наймана прибиральниця», "доглядальниця», «дім-сад-город-піклувальниця з України». Та доля українки у Польщі, то не поодинокий приклад маловідомої авторці країни. На жаль польські дівчата, вибравши такий же шлях трудових емігрантів покидають свою вітчизну та їдуть далі, до Європи, і там перетворюються на таких же безімених і безликих.

О. Галета, аналізуючи рман «Українка» зазначає: «Історія Іванки драматична по-іншому, аніж історії польських персонажів: це не тільки 
особиста пригода, це також історія трудової міґрантки, приреченої перебувати у самому низу суспільної ієрархії, незалежно від власних талантів і здібностей. На її плечі перекладають тягар історичних образ і стереотипів: за Волинь і безробіття, за ґендерну нерівність і подружню зраду, навіть за радянську загрозу й пострадянську Москву. Адже вона десь звідти, з незрозумілого сходу, а отже, відповідальна за все, що приходить з темної сторони світу, включно 3 дитячими страхами і дорослими фообіями» [1].

Відповідальність за усе, до чого не причетний, $є$ ще одним викликом соціального характеру, представленим Б. Космовською у творі. I хоча авторка не прописує рецептів щод вирішення піднятих проблем, ії заслугою є уже той фракт, що вона ці проблеми озвучує.

\section{Список використаних джерел:}

1. Галета, О. Вихід у світ, або Казка про українську Попелюшку. Вилучено 3 https://zbruc.eu/node/9601.

2. Дуняшенко, Н. (2016). Хто допоможе Дівчинці-підлітку пережити непрості життєві моменти? (за романом Барбари Космовської «Буба»). Зарубіжна література в школах України, (3), 12-16.

3. Книга Барбари Космовської про українську заробітчанку-прибиральницю вийде в Україні. Вилучено 3 https://vsiknygy.net.ua/news/28049/.

4. Антоняк, Б. (пер з пол.). (2012). Космовська Барбара. Буба. Львів: Урбіно.

5. Теслюк, О. (пер. з пол.). (2017). Космовська Барбара. Українка. Тернопіль: Навчальна книгаБогдан. 


\title{
SECTION 12. \\ POLITICS
}

\section{ПРИЧИНИ ТА ШЛЯХИ ПОДОЛАННЯ АБСЕНТЁ̈ЗМУ ЄВРОПЕЙСЬКОї МОЛОДІ}

\author{
Махно Катерина Олексіївна \\ здобувач вищої освіти юридичного факультету \\ Дніпровський національний університет імені Олеся Гончара
}

Науковий керівник: Ведькал Валентина Андріївна канд. іст. наук, доцент, доцент кафедри європейського та міжнародного права Дніпровський національний університет імені Олеся Гончара

УКРАЇНА

Вибори у Європейському Союзі є, мабуть, одним з найбільших парадоксів євроінтеграції. У відповідь на критику дефріциту демократії у країнах союзу, Європарламенту було надано широке коло повноважень, як інституту, який безпосередньо представляє громадян на рівні ЄС. Майже безправна асамблея, яка не обиралася громадянами у 1950-х роках, перетворилася на співзаконодавця. Протягом усієї історії інтеграції, повноваження постійно перерозподілялися між інституціями та країнами-членами ЄС. Парламент, однак, був однією інституцією, яка поступово, з кожним реформуванням договорів, лише збільшувала свої повноваження.

Однак, починаючи з 1979 року явка виборців постійно знижувалася. Європейські вибори 2009 року відзначилися 65\% показником неявки молоді, який зовсім невластивий для демократичної політики. Частка молодого населення, яке взяло участь у виборах, була майже на $30 \%$ нижчою, ніж частка виборців старшого віку.

Падіння явки молодих виборців з кожними наступними виборами $\epsilon$ загальною тенденцією у всіх європейських країнах. Це явище пов'язане, серед іншого, з абсентеїзмом, причому, не тільки політичним, але й соціальним, економічним тощо.

Причини абсентеїзму та змінні, що впливають на нього неодноразово досліджувалися. Фактори, які можуть призвести до абсентеїзму бувають двох видів: соціологічними та обставинними [1]. Соціологічні чинники, найчастіше, пов'язані з соціальним домінуванням однієї соціальної групи над іншою, або вони $€$ наслідком поганої соціальної інтеграції особи, а обставинні - 3 конкретними виборами, з конкретним політичним контекстом та їх впливом на поведінку виборців.

Для багатьох абсентеїстів байкотування виборів - це не просто протест, а радикальна критика всіх форм влади та можливий шлях побудови іншого майбутнього.

На думку вчених, політичний абсентеїзм європейської молоді на виборах пов'язаний з двома суттєвими політичними змінами, які відбулися за останні два десятиліття. Першою є питання легітимності процесу європейської 
інтеграції. ЄС розширив свою компетенцію та вплив набагато швидше, ніж громадськість була до цього готова. Тому, абсентеїзм молодого населення яскраво демонструє, що життя у все більш інтегрованій Європі не є тим стимулом, який міг би їх переконати брати участь у виборах.

По-друге, зменшення явки виборців загалом і серед молодого населення зокрема, безпосередньо пов'язане зі змінами форм політичної соціалізації та активізму. Політичну соціалізацію досі проводять як формальні, так і неформальні національні політичні інститути, а це означає, що підґрунтя політичного абсентеїзму корениться також і у неправильній національній політиці.

Політичні партії залишаються головним видом політичної участі громадян в житті Європі вже більше століття. Однак, сьогодні, між політичними партіями та молоддю зростає розрив, про що свідчить сильний спад ії членства протягом останніх двох десятиліть: у Європі лише 2\% молоді є членами політичних партій. Членство в партії зараз стало настільки рідкісним явищем, що його вже важко розглядати як показник прихильності до тієї, чи іншої політичної сили.

Дослідження вказують на те, що зростаюча недовіра молодого покоління до партій пов'язана з тим, що останні зовсім не намагаються знайти спільну мову з ними. Держави-учасниці, в особі політичних партій, відриваються від свого природного коріння в суспільстві і перетворюються на частину державного апарату: політичні партії загальноєвропейського рівня не виконують тих функцій, які виконують національні.

Молодь не $€$ аполітичною, але, як правило, віддає перевагу чітко визначеним та зрозумілим проектам, а тому, для партій, які хочуть бути обрані до Європарламенту, які хочуть отримати голоси молодого електорату надзвичайно важливо визначити конкретні, нагальні проблеми та питання, які стануть частиною виборчої кампанії [2].

До того ж, необхідно обов'язково залучати молодих людей шляхом їх призначення на відповідальні посади в партії, або безпосередньо висувати їх як кандидатів, оскільки й досі залишається розрив між часткою молодих кандидатів на виборні посади та часткою молоді в ЄС: за даними Євростату, $26 \%$ населення ЄС - віком від 18 до 35 років, але лише 19\% кандидатів були в цьому віковому діапазоні.

\section{Список використаних джерел:}

1. Кулеба, О. \& Бучин, М. (2011). Абсентеїзм як форма низької політичної участі. Українська національна ідея: реалії та перспективи розвитку, (23), 98-102. Вилучено 3 http://ena.lp.edu.ua:8080/bitstream/ntb/10381/1/17.pdf.

2. Іванов, М. С. (2002). Політичні орієнтації молоді України: стан і тенденції. Наукові записки, (20), 235-238. Вилучено 3 http://ekmair.ukma.edu.ua/bitstream/handle/123456789/9140/lvanov_Politychni_oriyentaciyi_mo lodi.pdf?sequence=1\&isAllowed=y. 


\title{
ПРО ВПЛИВ ГЛОБАЛІЗАЦІЇ НА ЗМІНУ ЗМІСТУ ФУНКЦІЙ СУЧАСНИХ ДЕРЖАВ
}

\begin{abstract}
Музиченко Ганна В'ячеславівна
д-р. політ. наук, професор, професор кафедри політичних наук і права Південноукраїнського національного педагогічного університету імені К. Д. Уиинського УКРАÏHA
\end{abstract}

У сучасній науковій літературі дискусія відбувається навколо тези про послаблення економічних функцій держави та їх витіснення у сореру суто гуманітарних відносин, що відбувається внаслідок глобалізаційних змін та трансформації ролі держави в економіці та в суспільному розвиткові зокрема.

Сучасність за висловом А. Гальчинського характеризується тим, що: «...відбувається суперечливий процес самозаперечення держави, однак держава не зникає взагалі - зникає традиційна (класична) держава індустріального суспільства, звична для нас держава модерністської культури. Водночас у великих муках, ще, природно, повною мірою не визначивши свої базові засади, народжується держава нового типу - держава постіндустріалізму» [1].

Згідно з позицією західних дослідників, головна проблема зараз полягає в тому, що державі все складніше становиться здійснювати фінансування «великої соціальної політики», оскільки необхідні запозичення в нових умовах стають більш витратними у порівнянні з попереднім періодом, коли уряди мали більші можливості залучення додаткових ресурсів. 3 певного моменту вказані зміни стали формувати межі стратегії, спрямованої на зміну ролі та функцій держави в економіці та соціальному розвитку. «Така політика спрямована на трансформацію моделі, виходячи 3 нового контексту взаємодії між різними галузевими та корпоративними інтересами, соціальними партнерами та соціальними групами. Одним з провідних аспектів $€$ зміна балансу між факторами виробництва (капіталом та працею), що на рівні суспільства знаходить відображення в посиленні позицій підприємців, а основні зусилля держави спрямовуються на підвищення ефективності конкурентної політики» [2].

Держава втрачає суто класовий характер і дедалі більше стає виразницею загальнонаціональних інтересів. У діяльності держави пріоритетного значення набувають соціальні функції: інвестиції в соціальну інфраструктуру, політика ефективної зайнятості, гармонізація відносин між працею і капіталом, підтримка недостатньо захищених верств населення, забезпечення рівних можливостей у виборі умов своєї праці, життя тощо. На основі реалізації цих функцій розвивається держава state welfare - соціально відповідальна держава, або держава загального добробуту, що перетворює соціальну політику держави на головний напрям державної політики сучасних країн світу.

Посилення соціальних функцій держави, які значною мірою реалізуються на неекономічній основі, також супроводжується звуженням сфери їі 
економічної політики, безпосереднього впливу на суто виробничі процеси, однак держава не стає від цього слабшою. Потрібно і тут ураховувати природність відповідних трансформацій. «Якісний перехід до соціально відповідальної держави уможливлюється на основі змін, що відбуваються у класових відносинах. Ідеться про дифузію соціально-економічних і політичних детермінант класової структури суспільства, посилення соціальної мобільності індивідів» [3]. На відміну від класових структур, які відображають усуспільнення основних систем життєдіяльності великих мас населення, в сучасному розвитку дедалі більшого значення набувають соціальні структури, що дають змогу людині повніше реалізувати принципи індивідуальної свободи, особисті здібності [4].

Інтеграційні процеси посилюють й вагомість міжнародного співробітництва та додають нову функцію в портфель національних держав - необхідність поєднувати вимоги зовнішньої та внутрішньої політики. Міжнародне співробітництво здебільшого покладається на державно-приватне співробітництво та на конкуренцію. Хвиля зміни балансу між ринком та державою, що охопила світ в останні десятиліття, змінила методи управління державою на національному рівні, віддаючи перевагу міжурядовим організаціям.

Отже, нова архітектура світоустрою, що розбудовується на наших очах, свідчить про зміну ролі та функцій держави, формуванню нової концепції міжнародних відносин поствесторальського устрою, що характеризується трансформацією націй-держав. Як наслідок, соціум вимагає від держави взяти контроль за ситуацією в свої руки, поступаючись інколи й елементами свободи. Тому національна держава залишається найважливішою силою у формуванні світового суспільно-політичного процесу та в світовій економіці зокрема.

\section{Список використаних джерел:}

1. Гальчинський, А. (2016). Глобальні трансфоормації: концептуальні альтернативи: методологічні аспекти. Київ: Либідь.

2. Muzychenko, G., Koliada, T., Churkina, I. (2017). Impact of European Integration Process on the Necessity of Long-Term Budget Planning Introduction in Ukraine. Baltic Journal of Economic Studies, 3(5), 329-333.

3. Muzychenko, G., Koliada, T. (2018). Evaluation of State Intervention to the Country Economy by Global Democratic Markers. Scientific Development and Achievements. London, UK.

4. Музиченко, Г.В.(2011). Державна політика як уособлення функцій держави в сучасних країнах пострадянського простору (2011). Політологічний вісник. зб-к наук. праць (Вип. 55, с. 391-399). Київ, Україна: «ІНТАС». 


\section{SECTION 13.}

LAW

\section{MÌNEACHAIDHEAN TEICNEÒLAS LAGHAIL CO-CHUNNTAS ANN AN ALBA}

\section{Aleksey Maksurov \\ PhD ann an Lagh, Ollamh Co-cheangailte, Roinn Teòiridh agus Eachdraidh Stàite is Lagh ${ }^{1}$, Òraidiche (Dàmh an Lagha) ${ }^{2}$ ${ }^{1}$ Stèidheachd Foghlaim Buidseit Stàite Feadarail "Oilthigh Stàite Yaroslavl air ainmeachadh às deidh Thuirt P.G. Demidova" \\ CAIDREACHAS NA RUIS \\ ${ }^{2}$ Oilthigh Sorbonne ann am Paris \\ POBLACHD NA FRAINGE}

Ann fhèin, tha co-òrdanachadh aig cridhe an lagh, leis gur e am prìomh adhbhar aige dàimhean sòisealta a riaghladh. Is e feartan na dreuchd seo, am measg rudan eile, co-òrdanachadh dhàimhean sòisealta.

A thaobh lagh, faodar barrachd a ràdh: chan eil ach lagh, mar sheata de gnàthasan ceangailteach san fharsaingeachd, na shiostam aonaichte ann an comann eagraichte stàite a bhios a 'feuchainn ri gnìmhan dhaoine a choòrdanachadh agus a sgioblachadh.

Mar sin, tha co-òrdanachadh na sheilbh maireannach den lagh, aig an aon àm a phrionnsapal agus a dhleastanas, a dhòigh-obrach agus an toradh a tha thu ag iarraidh. Chan eil seo a 'ciallachadh, gu dearbh, gu bheil an lagh gu lèir air a lughdachadh dìreach gu co-òrdanachadh, tha direach co-òrdanachadh san lagh air a nochdadh ann an obrachadh ionadan laghail agus uinneanan gu tur eadardhealaichte. Seo mar a tha coileanaidhean teicneòlas laghail co-òrdanachaidh air an nochdadh ann an dùthchannan Eòrpach.

Gu mì-fhortanach, cha do lorg sinn gnàthasan co-òrdanachaidh ann an achdan bun-reachdail na h-Alba. Chan eil ach ullachaidhean ann an cruth dearbhaidhean fuzzy gun a bhith a 'nochdadh an dòigh-obrach airson an tagradh.

Chan eil e na iongnadh nach eil an teagasg saidheansail mu cho-òrdanachadh ann an Alba air a leasachadh idir: às aonais stuthan cudromach "bun-sgoile" airson rannsachadh saidheansail - gnìmhan riaghlaidh aig ìre bun-reachdail - chan eil e furasta a dhol an sàs ann an rannsachadh làn-chuimsichte.

Ach, is fhiach aithneachadh nach eil lagh na h-Alba mar as trice ach ag ràdh gu bheil feum air co-òrdanachadh. Chan eil inbhean co-òrdanachaidh sònraichte, mar riaghailt, rim faighinn ach ann am fo-laghan Riaghaltas na h-Alba.

Tha seo, gu dearbh, na fhìor tharraing de riaghladh co-òrdanachaidh.

Fìr, tha eisgeachdan tlachdmhor don riaghailt seo.

Mar eisimpleir, tha Achd Cumhachd Coimhearsnachd (Alba) 2015 a 'toirt seachad uidheamachd airson ùghdarrasan poblach agus feadhainn coitcheann 
ionadail a cho-òrdanachadh stèidhichte air feumalachdan an t-sluaigh ionadail, a tha air a chuir an cèill ann an iomlaid bheachdan, co-dhealbhadh a' toirt aire do fheumalachdan ionadail, msaa. [1].

Tha an cleachdadh ann a bhith a 'cruthachadh buidhnean co-òrdanachaidh airson pròiseactan laghail stàite fa leth farsaing:" Tha comhairle MSS fhèin air a dhèanamh suas de bhuill agus riochdairean chomataidhean, buidhnean obrach agus buidheann litrichean eadar-roinneil a bhios a 'dèiligeadh ri cùisean coòrdanachaidh" [2].

Is e aon bhuannachd chudromach eile gu bheil glè bheag de raointean de bheatha phoblach air an còmhdach le riaghladh co-òrdanachaidh. Gu bunaiteach, tha sinn a 'bruidhinn mu dheidhinn co-òrdanachadh ann an raon gnìmhachd ùghdarrasan ionadail, foghlam agus cùram slàinte, dìn stòrasan nàdurrach, poileis agus raointean eile.

\title{
Liosta de na stòran a chaidh a chleachdadh:
}

1. Achd Comasachaidh 2015 (Alba). (2015). Retrieved from http://www.gov.scot/Topics/Government/PublicServiceReform/CP.

2. Conaltradh Oifigeil Riaghaltas na $h$-Alba. Retrieved from http://www.gov.scot/Topics/marine/Publications/supporting/MSSAnnRev/MSSReview 201516/Environment.

DOI 10.36074/25.10.2019.v3.04

\section{PROTECTION OF PROPERTY RIGHTS IN THE AREAS OF CONDUCTING UNITED FORCES OPERATION}

\begin{abstract}
D.Sc. (Law), Professor, Head of the Department of Civil Law and Procedure Educational-Scientific Institute of Law, Psychology and Innovative Education National University "Lviv Polytechnic»
\end{abstract}

Iryna Lychenko

UKRAINE

Loss of movable and immovable property in the areas of conducting united forces operation as a result of the hostilities, lack of the protection of property, which is located in the occupied part of Ukraine and at the "dividing line", where the implementation of transactions concerning the property is difficult, lack of a proper system of carrying out compensatory payments for destroyed, damaged housing, property expropriated in connection with the implementation of mobilization measures, mechanisms of compensation for lost dwelling, the cost of construction and acquisition of housing instead of destroyed ones are the significant factors reflecting the methodological problems of the protection of property rights in Ukraine. According to the rating of International Property Rights Index, Ukraine has taken the $123^{\text {rd }}$ position among 127 countries [1].

The OSCE Special Monitoring Mission to Ukraine has repeatedly stressed on this problem. It was reported that the property of the civilian population from both sides of the line of collision was damaged as a result of the numerous cases of 
mortar and artillery shelling. According to the thematic report of the OSCE Special Monitoring Mission to Ukraine "Difficult situation of the civilian population affected by the conflict in the East of Ukraine" 2017, the total amount of losses for the destroyed or damaged property is 1884.4 million UAN, the total number of damaged or destroyed facilities - 9029, including: 838 houses of communal property, 24 building and loan associations, 42 - condominiums and 8125 - private dwelling houses. In Luhansk oblast the total amount of losses for the destroyed or damaged property is 519.8 million UAN, the total number of damaged or destroyed facilities 6857, including: the damaged objects - 6310 (994 apartments and 5316 houses); the destroyed objects - 547 (129 apartments and 418 houses) [2].

In accordance with the Comprehensive National Programme for Support, Social Adaptation and Reintegration of Citizens of Ukraine Internally Displaced from the Temporarily Occupied Territory of Ukraine and ATO Conduct Area to Other Regions of Ukraine for the period until 2017, approved by the resolution of the Cabinet of Ministers of Ukraine No. 1094 dated December 16, 2015, the task for the period of 2016-2017 was ensuring the right of internally displaced persons to housing. However, at present, the procedure for the implementation of this right is not defined in the legislation. Among the problems of the citizens of Ukraine internally displaced from the temporarily occupied territory of Ukraine and ATO conduct area to other regions of Ukraine, this program determined the lack of information about the amount of damages (property damage) caused to displaced persons in course of hostilities and the mechanism of their compensation. The program declared a commitment to eliminate this problem until 2017. Despite the declared commitment, today there is no normative and legal act, which would have determined the mechanism of compensatory payments for destroyed, damaged housing, property expropriated in connection with the implementation of mobilization measures or there is no body, which would have carried out an assessment of the damage. The Verkhovna Rada of Ukraine registered the bill. However, on December 22, 2016, the Verkhovna Rada did not pass it. The alternative bill has not been proposed for consideration.

A great number of citizens consider inefficiency of the activities of public administration concerning the protection of property rights in Donetsk and Luhansk oblasts as an important economic and legal factor that affects the property in terms of UFO and ATO. The biggest problem is the lack of a special body of the protection of property rights of citizens affected as a result of conducting UFO and ATO. The creation of such a body of state power would allow beginning a detailed assessment of the damage caused to the property of citizens, the development of the concept of a phased return of citizens left for other countries because of conducting united forces operation to the previous place of residence. Achievement of this aim should be accomplished through the development of the system of compensatory payments for violations of property rights, the establishment of the comprehensive procedure for obtaining affordable housing. The experience of forming safeguards for the protection of property rights of persons affected by the Nagorno-Karabakh armed conflict should become the example for Ukraine. As a result of the implementation of the State programme on refugees and forced migrants in Nagorno-Karabakh, over 180000 internally displaced persons and refugees moved into more than 80 specially constructed settlements [3].

Today, many European countries, the United States and international organizations provide assistance to persons who suffered from conducting united 
forces operation, and among them: Red Cross Society, Person in Distress, UNICEF, Office of the United Nations High Commissioner for Refugees (UNHCR), Caritas and others. Measures implemented by these international organizations are deprived of coordination with each other and they only partially ensure the protection of property rights. Property rights of people are still not protected due to the lack of a clear mechanism for implementation of the compensatory payments for citizens who lost their housing, a unitary administrative center for coordination of such measures.

Conclusions. In order to reduce migration of the population of Donetsk and Luhansk oblasts, Ukraine should create reliable economic and legal principles of protection of property rights that include the opportunity to possess, use and dispose of property in this region, which is guaranteed by the state due to normative and legal acts, the functioning of public institutions, which can protect this right, the mechanism of compensation for lost, damaged movable and immovable property. Creating effective economic and legal principles of protection of property rights in the areas of conducting united forces operation in Ukraine is connected with a number of important reforms. A special state program of economic integration of the territories affected by conducting united forces operation should become the economic and legal basis for strengthening the protection of property rights in the areas of conducting united forces operation. It is important to adopt a new program of economic development of Donetsk region, the state program of strengthening the protection of property rights of citizens of Ukraine in Donetsk and Luhansk oblasts. On the model of other countries that have experienced armed conflicts, Ukraine should provide funding for the construction of special settlements in order to return internally displaced persons to abandoned places of habitual residence. It is necessary to establish a mechanism of compensation for damaged or destroyed real estate, plots of land and personal property. It is necessary to create a government body protecting the property rights of persons affected by hostilities, which would include a special commission for assessment of damages incurred as a result of hostilities, determination of the amount of the required compensation, a complex of measures aimed at restoration of the technical conditions of the building structures of ownership, engineering networks and systems.

\section{References:}

1. International property rights index. Property Rights Alliance. (2017). Retrieved from

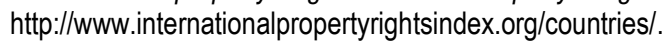

2. Спеціальна моніторингова місія ОБСє в Україні. (2017). Складне становище цивільного населення, яке постраждало від конфрлікту на сході України: тематичний звіт. Вилучено 3

http://www.nbuviap.gov.ua/index.php?option=com_content\&view=article\&id=2177:vidshkoduvan nya-zbitkiv-zavdanikh-zhitlu-naselennya-v-zoni-ato\&catid $=8 \&$ Itemid $=350$.

3. Технічна робоча група з питань житла, землі та майна. (2017). Закордонний досвід забезпечення житлом внутрішньо переміщених осіб та компенсації за пошкоджене/зруйноване житло виконано. Shelter Cluster Ukraine. Вилучен 3 https://www.sheltercluster.org/sites/default/files/docs/foreignexperiencehousingforidpsintegrated-ukr_0.pdf. 


\title{
АКТУАЛЬНІ ПИТАННЯ ІНСТИТУТУ ЕЛЕКТРОННИХ ДОКАЗІВ В ЦИВІЛЬНОМУ ПРОЦЕСІ
}

\begin{abstract}
Шостак Юлія Олександрівна
студентка 4-го курсу

Дніпровський національний університет імені Олеся Гончара
\end{abstract}

Науковий керівник: Резнікова М.О канд. юрид. наук, доцент кафедри цивільного, трудового та господарського права Дніпровський національний університет імені Олеся Гончара

УKPAÏHA

Вдосконалення інформаційних технологій, використання нових можливостей обміну інформацією знайшли свій прояв і в сфрері цивільного судочинства. 3 використанням різних фоорм електронних комунікацій, з'явився новий термін - «електронні докази», щодо якого активно дискутують вченіправники. Серед тих, які нещодавно досліджували подібні теми можна назвати: Гусєва О.Ю., Лазько О.М, Павлова Ю.С., Петренко В.С, Фурса С.Я.

Впровадження якихось змін в певні сфери суспільного життя не завжди поряд йде з нормативним регулюванням цих змін. Спроба законодавчого врегулювання електронних засобів доказування була здійснена з набранням чинності 15 грудня 2017 року нових редакцій процесуальних кодексів. Зокрема, електронні докази були визнані самостійним засобом доказування як у цивільному, так і в господарському та в адміністративному процесах. Незважаючи на це, судова практика на сьогодні не $є$ однозначною в питаннях застосування електронних доказів, тому варто погодись як з багатьма вченими у галузі права, так і з юристами-практиками, що на сьогоднішній день відсутнє належне нормативно-правове регулювання статусу електронних доказів в цивільному процесі.

Слід зазначити, що в юридичні літературі є прихильники такої точки зору, що електронні докази взагалі не потрібно виокремлювати в іншу категорію доказів, оскільки всі сучасні джерела інформації охоплюються вже відомими процесуальному законодавству засобами доказування і їх необхідно відносити або до речових, або до письмових доказів. Зокрема у свої роботі Петренко В.C відстоює цю позицію та наводить приклад інших країн, законодавство яких відносить електронні докази до речових (Німеччина) або до письмових доказів (Франція, Італія) [4].

Однак, все ж таки більше представників іншого підходу, які обґрунтовують необхідність виокремлення електронних засобів доказування серед інших засобів доказування (М.В.Горєлова, Т.В.Цюра). Так у своїй дисертаційній роботі Павлова Ю.С висловлює думку, що визначення електронних доказів як самостійних засобів доказування нарівні 3 письмовими та речовими $€$ безперечно одним з прогресивних досягнень нового ЦПК. Оскільки, до прийняття змін під час дослідження цифрової інформації через відсутність в процесуальних кодексах такого виду доказів як електронні, суди були змушені 
відносити звуко- й відеозаписи до речових, а електронне листування, електронні документи до письмових, що ускладнювало порядок дослідження та оцінку таких доказів в цивільному процесі [3].

Ще одним проблемним питанням $€$ те, що багато вчених не погоджуються із визначенням «електронні докази». У ст.101 ЦПК закріплено таке визначення даного поняття: «електронними доказами $\epsilon$ інформація в електронній (цифровій) формі, що містить дані про обставини, що мають значення для справи, зокрема електронні документи (в тому числі текстові документи, графічні зображення, плани, фотографії, відео- та звукозаписи тощо), вебсайти (сторінки), текстові, мультимедійні та голосові повідомлення, метадані, бази даних та інші дані в електронній формі.» На думку Гусєва О.Ю, таке визначення $€$ не досить вдалим, оскільки в першій частині воно так і не розкриває походження доказів, а в другій непослідовно перераховуються окремі види цифрових даних і змішуються з їх джерелами. Він пропонує своє визначення електронних доказів, а саме: «Електронні докази - це електронна (цифрова) інформація, одержана з дотриманням порядку, встановленого законом, що містить відомості по факти та обставини, які мають значення для розгляду справи.» [2]. Проте на нашу думку, таке визначення також не $є$ вдалим, оскільки окреслює лише його загальні ознаки, тобто формує лише загальне уявлення про електронні докази, що в подальшому призведе до плутанини та не одностайності суддів при визначенні відноситься той чи інший доказ до цієї групи, чи ні.

Варто зауважити, що судова практика $€$ неоднозначною у вирішенні питаннях, які саме електронні докази (у якій формі, на якому носієві тощо) вважати допустимими засобами доказування. Так значна частина судів першої інстанції не беруть до уваги роздруківки з мережі Інтернет, оскільки в соціальних мережах може зареєструватись будь-яка особа, а тому зазначене ім'я чи логін не дає можливості ідентифікувати особу. Інша частина навпаки вважає за можливе і правомірне використовувати досліджувані докази як належні у судовому засіданні [1].

3 прийняттям змін до ЦПК досить спірними залишились питання, пов'язані з електронними доказами, розміщеними в Інтернет - мережі. До ЦПК було включено положення, що суд за заявою учасника справи може оглянути вебсайт, інші місця збереження даних у мережі Інтернет з метою встановлення та фіксування їх змісту. Однак яким саме чином суддя повинен фіксувати зміст електронного доказу та фракт його розміщення в мережі Інтернет чітко не регламентовано [3]. Крім того, зважаючи на вразливу природу таких доказів, заінтересовані особи можуть втрутитись до їх змісту або повністю виділити 3 глобальної мережі.

Отже, підбиваючи підсумку можна сказати, що закріплення в Цивільнопроцесуальному кодексі електронних доказів як самостійних засобів доказування нарівні з письмовими та речовими $є$ позитивним досягненням, оскільки поступово електронні ресурси стають основним джерелом інформації, підтвердженням чому $є$ досвід технологічно розвинутих країн. Однак інститут електронних доказів потребує подальшого вдосконалення, що пов'язане зі специфікою електронних доказів та відсутністю судової практики застосування відповідних норм. 


\title{
Список використаних джерел:
}

1. Гетьманцев, М. (2019). Електронні докази в цивільному процесі: Практика застосування новел законодавства. Підприємництво, господарство і право №2 , 19-23 Вилучено 3 http://pgp-journal.kiev.ua/archive/2019/2/5.pdf.

2. Гусєв, О. Ю. (2019). Проблеми визначення поняття електронних доказів на прикладі цивільного процесуального кодексу України. Молодий вчений, 6(70), 124-128. Вилучено 3 http://molodyvcheny.in.ua/files/journal/2019/6/26.pdf.

3. Павлова, Ю. С. (2019). Електронний документ як джерело доказів у цивільному процесі (дис. ... канд. юрид. наук). Одеса, Україна. Вилучено з http://hdl.handle.net/11300/11724.

4. Петренко, В. С. (2018). Електронні докази як елемент інформаційних технологій у цивільному судочинстві. Молодий вчений, 1(53), 111-115. Вилучено 3 http://molodyvcheny.in.ua/files/journal/2018/1/27.pdf.

\section{ВПЛИВ ПРОЦЕСІВ ГЛОБАЛІЗАЦІЇ НА МІЖНАРОДНЕ ПРИВАТНЕ ПРАВО}

\author{
Махно Катерина Олексіївна \\ здобувач вищої освіти юридичного факультету \\ Дніпровський національний університет імені Олеся Гончара
}

Науковий керівник: Марков Карло Анатолійович

д-р. іст. наук, професор, професор кафедри європейського та міжнародного права

Дніпровський національний університет імені Олеся Гончара

УКРАЇНA

Територія, так чи інакше, обов'язково виступає важливим знаменником транскордонної взаємодії між національними правовими системами, що кожного дня набуває все більшого розмаху, а тому існує чітка матеріальна спорідненість між міжнародним приватним правом та правовими вимірами глобалізації.

Глобалізація - це процес взаємодії та інтеграції між людьми, компаніями та урядами різних країн, процес, що стимулюється міжнародною торгівлею та інвестиціями, інформаційними технологіями. Цей процес впливає на навколишнє середовище, на культуру, на політичні системи, на економічний розвиток і, звісно, на правові системи [1].

Міжнародне приватне право - це галузь права, яка складається з принципів та правил розгляду судових спорів, які мають іноземний елемент: наприклад, транскордонні справи про розлучення або транснаціональні комерційні спори. Таким чином, терміни "міжнародне приватне право" та "колізійне право" взаємозамінні.

Глобалізація та міжнародне приватне право - це явища, які мають спільне коріння, як щодо сфери відповідних норм, так і у контексті та термінології локалізму та екстерналізму. Складність та всеохоплюючий характер глобалізації створюють сучасні проблеми, і саме помітне розширення сфери міжнародного приватного права для задоволення сучасних реалій швидко 
глобалізуючого світу відповідає світовим тенденціям, в яких транснаціональні закони постійно опиняються у фокусі уваги, незалежно від того, як часто вони застосовуються в місцевих судах. Сфера місцевих (внутрішньодержавних) законів дедалі більше перетинається з публічним надбанням, пов'язаним також і з міжнародним приватним правом.

Найясніший вираз походження глобалізації в транскордонних комунікаціях можна знайти у сфері міжнародного співробітництва правоохоронних органів, а в комерції - у сфері міжнародних комерційних спорів. Транскордонні ситуації, що виникають, будь-якого характеру: чи то суперечок чи то іншого (наприклад, правовідносини у сфері публічного регулювання компаній), як правило, хоча і не розглядаються в межах міжнародного приватного права, але вони мають характер сучасних колізійних норм у дії та супроводжуються найчастіше спеціалістами у сфрері приватного міжнародного права [2]. Тому, вплив глобалізації на міжнародні нормативно-правові акти не можна заперечувати, оскільки він дійсно відчутний та глибокий.

Зв'язок між міжнародним приватним правом та глобалізацією полягає у їх взаємному реагуванні на відносну залежність усіх правових систем. Кожна норма міжнародного приватного права потенційно має глобальний географічний простір, виявляючи змінну правову відповідь на всю поширеність глобалізації.

Цікавим питанням $є$ і сучасне місце держав та державних органів у міжнародному приватному праві. Держави дійсно цікаві тим, що вони змінюються в так званому глобальному порядку як сторони звичайних цивільних угод та спорів, як суб'єкти міжнародного приватного права. Відбувається ерозія провінційності державності в глобальну епоху.

Сьогодні внутрішньодержавне законодавство рідко коли охоплює тільки власне внутрішньодержавне. Цей список можна поповнити і регіональним законодавством, і міжнародним.

Міжнародне приватне право потребує формування та застосування міжнародно-правових кодексів для диверсифікованого світу. Кодекси, які будуть укладені з урахуванням норм міжнародного публічного права, оскільки деякі правовідносини випливають саме з нього (наприклад, правовідносини у сфрері міжнародної торгівлі).

Глобальні зміни сьогодення потребують постійного прогресу міжнародного права загалом, та міжнародного приватного права зокрема, щоб відповідати сучасним правовим вимогам.

\section{Список використаних джерел:}

1. Бірюков, Р. М. (2009). Глобалізація та її вплив на правову сферу. Порівняльно-правові дослідження, 36-40. Вилучено http://dspace.nbuv.gov.ua/bitstream/handle/123456789/18375/06-Biryukov.pdf?sequence=1.

2. Панченко, С. В. (2005). Місце колізійних норм міжнародного приватного права у системі норма права. Правова держава, (8), 60-64. Вилучено 3: http://dspace.onu.edu.ua:8080/bitstream/handle/123456789/3005/2005_08.6064\%2B.pdf?sequence=1\&isAllowed=y. 


\section{ДО СТАНУ РОЗРОБКИ ПРОБЛЕМИ АЛЬТЕРНАТИВНИХ ЗАСОБІВ РОЗВ'ЯЗАННЯ КРИМІНАЛЬНО-ПРАВОВОГО КОНФЛІКТУ}

Сімонцева Людмила Олександрівна

старший викладач кафедри галузевого права

Херсонський державний університет

УKPAÏHA

Формування сучасної концепції кримінального покарання та його реалізації засобами кримінального процесу вимагає наявності належного теоретичного підґрунтя. Загальновідомо, що застосування альтернативних засобів вирішення кримінально-правового конфлікту виступає предметом дослідження багатьох зарубіжних учених. При цьому, інтерес викликає і сучасна українська наукова позиція щодо можливостей та перспектив застосування цього інституту. Не беручи на себе задачу висвітлити усі роботи, нам хотілося б звернути увагу на найбільш цікаві 3 них, які стосуються безпосередньо предмету нашого дослідження та характеризують напрямок розвитку вітчизняної кримінально-процесуальної доктрини з цього питання.

Окремі види альтернативних засобів вирішення (розв'язання) кримінальноправового конфлікту у кримінальному процесі розглянуті у дослідженні О.А. Губської «Процесуальні питання звільнення особи від кримінальної відповідальності за нереабілітуючими обставинами» (2002р.) [1]. В роботі вперше у кримінально-процесуальній науці незалежної України на рівні монографічного дослідження було запропоновано застосування органами слідства нових обставин звільнення особи від кримінальної відповідальності дійове каяття і примирення обвинуваченого з потерпілим та відзначено, що інститут звільнення від кримінальної відповідальності у зв'язку з дійовим каяттям доцільно поширити і на справи про злочини середньої тяжкості.

Привертає увагу й робота В.Т. Маляренка «Перебудова кримінального процесу України в контексті європейських стандартів: теорія, історія і практика» (2005 р.) [2], в якій автор присвячує підрозділ відновлювальному правосуддю як перспективній і ефективній складовій кримінального процесу. Співзвучним цьому питанню виступає дослідження О.€. Соловйової «Примирення сторін у кримінальному процесі України» (2006 р.) [3], в якому предметом дослідження виступає правове регулювання процесуального порядку звільнення особи від кримінальної відповідальності у зв'язку 3 примиренням обвинуваченого (підсудного) з потерпілими. Авторка вважає, що примирення сторін $€$ інструментом врегулювання кримінально-правових конфліктів і повинно розглядатися як самостійне провадження з залученням до вирішення справи посередника (медіатора) з наділенням його відповідним процесуальним статусом.

3 протилежною позицією можливо ознайомитися у дослідженні Ю.І. Микитина, який оцінюючи міжнародний досвід та перспективи розвитку 
відновного правосуддя у кримінальному процесі (2010р.) [4] сформулював авторське поняття відновного правосуддя, та визначив, що медіація у системі стадій кримінального процесу повинна займати місце факультативної процедури, яка не може застосовуватися до всіх категорій кримінальних справ. Відповідну позицію підтримує також і Аракелян Р.Ф., яка займалася вивченням впровадженням інституту медіації в кримінальне процесуальне законодавство України у 2019 році [6]

Відповідно, приходимо до висновку, що альтернативні засоби розв'язання кримінально-правового конфлікту розглядаються українськими процесуалістами як важливий елемент відновної моделі судочинства, яку слід запроваджувати в Україні. Водночас, стає зрозумілим, що сама модель судочинства до сих пір викликає у дослідників запитання, оскільки вони не можуть вирішитися 3 місцем в ній альтернативних засобів вирішення кримінально-правового конфлікту. У зв'язку з цим слід говорити про необхідність подальших наукових розвідок у цій сфері.

\section{Список використаних джерел:}

1. Губська, О. А. (2002) Процесуальні питання звільнення особи від кримінальної відповідальності за нереабілітуючими обставинами (автореф. дис... канд. юрид. наук). Київ. нац. ун-т ім. Т.Шевченка. Київ, Україна

2. Маляренко, В. Т. (2005) Перебудова кримінального процесу України в контексті європейських стандартів: теорія, історія і практика: (автореф. дис... д-ра юрид. наук). Нац. юрид. акад. України ім. Я.Мудрого. Харків, Україна.

3. Соловйова, О. Є. (2006) Примирення сторін у кримінальному процесі України (автореф. дис... канд. юрид. наук). Харк. нац. ун-т внутр. справ. Харків, Україна.

4. Микитин, Ю. І. (2010) Відновне правосуддя у кримінальному процесі: міжнародний досвід та перспективи розвитку в Україні. (автореф. дис. ... канд. юрид. наук). Нац. акад. прокуратури України. Київ, Україна.

5. Аракелян, Р. Ф. (2019) Впровадження інституту медіації в кримінальне процесуальне законодавство України. (дис. ... канд. юрид. наук). Вищий навчальний заклад «Національна академія управління»; Університет державної фіскальної служби України. Київ, Україна.

\section{ЗАСТЕРЕЖЛИВІ ЗАУВАЖЕННЯ ЩОДО ПРОЦЕСУ ДЕСОЦІАЛІЗАЦІЇ У СВІТІ ПРАЦІ}

Гладкий В'ячеслав В'ячеславович

аспірант Навчально-наукового інституту права ім. князя Володимира Великого Міжрегіональна академія управління персоналом

УКРАÏHA

3 моменту розпаду колишнього СРСР та з відновленням незалежності України в нашій державі відбувались фундаментальні цивілізаційні зрушення. Між тим, ця поспішна цивілізаційна перебудова держави, суспільства та індивідів, котрі наївно осмислювали власні перспективи у нових ринкових умовах, як перспективи чергового, утім, вже умовно декомунізованого 
«світлого майбутнього», відбувалась на тлі відсутності належного досвіду публічного врегулювання приватних та публічних правовідносин за новим напрямком розвитку держави. Цілком очевидно, що не співпадіння цивілізаційних прагнень держави та можливостей йти відповідним шляхом призводило до відповідного дисонансу правопорядку, чим скористались низка недобросовісних громадян та злочинних угрупувань, протиправна активність яких обумовила соціальну катастрофу (у вимірі криміналізації суспільства) та загострила рівень правового нігілізму в суспільстві, який знецінював (фактично на всіх рівнях) ідею вибудовування держави в межах нової цивілізаційної людиновимірної парадигми. Утім, слід констатувати, що вказані проблеми поступово вирішувались шляхом побудови соціальної, правової та демократичної держави.

Поряд із тим, вже починаючи з вересня 2019 р. в Україні розпочався стрімкий процес комплексної десоціалізації ще не сформованої моделі соціальної держави загалом та десоціалізації трудової діяльності державних службовців (окремо - прокурорів), зокрема. На підставі цих дій, які неодмінно призведуть до погіршення рівня соціальної безпеки громадян, розширення класу прекаріатів та андеркласу загалом, а також зумовить утвердження панування корупції у державі, виникає потреба в науковому осмисленні концепції гідної праці, що нівелюється відповідними антисоціальними процесами.

Не викликає жодних заперечень постулат, яким стверджується, що на сьогоднішній день будь-яка держава «потребує висококваліфікованих працівників, які будуть відповідати сучасним вимогам, що висуваються на ринку праці» [1]. Це обумовлено тим фрактом, що «розвиток держави значної мірою залежить від того, як саме її громадяни виконують свої професійні обов'язки» [2], а особливо - на публічній (зокрема, державній) службі. Вказане $€$ цілком очевидним, приймаючи до уваги те, що саме люди (або ж людський капітал) здатні надати підприємствам (установам, організаціям) необхідні для них вирішальні конкурентні переваги на сучасному ринку. Нерозуміння цього очевидного фракту, як правило, $є$ результатом: (1) обумовлених існуючими традиціями нецивілізованих взаємовідносин між сторонами договору загалом чи між сторонами трудового договору, зокрема (проблема нецивілізованості акторів на ринку); (2) нерозуміння принципів нормальних взаємовідносин між людьми (юридично значима психологічна проблема, що виявляється у незрілості особистості чи її психопатологічних, патопсихологічних проблемах; ця проблема актуалізується з огляду на поширення психічних розглядів у людей та небезпечного перебігу психічних розладів в умовах низької соціальної безпеки [див., напр.: 3-4]); (3) бізнес-стратегії (може бути відображенням життєвої стратегії), за якої отримання будь-якого блага використовується шляхом "хижацької» експлуатації інших людей (юридично значима психопатична проблема). Усі ці проблеми (вони можуть бути також осмисленні й відносно недобросовісних працівників, що нечесно експлуатують ресурси роботодавців [див., напр.: 5-6]), на жаль, спричиняють появу в практичній дійсності т. зв. «хижацьких роботодавців», котрі використовують трудові правовідносини не за моделлю «кредитор ↔ боржник», а за моделлю «експлуататор $\rightarrow$ жертва». 
Окреслене спотворення одних з базових правовідносин для працездатної людини, що реалізує свободу праці у частині права на працю, як ми можемо спостерігати, спричиняє неминучий розпад інституту трудових правовідносин та викривляє соціальну спрямованість економіки. Як наслідок, збільшується соціальне напруження, а сама держава знаходиться під значним ризиком здійснення революцій, переворотів, знищення загалом. Це $\epsilon$ цілком закономірним 3 огляду на те, що соціальна держава ґрунтується на цивілізаційних ідеях та ідеалах, які вона втілює в об'єктивну дійсність. Одним 3 таких ідеалів $\epsilon$ людиновимірне трудове право, провідними ідеями якої $\epsilon$ соціальне партнерство й соціальна безпека працівників і роботодавців, гідна праця працівників, яка заснована на активному здійсненні працівником власної свободи праці, результатом якої $є$ певна соціальна користь. Ці ідеї $€$ фундаментальними, цивілізаційними ідеями, у тій чи іншій мірі спрямованими на захист сьогочасної найвищої соціальної цінності у сфері праці (цією цінністю $€$ не виробництво, як за часів заводського та фабричного права, а людина, її життя та здоров'я). Відповідно, недостатність впровадження державою цивілізаційних концепцій (соціальної безпеки, гідної праці, свободи праці, соціального партнерства і т. д.) чи їх часткове або ж повне ігнорування свідчить про недостатню цивілізаційну відповідність такої держави, для якої людина (ії життя, здоров'я) не розуміється в якості найвищої соціальної цінності. При цьому соціально-безвідповідальна держава ставить під загрозу соціальну безпеку працівників, а, відтак, провокує, як ми вже зазначали, соціальний конфрлікт у державі, що закономірно, адже громадяни за таких умов не розуміють сенсу у державі, котра лише продукує заборони, збирає податки та інші обов'язкові платежі, й не захищає при цьому громадян (а іноді, як вже нами раніше було продемонстровано, може становити собою самостійну загрозу для їх безпеки, як це відбулось, серед іншого в Радянській Україні у 19321933 рр. [див., напр.: 7]). Особливо проблематичним це питання виявляється в умовах перебування держави у воєнних конфліктах, адже за таких умов у громадян «вимивається» прив'язаність до власної держави, ототожнення 3 нею (це не обов'язково стосується до території, країни), яка є агресором та експлуататором стосовно них самих. Більш того, ображеність експлуататорською політикою держави часто призводить до того, що люди (громадяни цієї держави) можуть бути схильними до: (1) підтримки держави, котра вчинила акт агресії проти держави, громадянами якої вони $€$ (це $€$ особливо небезпечно для України, території якої ще перебувають у режимі тимчасової окупації); (2) рекрутування до злочинного світу; (3) залучення до існуючого «маховика корупції» (як ми вже зазначали, феномен корупції має місце в будь-якому суспільстві, але в найбільш поширеному та агресивному вигляді спостерігається в суспільствах з низькою культурою [8]).

Окреслене $є$ цілком зрозумілим в контексті соціально-правової значимості праці, а також трудової діяльності, скорегованої концепцією гідної праці, що можна конструктивним чином осягнути проаналізувавши це питання в суто антропологічному та загальному історичному контекстах. Зазначимо, що праця, як така, ще з давніх часів складала собою питання, котре людством розумілось в якості одного «з найважливіших для подальшого розвитку цивілізації» [9]. Так само з давніх часів серед людей постало й питання про безпеку праці, що ґрунтувалось переважно на раціональній, а не на певній 
протогуманістичній (при цьому сам гуманізм $є$ виявом раціоналізму) логіці. Звісно, не можна стверджувати про те, що вже у давні часи люди вже виробили основи безпеки та охорони праці, сформулювали стандарти гідної праці та гідних взаємовідносин між найманим працівником і наймодавцем (щонайменше, це твердження було би некоректним навіть у тому сенсі, що відповідних відносин на той час у сьогочасному їх розумінні ще не існувало; крім того, вказане не виливає з бажання сформулювати т. зв. «оригінальну теорію», адже, як відомо, просте бажання сформулювати оригінальну наукову думку не повинне шкодити цінності наукової істини, шляхом культивування білянаукових думок, що маскуються в якості наукових гіпотез й засмічують чистоту науки, стримують розвиток людства). Проте, не можна й заперечувати того, що в часи, коли людське життя та здоров'я не було вищою соціальною цінністю, воно не було певною цінністю, яке мало реальне, натуральне значення, що визначалось призмою тогочасної вищої соціальної цінності нормального функціонування перших суспільств та їх «вождів». Загалом, в окресленому питанні слід виходити з того, що соціально-правові феномени, як такі, не виникають одноманітно, а формуються протягом певного періоду часу (іноді сторіччями, як це можемо спостерігати на прикладі трудового права [див., напр.: 10]), а певні еволюційні форми конкретного феномену вже можуть розглядатись в якості цього френомену з відповідним врахуванням того, що розглядувана еволюційна форма явища не може розглядатись в якості повноцінної форми феномену (й до неї, таким чином, не можуть висуватись ті ж вимоги, що й до повноцінної форми).

Більш того, слід зауважити, що з вказаним у тій чи іншій мірі погоджуються також й інші вчені. Зокрема, українська вчена М. В. Данилова зауважує, що ще на початку розвитку цивілізації (приймаючи до уваги положення Зводу законів Хаммурапі, Законів Ману) «люди вже мали чітку уяву про взаємний зв'язок з працею та її охороною» [11]. Це, на нашу думку, вказує на те, що важливість безпечних умов праці були очевидними навіть для людини вже у стародавні часи. Цілком закономірною в цьому є наступна логіка:

(1) негідний людської природи підхід (настільки, наскільки цю природу могли осмислювати люди того часу) до управління трудовим ресурсом був осмислений «роботодавцями», як такий, що шкодить виробничим відносинам та меті «найму» осіб, іншим цілям: (а) шкідливі умови праці обумовлювали нещасні випадки під час виконання трудової діяльності, а отже призводили до скорочення трудового ресурсу та, таким чином, - до зменшення силової могутності перших державних утворень (ймовірно, ця логіка вже мала місце й у первісних додержавних суспільства), яку складали як чоловіки (котрих можна було мобілізувати), так і жінки (хоча жінки не брали участі в силових протистояннях між племенами та іншими групами людей, утім, відігравали важливу гуманітарну та відтворювальну роль в житті відповідної групи людей); (б) надмірне експлуатування людини призводило то того, що «працівник» не встигав відновлювати свій психофізіологічний трудовий потенціал, а, відтак трудовий ресурс експлуатованих осіб вже не міг бути настільки ж ефективним, що й раніше (на початку надмірної експлуатації чи до цієї експлуатації);

(2) негідний людської природи підхід до управління трудовим ресурсом був осмислений «працівниками», як такий, що безпосередньо суперечить базовим інстинктам людини, а саме: (а) інстинкту свободи (пригнічення трудовою 
діяльністю та в трудовій діяльності призводить до звуження свободи працюючої особи, що суперечить природі людини; саме тому, рабська та кріпосна праця економістами визначалась в якості неефективної, а на таку працю, зокрема, вже за часів Римської імперії вільні особи погоджувались, будучи змушеними до набуття відповідного юридичного стану скрутними життєвими обставинами); (б) інстинкту самозбереження (людина, психологічній стан якої вважається нормальним чи близьким до норми, уникає ситуацій, за яких вона може пошкодити собі здоров'я чи загинути, а тому, умови праці, в яких людина могла загинути чи зазнати каліцтва - у стародавні часи це було практично рівнозначно тому, що й загинути - не могли вважатись привабливими для людини, а тому, на ці умови працездатна особа погоджувалась, перебуваючи у вкрай відчайдушному стані).

Осмислюючи викладене, можемо констатувати, що у загальній формі логіка забезпечення людини безпечною працею не змінилась, хоча еволюція людського розуміння індивіду, суб'єктності людини, суб'єктності суспільства, участі індивіда в житті суспільстві, а також ускладнення моделі співжиття людей зумовило формування більш складної моделі гідної праці, ускладненою також технічними та іншими ресурсними можливостями людини забезпечити гідну працю.

В окресленому загальному сенсі гідна праця сьогодні - це праця вищого порядку, який відповідає: (1) потребам суспільства в цивілізованій участі людей в суспільному житті шляхом трудової діяльності, здійснення якої не соромило би суспільство; (2) потребам держави у трудовій активності людей, яка би сприяла підвищенню економічної активності в державі й не обумовлювала би інвалідизацію працездатних осіб, адже це збільшуватиме обсяг витрати соціальної держави на підтримку людей з інвалідністю та втрату одиниці трудового ресурсу (особливо, коли в державі відсутня цивілізована політика підтримки осіб з інвалідністю), що впливає на економічний потенціал держави (особливим чином це відчувається, коли негідна праця має масовий характер); (3) потребам держави у тому, щоби усі працездатні особи були зайняті тоді, коли вони не спроможні чи не бажають бути самозайняті суспільно корисною працею, оскільки, незайнятість обумовлює бідність, злиденність й підвищує рівень криміналізації суспільства [див., напр,: 12]; (4) базовому рівню осмислення гідності людини; (5) базовим потребам людини й блокуватиме віктимний, девіантний потенціал людини, зокрема, щодо використання місця роботи та/або робочого місця, службового становища та/або можливостей в неправомірному (чи в суто недобросовісному) руслі (щонайперше, для корупційної практики).

Цю ж позицію у тій чи іншій мірі поділяє директор Бюро МОП Полін БарретРід (Pauline Barrett-Reed), наголошуючи на тому, що праця загалом є «засобом підтримки життя та задоволення основних потреб людини», а гідна праця більш глибоке, комплексне поняття, яким охоплюються найважливіші якісні характеристики, головним чином: нормальні умови, в яких ця праця здійснюється; адекватні зарплата та соціальний захист найманого працівника; відсутність дискримінації та переслідувань на робочому місці; можливість реалізувати власне право голосу [13].

Відтак, приймаючи до уваги викладене, доходимо думки, що процес десоціалізації сфери праці (як у приватному, так і в публічному секторах) має 
бути зупинений та відмінений, як такий, що спричиняє значні соціальні ризики для громадян, провокує подальший розквіт корупції у державі, яка в умовах наявних безпекових загроз стає чинником, що обумовлює розпад держави (а це недопустимо ні за яких обставин). Окреслені зауваження, на нашу думку, можуть бути враховані у процесі розробки та прийняття Закону України «Про приведення сфери праці до стандартів гідної праці», а сама концепція гідної праці має стати основобудівною цивілізаційною ідеєю у триваючому процесі реформування чинного законодавства України про працю.

У цьому контексті слід уточнити, що у суто трудоправовому сенсі сьогочасна концепція гідної праці може осмислюватись у наступних двох контекстах:

(1) елементарний контекст гідної праці, що розкриває структуру концепції гідної праці, набір елементів світу праці, наявність яких характеризує працю та $\epsilon$ достатньою умовою для визначення праці в якості формально гідної чи негідної. При цьому, елементарний контекст гідної праці охоплює: (а) доступ до трудової діяльності (враховуючи також виникнення належного обсягу правосуб'єктності, який дозволяв би скористатися цим доступом) виникнення відносин з приводу виконання трудових функцій; (б) трудову діяльність працівника, особливості її перебігу (призупинення, зупинення, відновлення, припинення, поновлення; застосування заходів заохочення та заходів юридичної відповідальності і т. д.); (в) умови, в яких ця трудова діяльність здійснюється працівником; (г) соціально-правові можливості працівника, що йому надаються трудовою діяльністю, якою він займається, серед іншого, гарантії, якими володіє працівник у результаті наявності в нього трудової правосуб'єктності, реалізації ним свободи праці і т. д.;

(2) якісний контекст гідної праці, котрий характеризує якість структури концепції гідної праці, дозволяючи ту чи іншу комбінацію елементів світу праці, що складають елементарний контекст гідної праці, оцінити як такі, що спроможні трудову діяльність працівника робити якісно гідною. У такому сенсі, приміром, трудова діяльність працівника має бути вільною (непримусовою), законною діяльністю, а так само і соціально корисною (чи соціально допустимою), стандартною (типовою, традиційною), здійснюваною в межах трудових правовідносин, що виникли на підставі трудового договору і т. д.

\section{Список використаних джерел:}

1. Гаврилюк, В. О. (2019). Правове регулювання стажування працівників (дис. ... канд. юрид. наук). Київ.

2. Шопіна, І. М. (2003). Щодо визначення поняття ефективності професійної діяльності слідчих ОВС України. Право і безпека, 2(3), 160-164.

3. Гладкий, В. В. (2019). Реальность в свете аффрективных расстройств: пример тревожнодепрессивных расстройств. Наукові теорії сьогодення та перспективи розвитку наукової думки: матер. міжнар. наук. конф. (Т. 2, с. 46-50), 11 жовт. 2019 р. Київ, Україна: МЦНД. DOI: $10.5281 /$ zenodo.3483467.

4. Пузанова, В.В. (2019). Лица с обсессивно-компульсивным расстройством в свете пятифакторной модели личности. Наукові теорії сьогодення та перспективи розвитку наукової думки: матер. міжнар. наук. конф. (Т. 2, с. 27-32). 11 жовт. 2019 р. Київ, Україна: МЦНД. DOI: 10.5281/zenodo.3483486. 
5. Гладкий, В. В. (2018). Працівники-шахраї та їх вплив на ефективну діяльність підприємств. Пріоритети розвитку підприємств у XXI столітті: матер. Міжнар. наук.-практ. конф. (с. 198-199). 22 листоп. 2018 p. Кропивницький, Україна: РВЛ ЦНТУ. DOI: 10.5281/zenodo. 1486273 .

6. Гладкий, В.В. (2019). Профессиональное мошенничество и его виды. Сучасні тенденції розбудови правової держави в Україні та світі: матер. VII Міжнар. наук. конфр. (с. 330-332). 18 квіт. 2019 р. Житомир Україна: ЖНАУ.

7. Гладкий, В. В. (2009). Кваліфікація Голодомору, як злочину геноциду проти Українського народу. Актуальні проблеми міжнародних відносин, 83(2), 166-172. DOI: 10.17721/apmv.2009.83.2.166-172.

8. Hladky, V. V. (2019). The Structure of the System of Corruption Crime Subjects according to the Legislation of Ukraine. Path of Science, 5(4), 2008-2021. DOI: 10.22178/pos.45-4.

9. Спіцина, Г.О.(2016). Сучасні тенденції правового регулювання праці в Україні та країнах Європейського Союзу (дис. ... д-р. юрид. наук). 12.00.05. Харків.

10. Пузанова, В. В. (2019). Зміна трудового договору в епоху дотрудового права України. Право, держава та громадянське суспільство в умовах системних реформ: матер. наук.-практ. конфф. (с. 14-17), 22-23 лют. 2019 р. Дніпро, Україна. Херсон: Молодий вчений.

11. Данилова, М.В. (2019). Проблеми співвідношення охоронних та організаційноуправлінських відносин у трудовому праві (дис. ... д-р. юрид. наук). Київ.

12. Гладкий, В. В. (2017). Бедность, нищета и криминализация общества. Актуальные научные исследования в современном мире, 6-6(26), 35-55. DOI: 10.5281/zenodo.572330.

13. Баррет-Рид, П. (2003). Неотьемлемые признаки достойного труда. Человек и труд, (3), 4-10.

\title{
ЗУСТРІЧНЕ ЗАБЕЗПЕЧЕННЯ ПОЗОВУ В ЦИВІЛЬНОМУ ПРОЦЕСІ
}

\author{
Гердова Кристина Олександрівна \\ студентка 4 курсу \\ Дніпровський національний університет імені Олеся Гончара
}

Науковий керівник: Резникова М. О.

канд. юрид. наук доцент

Дніпровський національний університет імені Олеся Гончара

УКРӒ̈HA

На сьогоднішній день в цивільному процесі України функціонує інститут забезпечення позову, метою якого $є$ забезпечення законних прав та інтересів осіб, які звертаються за судовим захистом, і виконання позовних вимог у майбутньому. 3 жовтня 2017 року Верховною Радою України був прийнятий Закон України «Про внесення змін до Господарського процесуального кодексу України, Цивільного процесуального кодексу України, Кодексу адміністративного судочинства та інших нормативно-правових актів». Однією з основних новел Цивільного процесуального кодексу України є впровадження зустрічного забезпечення, як механізму захисту прав відповідача. 
Дослідженню проблемних аспектів фрункціонування інституту зустрічного забезпечення позову та його правовому регулюванню в цілому присвячені праці таких науковців, як Островська Л. А., Бут І. О., Шурин О. А., Гопкін П. В., Алєксєєва Н. С. та інших.

Відповідно до ч. 1 ст. 154 ЦПК України метою інституту зустрічного забезпечення позову $є$ забезпечення відшкодування збитків відповідача, які можуть бути спричинені забезпеченням позову. Тобто зустрічне забезпечення застосовується тільки у випадку забезпечення позову [1].

Проаналізувавши норми ЦПК України, можна стверджувати, що за загальним правилом застосування зустрічного забезпечення є дискреційним повноваженням суду. Проте суд зобов'язаний застосовувати зустрічне забезпечення, якщо: 1) позивач не має зареєстрованого в установленому законом порядку місця проживання (перебування) чи місцезнаходження на території України та майна, що знаходиться на території України, в розмірі, достатньому для відшкодування можливих збитків відповідача, які можуть бути спричинені забезпеченням позову, у випадку відмови у позові; або

2) суду надані докази того, що майновий стан позивача або його дії щодо відчуження майна чи інші дії можуть ускладнити або зробити неможливим виконання рішення суду про відшкодування збитків відповідача, які можуть бути спричинені забезпеченням позову, у випадку відмови у позові [1].

Гарієвська М. Б. звертає увагу на те, що обов'язкове зустрічне забезпечення існує в небагатьох країнах і передбачене щодо певного кола осіб, наприклад, іноземців, проте в окремих країнах це вважається порушенням ст. 6 Конвенції про захист прав людини і основоположних свобод щодо вільного доступу до суду, оскільки тут є певна дискримінація (доповідь AMП, ILA, 1996). Враховуючи зазначене, судам слід дуже ретельно перевіряти правові підстави та подані докази в разі застосування наведеної норми, а в разі сумніву - виносити питання в судове засідання [2].

Зустрічне забезпечення, як правило, здійснюється шляхом внесення на депозитний рахунок суду грошових коштів у розмірі, визначеному судом розмір зустрічного забезпечення визначається судом з урахуванням обставин справи. Заходи зустрічного забезпечення позову мають бути співмірними із заходами забезпечення позову, застосованими судом, та розміром збитків, яких може зазнати відповідач у зв'язку із забезпеченням позову. Оцінка співмірності здійснюється, крім іншого, з урахуванням співвідношення права та інтересу, які просить захистити заявник, вартості майна, на яке накладається арешт, або майнових наслідків заборони відповідачеві вчиняти певні дії [3].

Більшість вчених притримуються думки, що запровадження інституту зустрічного забезпечення позову розширить коло повноважень відповідача в сфрері захисту своїх прав та попередження можливому зловживанню позивача в ініціюванні та процесуальному лобіюванні заходів забезпечення позову [3]. Але на думку автора, з цією позицією важко погодитися, адже наразі ця новела надасть відповідачу більше можливостей зловживати своїми правами для безпідставного затягування чи перешкоджання розгляду справи. Тобто в даному випадку позивач, який i так $€$ постраждалою стороною, буде вимушений терпіти зайві витрати. 
3 огляду на те, що інститут зустрічного забезпечення позову, як і інститут забезпечення позову в цілому, $\epsilon$ сфрерою найбільш сприятливою для зловживання сторонами процесуальними правами та у зв'язку з наявною недобросовісністю його використання, Шурин О. А. у своїй праці пропонує доповнити ч. 2 ст. 44 ЦПК України (дії, які суд може визначити зловживанням процесуальними правами) таким положенням: «подання безпідставної, необґрунтованої заяви про забезпечення позову або заяви про зустрічне забезпечення позову» [4].

Також Луспеник Д. Д. звертає увагу на те, що для суддів є складним визначення розміру зустрічного забезпечення у разі, якщо вимога позивача носить майновий, а не грошовий, характер, тобто при заявленні вимог про визнання. Проект ЦПК України передбачає зустрічне забезпечення зі всіх видів позовів, не виділяючи позов про присудження чи позов про визнання. Тут суд повинен буде виходити зі своїх дискреційних прав та оціночних суджень і визначати розмір можливих збитків відповідача, завданих забезпеченням позову. Очевидно, що можливі збитки можуть включати в себе як збитки в їх класичному розумінні згідно з вимогами ст. 22 ЦК України, так і негативні наслідки, пов'язані з діловою репутацією, гідністю та честю [5].

Отже, запровадження до Цивільного процесуального кодексу України такої новели як зустрічне забезпечення позову розширило можливості відповідача у сорері захисту та убезпечення себе від необґрунтованих заходів забезпечення позову з боку позивача. Утім правове регулювання цього інституту залишається недосконалим, і потрібно звернути увагу, що його введення викликало ряд проблем як у сторін провадження, так і суддів. Саме тому на сьогоднішній день не можна стверджувати, що зустрічне забезпечення позову в цивільному процесі $є$ ефективним та доцільним.

\section{Список використаних джерел:}

1. Цивільний процесуальний кодекс України, № 1618-IV. (2004). Вилучено з https://zakon.rada.gov.ua/laws/show/1618-15.

2. Гарієвська, М.Б. (2018). Забезпечення майнових інтересів учасників справи в цивільному процесі: порівняльно-правовий аспект. Університетські наукові записки, № 67-68, 93-101.

3. Островська, Л. А. (2018). Зустрічне забезпечення позову як обов'язковий елемент інституту забезпечувальних заходів в цивільному процесі. Новели цивільного процесуального кодексу України: матеріали "круглого столу" (м. Одеса, 26 берез. 2018 р.), 37-40.

4. Шурин, О. А. (2018). Інститут забезпечення позову: теоретичні та практичні проблеми реалізації. Прикарпатський юридичний вісник, 1 (22), 177-180.

5. Луспеник, Д. Д. (2017). Зустрічне забезпечення. Кілька складних питань щодо застосування нового інституту, з якими стикнуться судді. Закон $і$ бізнес, № 34. Вилучено 3 https://zib.com.ua/ua/print/130073-

kilka_skladnih_pitan_schodo_zastosuvannya_zustrichnogo_zabez.html. 


\section{ІМПЛЕМЕНТАЦІЯ ЄВРОПЕЙСЬКОГО ПРАВА В НАЦІОНАЛЬНЕ ЗАКОНОДАВСТВО УКРАЇНИ}

Левкович Інна Володимирівна

здобувач вищої освіти юридичного фракультету Дніпровський національний університет імені Олеся Гончара

Науковий керівник: Чукаєва Вероніка Олександрівна канд. іст. наук, доцент, доцент кафедри теорії держави та права, конституційного права та державного управління Дніпровський національний університет імені Олеся Гончара УКРАЇ̈А

На сьогоднішній етап розвитку українського законодавства, ми переживаємо складний процес зміни правового устрою, адаптації до нових економічних та соціально-політичних умов. Україна знаходиться на шляху до вступу в Європейський Союз, який в свою чергу заснований на принципах демократії, так права людини і громадянина, безперечно, посідають провідне місце в запроваджених реформах. Невід'ємною складовою загального євроінтеграційного процесу $\epsilon$ інтеграція відповідних норм права, що передбачає поступове зближення і адаптацію національних правових систем - досягнення певного рівня узгодженості українського законодавства із сучасною європейською правовою системою або приведення у відповідність законодавства України до стандартів права ЄС. Питання адаптації законодавства України до законодавства Європейського Союзу та проблематики їх застосування на практиці активно досліджували у своїх працях: Г. Анцелевич, Н. Білошкурська, Н. Гнилюк, І. Грицяк, Г. Друзенко, В. Забігайло, О. Зеркаль, В. Костицький, О. Крупчан, А. Мацко, В. Опришко та iн. [1].

Адаптація законодавства України передбачає реформування ії правової системи та поступове приведення у відповідність із європейськими стандартами і охоплює приватне, митне, трудове, фінансове, податкове законодавство, законодавство про інтелектуальну власність, охорону праці, охорону життя та здоров'я, навколишнє природне середовище, захист прав споживачів, технічні правила і стандарти, транспорт, а також інші галузі, визначені Угодою про партнерство та співробітництво. Важливим чинником реформування правової системи України слід вважати участь України у конвенціях Ради Європи, які встановлюють спільні для цієї організації та ЄС стандарти.

Зважаючи на різноманітність точок зору дослідників стосовно класифікації європейських правових стандартів, необхідно зауважити, що класифікувати їх можна:

- за галузевою приналежністю;

- за суб'єктами їх створення;

- за зовнішньою формою закріплення;

- за юридичною значимістю;

- за дією на коло осіб; 
- за змістом можливостей;

- за видовою специфікою адресатів стандартизації;

- за способом реалізації.

Вагомим є той факт, що під час визначення класифікації європейських стандартів віддається перевага стандартам: у сфері прав людини та їх ефективного юридичного захисту [2]. Міжнародні соціальні стандарти становлять комплекс норм, які закріплені в міжнародно-правових актах, що визначають гідні умови життєдіяльності людей і спрямовані на забезпечення розвитку індивіда та на його соціальну захищеність. Ці соціальні стандарти повинні бути сприйняті законодавством кожної держави шляхом підписання та ратифікації міжнародних договорів, потім мають бути розвинені й пристосовані до існуючих у цій державі умов. Однак ці стандарти мають бути захищені й забезпечені не тільки законодавством держави, а й спеціальними ії інститутами.

Тому важливим гарантом реалізації соціальних прав є дієвий соціальний захист, який $є$ функцією перш за все суспільства, а не лише держави, забезпечення соціального становища людини, що склалося внаслідок дії соціальних ризиків і яке відповідає умовам, що органічно випливають з її невід'ємних і загальновизнаних соціальних прав, тобто міжнародних соціальних стандартів [4].

Реалізації соціальних прав громадян України сьогодні, на жаль, відбувається без належного на те правового забезпечення. Це виявляється в не системності правового регулювання у сфері соціального захисту, відсутності механізму забезпечення соціальної захищеності населення, невизначеності основних термінів законодавчими актами та довільну інтерпретацію соціальних стандартів народними депутатами України. Імплементація досвіду Європейського Союзу законодавства України вимагає додаткового дослідження й розроблення певних рекомендацій для забезпечення ефективного функціонування моделі інституту соціальної політики в державі. Основу новітнього інституту цієї політики ЄС формують концепти розвитку соціальної

держави й соціально орієнтованої ринкової економіки. Сутність ідеї соціальної політики, заснованої на концепції розвитку соціальної держави, визначається сукупністю інваріантних властивостей соціальних інститутів, якто: а) визнання соціальних прав громадян і взяття державою на себе соціальних зобов'язань; б) соціальна підтримка для всіх членів суспільства; в) існування державних систем

соціального захисту; г) взяття державою на себе відповідальності за рівень добробуту громадян; ґ) існування інститутів громадянського суспільства, зокрема, соціального діалогу [4].

Тлумачення положень міжнародного договору, по суті, це тлумачення юридичних норм, тому мають застосовуватися всі прийоми тлумачення, що відомі в теорії права і внутрішньодержавній практиці, за винятком таких, що суперечать суті міжнародного права, яке засноване на добровільній угоді суверенних суб'єктів. До цих прийомів відносяться: граматичне (словесне), логічне, історичне, систематичне і казуальне (тобто звичайне, практичне) тлумачення. Крім того, в системі тлумачення міжнародних договорів $€$ 
спеціальні принципи тлумачення, це загальні правила, яких необхідно дотримуватися як обов'язкових норм при тлумаченні міжнародних договорів [5].

Особливості тлумачення міжнародних договорів із прав людини зумовлені унікальною природою інституту прав людини як предмета інтерпретації, адже останні торкаються основних загальнолюдських цінностей. Так, Комітет ООН 3 прав людини, створений на підставі Міжнародного пакту про громадянські та політичні права для тлумачення Пакту, заявив, що «праву на життя занадто часто дається вузьке тлумачення. Вираз «невід'ємне право на життя» не може бути правильно зрозумілим, якщо його тлумачити обмежено, а захист цього права вимагає від держав прийняття конструктивних заходів» [5]. У межах Ради Європи (далі - Р€) прийнято низку документів, метою яких $€$ проголошення і гарантування основних прав людини на європейському континенті. Серед таких документів Європейська соціальна хартія.

У Європейському Союзі постійно здійснюється моніторинг додержання країнами встановленого рівня соціальних стандартів, й аналізуються соціальні процеси в соціумі з точки зору їх безпечності для суспільного розвитку й недопущення загострення соціальних суперечностей. До європейських соціальних стандартів рівня життя належать: показник очікуваної тривалості життя при народженні (від мінімального - 25 років до максимального - 85 років); показник грамотності дорослого населення (на рівні $100 \%$ ); середня тривалість навчання; сумарний коефіцієнт народжуваності; частка населення, яке проживає за межею бідності. Що стосується України, то на сьогодні рівень її соціальних стандартів суттєво відстає від європейського. Існують серйозні невирішені проблеми в соціальній сфері, а саме: а) низький рівень зайнятості й масовий характер безробіття; б) бідність; в) незадовільний рівень пенсій; г) посилення диференціації суспільства та ін. Вирішення економічних проблем країни позитивно вплине на рівень соціального захисту та забезпечення конституційних прав громадян України. Подолати наведені вище проблеми можливо у тому числі і шляхом удосконалення чинного законодавства України та його адаптації до європейських стандартів [4].

Отже, процес імплементації законодавства України до принципів права Європейського Союзу почався. Але необхідно визначити Національну програму щодо адаптації законодавства України до міжнародних стандартів у галузі прав людини, визначивши коло універсальних та регіональних конвенцій з прав людини, котрі в першочерговому порядку потребують ратифікації. Свідомість та прагнення самих громадян, адже задля успішного функціонування вищезазначених процесів, важливо вибудувати не тільки нормативно-правову базу, а й моральні орієнтири кожної людини зокрема.

\section{Список використаних джерел:}

1. К Каптанова, К. В. (2019). Адаптація законодавства України до законодавства Європейського Союзу. Актуальні проблеми державотворення, правотворення та правозастосування: матеріали наук. семінару (с. 139-140), 8 грудня 2018 р. Дніпро: ДДУВС.

2. Миколенко, В.А. (2017). Проблеми імплементації європейських стандартів функціонування національної правоохоронної системи. Науковий вісник Ужгородського національного університету. Серія: Право. 43(1), 77-80. 
3. Клименко А.Л.(2017) Міжнародно-правові стандарти соціального забезпечення. Трудове право; право соціального забезпечення - К., 2017. 29-30.

4. Собченко В.В.(2018). Європейські стандарти для реалізації соціальних прав громадян України. Публічне управління XXI століття: світові практики та національні перспектИвИ ЗБІРНИК ТЕЗ ХVIII МІЖНАРОДНОГО НАУКОВОГО КОНГРЕСУ (26 квітнЯ 2018 p)., 516-520.

\title{
ЛІНІЯ ЗАХИСТУ ЩОДО НЕЗАКОННОГО ЗВІЛЬНЕННЯ
}

\author{
Чепіга Дар'я Олександрівна \\ студентка 3-го курсу юридичного факультету \\ Дніпровський національний університет імені Олеся Гончара
}

Науковий керівник: Забродіна Олена Валентинівна кандидат політичних наук, доцент кафедри цивільного, трудового та господарського права Дніпровський національний університет імені Олеся Гончара

УКРӒ̈̈А

Питання врегулювання соціально-трудових відносин завжди було і буде актуальним, адже інтенсивне зростання економічних інтересів у суспільства, свідчить про важливість вчасного врегулювання трудових відносин, а інколи, попереджання незаконної поведінки з боку роботодавця, або працівника у тій чи іншій галузі трудових відносин.

Досить багато досліджень присвячується аналізу проблем розвитку та регулювання соціально-трудових відносин. Так, в роботах А. М. Колота і С. В. Мельника досліджуються соціально-трудові відносини в аспекті забезпечення стійкого розвитку національної економіки, надаються деякі рекомендації щодо вирішення проблеми оптимізації відносин між роботодавцями та найманими працівниками [2].

На думку автора, у разі, коли з'являється потреба у врегулюванні певної поведінки суб'єктів трудового права, то кожне проблемне питання чи неузгодженість слід розглядати окремо, і до того ж, спиратися перш за все на практику врегулювання цих відносин.

Найважливішим завданням трудового законодавства $є$ захист працівника від протиправної поведінки з боку роботодавця або перевищення меж його повноважень.

На превеликий жаль, частіше за все найманий працівник не обізнаний про свої права та законні інтереси, такою ситуацією користується несумлінний роботодавець. Тому, буває незаконне звільнення, недоречно підписаний строковий трудовий договір, безпідставна невидача заробітної плати більш ніж один місяць, та багато інших неправомірних дій з боку роботодавця. Як наслідок, потерпілі мусять звертатися до юристів, адвокатів з метою захисту свого порушеного права, закріпленого у статті 43 Конституції, згідно якої кожен має право на працю, що включає можливість заробляти собі на життя працею, яку він вільно обирає або на яку вільно погоджується [3]. 
Один із видів протиправної поведінки роботодавця, з якою стикається робітник, $є$ незаконне звільнення. Візьмемо до уваги та розглянемо ситуацію щодо незаконного звільнення з посади керівника певної державної установи за контрактом. У даному випадку, сторона захисту повинна розглянути питання щодо доцільності підписання контракту з особою такого статусу, а також яким чином будувати лінію захисту.

По-перше, відповідно до п. 6, 7 Постанови Кабінету Міністрів України «Про затвердження Порядку погодження з Головою Ради міністрів Автономної Республіки Крим, головами місцевих державних адміністрацій призначення та звільнення з посад керівників підприємств, установ та організацій, що належать до сфрери управління міністерств, інших центральних органів» від 09.10.2013 № 818 [4], а також, відповідно до ч. 2 ст. 36 Закону України «Про місцеві державні адміністрації», керівники підприємств, установ та організацій, що належать до сфери управління міністерств та інших центральних органів виконавчої влади, призначаються та звільняються з посад за погодженням 3 головою відповідної місцевої державної адміністрації крім керівників установ, підприємств і організацій Збройних Сил та інших військових формувань України, Міністерства внутрішніх справ України, Національної поліції, а також керівників навчальних закладів, що призначаються на посаду за умови конкурсу [5].

Таким чином, власник державної установи повинен надіслати пропозицію про погодження або вмотивовану відмову у погодженні на звільнення до обласної державної адміністрації та отримати відповідне повідомлення про погодження або вмотивовану відмову у п'ятиденний строк.

Разом з тим, відповідно до п. 1 Постанови Кабінету Міністрів України від 19 березня 1994 р. № 170 «Про впорядкування застосування контрактної форми трудового договору», контрактна форма трудового договору застосовується до працівників при прийнятті (найманні) на роботу, лише у випадках, прямо передбачених законами [6]. У зв'язку з чим, контракт укладається виключно у наступних випадках з наступними особами:

1) з керівниками підприємств незалежно від форми власності, як державних так і приватних (Постанова КМУ від 19.03.1993 р. №203 «Про застосування контрактної форми трудового договору з керівником підприємства, що $є$ у державній власності»);

2) з керівником закладу освіти, обраним (призначеним) упорядку, встановленому законодавством та установчими документами закладу освіти (Закон України від 05.09.2017 р. №2145-VIII «Про освіту»);

3) з працівниками біржі (Закон України від 10.12.1991 р. №1956-XII «Про товарну біржу»);

4) з науковцями (Закон України від 26.11.2015 р. №848-VIII «Про наукову i науково-технічну діяльність»);

5) з особами, залученими до роботи у фермерському господарстві (Закон України 19.06.2003 р. №973-IV «Про фермерське господарство»);

6) $з$ працівниками споживчих товариств, їх спілок та підпорядковані їм підприємства (Закон України від 10.04.1992 р. №2265-XII «Про споживчу кооперацію»);

7) з працівниками підприємств, установ та організацій у спеціальних (вільних) економічних зонах (Закон України від 13.10.1992 р. №2673-XII «Про 
загальні засади створення і функціонування спеціальних (вільних) економічних зон»);

8) з помічниками адвокатів (Закон України 05.07.2012 р. №5076-VI «Про адвокатуру та адвокатську діяльність»);

9) з особами, які здійснюють професійну діяльність у спорті (Закон України 24.12.1993 р. №3808-XII «Про фрізичну культуру і спорт»);

10) з працівниками залізничного транспорту загального користування, які здійснюють обслуговування пасажирів (Закон України від 04.07.1996 р. №273/96-ВР «Про залізничний транспорт»);

11) 3 іноземцями (Закон України від 05.07.2012 р. №5067-VI «Про зайнятість населення»);

12) з керівниками державних і комунальних закладів культури, а саме 3 керівниками державних та комунальних музеїв, керівниками державної чи комунальної бібліотеки, централізованої бібліотечної системи, з керівниками адміністрації історико-культурних заповідників, з директорами - художніми керівниками державного чи комунального театру та генеральним директором - художнім керівником національного театру, з професійними творчими працівниками державних та комунальних закладів культури (Закон України від 14.12.2010 р. №2778-VI «Про культуру»).

3 викладеного, слід звернути увагу, що контракт може укладатися 3 керівниками підприємств незалежно від форм власності, як державних, так і приватних, але, так як працівник, у нашому випадку, належить до категорії керівників державної установи, то законних підстав підписувати контракт з ним не має бути. Згідно до Державного класифікатора “Класифікація організаційноправових форм господарювання” (КОПФГ), що розроблено на виконання постанови Кабінету Міністрів України від 4 травня 1993 р. № 326 "Про Концепцію побудови національної статистики України та Державну програму переходу України на міжнародну систему статистики і обліку", об'єктом класифікації є визначені чинним законодавством організаційно-правові форми юридичних осіб та їх відокремлені підрозділи [11]. Відповідно до Державного класифікатора та чинного законодавства установа - це організація, що створена однією або кількома особами (засновниками), які не беруть участі в управлінні нею, шляхом об'єднання (виділення) їхнього майна для досягнення мети, визначеної засновниками, за рахунок цього майна. Підприємство - це самостійний суб'єкт господарювання, створений компетентним органом державної влади або органом місцевого самоврядування, або іншими суб'єктами для задоволення суспільних та особистих потреб шляхом систематичного здійснення виробничої, науково-дослідної, торговельної, іншої господарської діяльності в порядку, передбаченому цим Кодексом та іншими законами. Разом з тим, кожна позиція класифікатора структурно складається з тризначного ідентифікаційного коду та назви організаційно-правової форми господарювання. Ідентифікаційний код будується, використовуючи серійнопорядковий метод кодування. Початкові коди серій $(100,200,300,400,500$, 600,800 та 900) та їхні назви використовують для узагальнювання об'єктів класифікації і не призначені для безпосереднього кодування суб'єктів господарської та іншої діяльності. Код підприємств - 100, код Організації (установи, заклади) - 400. Дані обставини є доказом того, що державна установа не дорівнює державному підприємству. 
До того ж, у постанові Пленуму Верховного Суду України «Про практику розгляду судами трудових спорів» від 06.11.1992 р. № 9 передбачено, що власник або уповноважений ним орган може вимагати від працівника, який працює за трудовим договором, укладення контракту тільки в тому разі, коли він належить до категорії працівників, які згідно з законодавством працюють за контрактом [8].

Та слід зауважити, що на час прийняття Конституційним Судом України рішення від 09 липня 1998 року № 12-рп/98 термін "законодавство" [9], що вживається у частині 3 статті 21 Кодексу законів про працю України щодо визначення сфрери застосування контракту як особливої форми трудового договору, треба розуміти так, що ним охоплюються закони України, чинні міжнародні договори України, згода на обов'язковість яких надана Верховною Радою України, а також постанови Верховної Ради України, укази Президента України, декрети і постанови Кабінету Міністрів України, прийняті в межах їх повноважень та відповідно до Конституції України і законів України. На сьогодення діє Кодекс законів про працю України за редакцією від 04.09.2019 року, де у статті 21 КЗпП України вказано, що сфрера застосування контракту визначається «законами» України [1]. Таким чином, так як Постанова Кабінету Міністрів України «Про застосування контрактної форми трудового договору з керівниками підприємств, що $\epsilon$ у державній власності» $\epsilon$ підзаконним актом, то він не може надавати законної можливості власнику Державної установи укладати контракт з керівником [6].

Згідно з рішенням Конституційного Суду України від 09 липня 1998 року № 12-рп/98 контракт, як особлива фрорма трудового договору повинен спрямовуватися на створення умов для виявлення ініціативності та самостійності працівника, враховуючи його індивідуальні здібності й професійні навички, його правову і соціальну захищеність. Умови контракту, які погіршують становище працівника порівняно з чинним законодавством, угодами і колективним договором, вважаються недійсними (стаття 9 КЗпП України) (абзац перший пункту 5 мотивувальної частини).

Адже, таким чином відбувається необґрунтоване розширення сфери застосування контракту, яка виходить за межі, визначені законами України, актами Президента України та Кабінету Міністрів України. Це не сприяє створенню умов для повного здійснення права на працю, ускладнює становище працівників, знижує реальність гарантій трудових прав, встановлених Конституцією і законами України.

Незважаючи на застереження, що містяться в Кодексі законів про працю України та інших актах трудового законодавства та спрямовані на захист прав під час укладання трудових договорів у формі контрактів, сторонами в контракті можуть передбачатися невигідні для працівника умови: зокрема, це, тимчасовий характер трудових відносин, підвищена відповідальність, додаткові підстави розірвання договору тощо. Тому сфера застосування контракту під час оформлення трудових відносин не може бути безмежною.

Отже, у нашому випадку, укладення контракту законом не передбачено, а тому власник або уповноважений ним орган не має законних підстав укладати контракт з працівником. Тому, такий контракт вважається недійсним, в силу ст. 9 КЗпП України, як такий, що погіршує становище працівника порівняно 3 законодавством України. 
По-друге, відповідно до ст. 23 КЗпП України трудовий договір може бути безстроковим, що укладається на невизначений строк та строковий трудовий договір, який укладається на час виконання певної роботи. Та бувають ситуації, коли укладається строковий трудовий договір, який не мали право укладати з працівником в силу характеру його роботи.

У випадку підписання строкового трудового договору 3 керівником державної установи, це також $є$ порушенням норм законодавства. Тому, відповідно до ч. 2 ст. 23 КЗпП України строковий трудовий договір укладається у випадках, коли трудові відносини не можуть бути встановлені на невизначений строк з урахуванням характеру наступної роботи, або умов її виконання, або інтересів працівника та в інших випадках, передбачених законодавчими актами.

Згідно Постанови Кабінету Міністрів України від 28 березня 1997 р. № 278 «Про затвердження Списку сезонних робіт і сезонних галузей» сфери де трудові відносини не можуть бути встановлені на невизначений строк [10].

У зв'язку з чим, характер роботи керівника державної установи має постійний характер, адже робота керівника не може бути пов'язана із сезонними роботами, або такою, що укладається на визначений термін (на час виконання певної роботи), а це, у свою чергу, означає, що трудовий договір повинен укладатися на невизначений строк.

Підстави припинення трудового договору встановлено статтею 36 КЗпП України. Відповідно до пункту 2 частини першої статті 36 КЗпП України підставою припинення трудового договору є закінчення строку (пункт 2 і 3 статті 23), крім випадків, коли трудові відносини фрактично тривають і жодна із сторін не поставила вимогу про їх припинення. На цій підставі може бути припинений тільки строковий трудовий договір, укладений як строковий відповідно до закону. Якщо ж строковий трудовий договір укладено всупереч правилам статті 23 КЗпП України, то умова про строк $€$ незаконною. Трудовий договір у такому разі вважається укладеним на невизначений строк, і він не може бути припинений у зв язку із закінченням строку.

Разом з тим, відповідно до ст. 39-1 КЗпП України, якщо після закінчення строку трудового договору трудові відносини фактично тривають і жодна із сторін не вимагає їх припинення, дія цього договору вважається продовженою на невизначений строк. Та відповідно до ч. 2 ст. 39-1 КЗпП України, трудові договори, що були переукладені один чи декілька разів, за винятком випадків, передбачених частиною другою статті 23 КЗпП України, вважаються такими, що укладені на невизначений строк.

Отже, трудові відносини з працівниками не припиняються, якщо тільки не має законних підстав для такого припинення, пов'язаного із здібностями чи поведінкою працівника, або викликаного виробничою потребою підприємства, установи чи служби. Тому у разі, якщо звільнення відбулося з порушенням норм чинного законодавства, то це $є$ не тільки підставою для скасування наказу про звільнення, та ще і поновлення на роботі.

\section{Список використаних джерел:}

1. Кодекс законів про працю України, № 322-VIII. (1971). Вилучено 3 https://zakon.rada.gov.ua/laws/show/322-08.

2. Соціально-трудові відносини теорія та практика: збірник наукових знань (№ 2). (2011). Київ. 
3. Конституція України, № 254к/96-ВР. (1996). Вилучено з https://zakon.rada.gov.ua/laws/show/254\%D0\%BA/96-\%D0\%B2\%D1\%80.

4. Про затвердження Порядку погодження з Головою Ради Міністрів Автономної Республіки Крим, головами місцевих державних адміністрацій призначення та звільнення з посад керівників підприємств, установ та організацій, що належать до ссрери управління міністерств, інших центральних органів (Постанова Кабінету Міністрів України), № 818. (2013). Вилучено з https://zakon.rada.gov.ua/laws/show/818-2013-\%D0\%BF.

5. Про місцеві державні адміністрації (Закон України), № 586-XIV. (1999). Вилучено 3 https://zakon.rada.gov.ua/laws/show/586-14.

6. Про впорядкування застосування контрактної форми трудового договору (Постанова Кабінету Міністрів України), № 170. (1994). Вилучено 3 https://zakon.rada.gov.ua/laws/show/170-94-\%D0\%BF.

7. Лист Державного комітету України з питань регуляторної політики та підприємництва, № 1-222/1331. (2000). Вилучено з: https://zakon.rada.gov.ua/rada/show/v1331563-00.

8. Про практику розгляду судами трудових спорів (Постанова Пленуму Верховного Суду України), № 9. (1992). Вилучено з https://zakon.rada.gov.ua/laws/show/v0009700-92.

9. Рішення Конституційного Суду України, № 12-рп/98. (1998). Вилучено з https://zakon.rada.gov.ua/laws/show/v012p710-98.

10. Про затвердження Списку сезонних робіт і сезонних галузей (Постанова Кабінету Міністрів України), № 278. (1997). Вилучено 3 https://zakon.rada.gov.ua/laws/show/278-97-\%D0\%BF.

11. Про затвердження національних стандартів України, державних класифікаторів України, національних змін до міждержавних стандартів, внесення зміни до наказу Держспоживстандарту України від 31 березня 2004 р. № 59 та скасування нормативних документів (Наказ Державного комітету України з питань технічного регулювання та споживчої політики), ДК 002:2004 від 28.05.2004 № 97. (2004). Вилучено 3 https://zakon.rada.gov.ua/rada/show/v0097609-04.

\section{О ПОНЯТИЕ ЭКОЛОГИЧЕСКОЙ ИНФОРМАЦИИ}

Мальчик Оксана Николаевна

соискатель высшего образования юридического факультета Национального университета биоресурсов и природопользования Украины

УКРАИНА

Сейчас мир, человечество и технологии не стоят на месте, поэтому мы можем наблюдать качественные и количественные изменения относительно природы и природных ресурсов. Основной воспринимающим данных изменений является человек $и$ его здоровье, право имеет человекоизмерительное направление, а потому призвано защищать человека от злоупотреблений со стороны других людей, которые преследуют экономические выгоды. Основной проблемой является то, что национальное законодательство пока несовершенно, поскольку содержит ряд недостатков: правовой вакуум, коллизии, повторяемость норм в смежных законах. 
Вопросами экологической информации занимались различные ученые среди которых А.А. Попов, В.И. Андрейцев, И.В. Сухан, М.В. Левша, В.И. Кутузов, Н.Р. Кобецкая, М. В. Краснова, Т. Г. Ковальчук.

Актуальность исследования обусловлено тем, что сегодня наши соотечественники все чаще обращаются к понятию экологической информации при реализации экологической безопасности. Поскольку наш Основной закон прямо предусматривает право свободного доступа к информации о состоянии окружающей среды, о качестве пищевых продуктов и предметов быта, а также право на ее распространение. Такая информация никем не может быть засекречена [1].

Анализируя правовой режим экологической информации, мы видим каждый закон по-своему дает определение понятия вышеуказанному понятию, однако если проанализировать дефиниции «экологическая информация», «О состоянии окружающей природной среды», «О состоянии окружающей среды», мы можем прийти к выводу что в них заложен единый смысл.

А. Л. Дубовик, определяет экологическую информацию как любую информацию, которая: а) отражает процессы, происходящие в сфере взаимодействия природы и общества; б) необходима для целей охраны окружающей среды, то есть должна быть использована при принятии экологически значимых решений во всех сферах и видах деятельности [2].

Экологическая информация, как мы отметили широко регламентируется в национальном и международном законодательстве. Если мы возьмем специальный ЗУ «Об охране окружающей природной среды», то можем понять, что как законодатель определяет данное понятие «экологическая информация - это любая информация в письменной, аудиовизуальной, электронной или иной материальной форме о:

1) состояние окружающей природной среды или его объектов - земли, вод, недр, атмосферного воздуха, растительного и животного мира и уровне их загрязнения;

2) биологическое разнообразие и его компоненты, включая генетически видоизмененные организмы и их взаимодействие с объектами окружающей природной среды;

3) источники, фракторы, материалы, вещества, продукцию, энергию, физические фракторы (шум, вибрацию, электромагнитное излучение, радиацию), которые влияют или могут повлиять на состояние окружающей природной среды и здоровья людей;

4) угрозу возникновения и причины чрезвычайных экологических ситуаций, результатах ликвидации этих явлений, рекомендации по мерам, направленным на уменьшение их негативного воздействия на природные объекты и здоровье людей;

5) экологические прогнозы, планы и программы, мероприятия, в том числе административные, государственную экологическую политику, законодательство об охране окружающей природной среды;

6) расходы, связанные с осуществлением природоохранных мероприятий за счет фондов охраны окружающей природной среды, других источников 
финансирования, экономический анализ, проведенный в процессе принятия решений по вопросам, касающимся окружающей среды» [3]/

Ст.13 ЗУ "Об информации" отмечает, что «экологическая информация - это сведения и / или данные о:

1) состояние составляющих окружающей среды и его компоненты, включая генетически модифицированные организмы, и взаимодействие между этими элементами;

2) фракторы, которые влияют или могут влиять на составляющие окружающей среды (вещества, энергия, шум и излучение, а также деятельность или меры, включая административные, соглашения в области окружающей среды, политику, законодательство, планы и программы);

3) состояние здоровья и безопасности людей, условиях жизни людей, состоянии объектов культуры и сооружений при условии, что на них влияет или может повлиять состояние составляющих окружающей среды;

4) иные сведения и / или данные» [4].

То есть, если мы сравним общую и специальную норму, то можем выявить понятие экологической информации включает не только положения, указанные в ЗУ «Об информации», но и биологическое разнообразие, борьба с чрезвычайными экологическими ситуациями, административную и законодательную деятельность государства, финансовые вопросы по охране окружающей природной среды.

О международных источников права, то ярким является Орхусская конвенция, В которой указано, что экологическая информация "означает любую информацию в письменной, аудиовизуальной, электронной или любой иной материальной форме о:

а) состояние таких составляющих окружающей среды, как воздух и атмосфера, вода, почва, земля, ландшафт и природные объекты, биологическое разнообразие и его компоненты, включая генетически измененные организмы, и взаимодействие между этими элементами;

б) факторы, такие как вещества, энергия, шум и излучение, а также деятельность или меры, включая административные меры, соглашения в области окружающей среды, политику, законодательство, планы и программы, которые влияют или могут влиять на составляющие окружающей среды, указанные выше в подпункте а), и анализе затрат и результатов и другой экономический анализ и допущения, использованы в процессе принятия решений по вопросам, касающимся окружающей среды;

с) состоянии здоровья и безопасности людей, условиях жизни людей, состояние объектов культуры и сооружений при условии, что на них влияет или может повлиять состояние элементов окружающей среды или через эти составляющие, фракторы, деятельность или меры, упомянутые в подпункте б) [5].

То есть, мы видим по международному праву экологическая информация и ее составляющими больше похожи на трактовка, предусмотрено ЗУ «Об информации», однако по нашему мнению, является положительным что национальное специальное законодательство имеет широкий перечень охраняемых частей. На соблюдение мер данной конвенции в Украине была принята Концепция создания Общегосударственной автоматизированной 
системы "Открытое окружающей среды". Основными изменениями является то, что граждане могут рассчитывать на соблюдение их прав относительно свободного доступа к экологической информации, экологических перспектив, и применение в этих процессах интеренет и других телекомуникацийнх сетей; а также на органы и местного самоуправления и органы государственной власти покадено внедрения механизмов электронного управления, информатизации процессов по охране окружающей природной среды, рационального использования и воспроизводства природных ресурсов; [6].

Таким образом, мы исследовали что каждый имеет право на доступ к экологической информации и данное право обеспечено на национальном уровне, однако есть определенные коллизии, также мы видим, что мнение ученых в целом совпадает с нормативным видением. Понятие «экологической информации» закреплено и ряде национальных источников, а также и в международномдокументу, мы проследили, что национальное регламентирование является лучшим, поскольку содержит большее количество объектов охраны. Также выдающимся является то, что деятельность украинского правительства нацелена на расширение доступа граждан к экологической информации, прямо проявляется вих нормотворчества.

\section{Список использованных источников:}

1. Конституция Украины (Закон Украины), № 254к / 96 ВР. (1996). Изъято из http://zakon4.rada.gov.ua/laws/show/254k/96-вp.

2. Кутузов, В. И. \& Попов, А. А. (2004). Доступ к экологической инсормации: правовые аспекты. Изъято из http://www.ifap. ru/library/book121.pdf.

3. Об охране окружающей природной среды (Закон Украины), № 1264. (1991). Изъято из https://zakon.rada.gov.ua/laws/show/1264-12.

4. Об информации (Закон Украины), № 2657. (1992). Изъято из 3 https://zakon.rada.gov.ua/laws/show/2657-12

5. Орхусская конвенция, 994-015 https://zakon.rada.gov.ua/laws/show/994_015.

(1998). Изъято из

6. Концепция создания общегосударственной автоматизированной системы "Открытое окружающей среды", (825-p). Изъято из https://www.kmu.gov.ua/ua/npas/pro-shvalennyakoncepciyi-stvorennya-zagalnoderzhavnoyi-avtomatizovanoyi-sistemi-vidkrite-dovkillya 


\title{
ОКРЕМІ ПИТАННЯ ЦИВІЛЬНОЇ ПРАВОСУБ'ЄКТНОСТІ НЕПІДПРИЄМНИЦЬКИХ ТОВАРИСТВ
}

\author{
Гелецька Ірина Олександрівна \\ канд. юрид. наук, заступник директора з наукової та \\ навчально-виробничої роботи \\ Галицький коледж імені В'ячеслава Чорновола \\ УКРÄ̈HA
}

Загальнотеоретичні положення юридичної науки суб'єктом правовідносин визнають такого учасника суспільних відносин, який виступає носієм юридичних прав і обов'язків, які він реалізує завдяки наявній у нього правосуб'єктності, що є можливістю і здатністю бути суб'єктом правовідносин з усіма правовими наслідками [1]. Складовими такої властивості можуть бути правоздатність та дієздатність, що взяті разом.

Правоздатність - це абстрактна здатність суб'єкта права мати суб'єктивні права і обов'язки. Вона притаманна усім учасникам правовідносин, хоч вони не зобов'язані здійснювати усі надані їм права; це не просто набір будь-яких прав, не їх кількісне відображення, а необхідний і постійно діючий стан [1].

Юридична особа хоча і $є$ реальним учасником правовідносин, але разом 3 тим $€$ штучною конструкцією, що виникла за волею людини, а відтак і дієздатність її пов'язується з іншим юридичним фактом - державна реєстрація, тобто із сукупністю дій, які разом формують фактичний склад.

У зв'язку з цим, зважаючи на безпосередній взаємозв'язок юридичних фактів (зовнішній вираз) та правосуб'єктність (внутрішня властивість учасника правовідносин), можемо зробити висновок, що для участі у цивільно-правових відносинах непідприємницьке товариство має вчинити юридичну дію. Однак для цього воно повинне мати першооснову і здатність до їі реалізації, тобто правоздатність (абстрактну можливість) і дієздатність (реальну можливість).

Ст. 85 Цивільного кодексу України (далі - ЦК України) [2] непідприємницьким називає таке товариство, яке не має за основну мету своєї діяльності одержання прибутку для його наступного розподілу між учасниками. Прикладами таких товариств можуть бути об'єднання громадян, благодійні чи релігійні організації, політичні партії, споживчі кооперативи тощо. Незважаючи на те, що ЦК України у ст. 85 наголошує на неможливості отримання прибутку в ході своєї діяльності непідприємницькими товариствами, водночас ст. 86 цього ж законодавчого акту дозволяє останнім поряд із основною діяльністю здійснювати і підприємницьку, якщо інше не передбачено законом і якщо ця діяльність відповідає меті, для якої вони були створені, та сприяє їі досягненню.

У противагу підприємницьким товариствам, непідприємницькі не є професійними учасниками майнових відносин. Такі товариства створюються для досягнення визначеної мети, а тому мають наділятися спеціальною правоздатністю, оскільки можуть здійснювати виключно дії, що спрямовані на досягнення поставленої мети: наукової, освітньої, культурної тощо. За 
положеннями законодавства виключно для її досягнення непідприємницькі товариства можуть займатися і підприємницькою діяльністю.

На перший погляд, для сучасності така обставина $€$ вкрай важливою, оскільки надає можливість створювати матеріальну базу для забезпечення основної статутної діяльності та реалізації власних статутних цілей. Але поряд із цим залишає без відповідей окремі питання такої діяльності.

Регулюючи правовий статус непідприємницьких товариств, законодавець за допомогою двох критеріїв встановлює межі правомірності здійснення такої діяльності: підприємницька діяльність повинна відповідати цілям діяльності і сприяти їх досягненню.

Як наголошує К.В. Кацюба, [3] у законодавстві не розкривається поняття «відповідність цілям діяльності», а також не визначено критерії оцінки відповідності статутним цілям здійснюваної підприємницької діяльності. У результаті це призводить до того, що на практиці відповідним цілям діяльності непідприємницького товариства можливо вважати будь-яку підприємницьку діяльність, що не суперечить законодавству.

Аналізуючи та порівнюючи спеціальне законодавство у сорері непідприємницьких юридичних осіб з ЦК України, можемо зробити висновок, що надання права непідприємницьким юридичним особам займатися підприємницькою діяльністю не вирішує питання, яким чином це має відбуватися.

Здійснювати підприємницьку діяльність можливо у різних формах. Це може бути як виготовлення чи продаж товарів, виконання робіт, надання послуг, так і розміщення тимчасово вільних фінансових активів у кредитних (банківських) установах або цінних паперах, передача майна у тимчасове користування тощо. Цілком зрозуміло, що перша форма здійснення підприємницької діяльності передбачає більш активну підприємницьку поведінку учасника цивільного обороту, аніж інша, що за своєю природою не $\epsilon$ суто підприємницькою і дозволяє непідприємницьким товариствам зберегти непідприємницький характер власної діяльності.

Якщо ж у непідприємницького товариства буде виникати потреба у додатковому матеріальному забезпеченні, у збільшенні власних фінансових активів і ним буде розглядатися можливість, наприклад створення власного виробництва, то як варіант, воно може створити нову підприємницьку юридичну особу, яка і буде провадити вказану діяльність, сплачувати податки, а отримані прибутки передавати для досягнення мети засновника. У такому випадку, на нашу думку, не буде необхідності з'ясовувати підприємницьку діяльність непідприємницького товариства або встановлювати її межі. Головне, аби непідприємницьке товариство не почало активно займатися підприємницькою (бізнесовою) діяльністю, отримувати внаслідок цього значні прибутки і здійснювати їх оподаткування за правилами для непідприємницьких товариств. Таке зловживання також не варто виключати.

Загалом, розподіл юридичних осіб на підприємницькі юридичні особи і непідприємницькі властивий виключно цивільному обороту 3 метою розмежування непідприємницьких товариств і господарюючих суб'єктів. I правова сутність непідприємницького товариства не допускає досить активної участі останніх в господарському обороті чи в іншій діяльності, що не 
відповідає меті його створення. Тому надання права непідприємницьким товариствам займатися підприємницькою діяльністю, на наш погляд, $€$ спірним. Ми розуміємо, що в сучасних умовах непідприємницьке товариство змушене самостійно дбати про своє матеріальне забезпечення, але поряд 3 тим - законодавчі вимоги, які встановлені для здійснення підприємницької діяльності, через свою невизначеність не отримали однакового застосування на практиці, а отже, непідприємницьким товариствам дотримуватися їх при здійсненні саме підприємницької діяльності досить складно.

Неможливо оминути увагою і питання майнової відповідальності непідприємницького товариства при здійсненні ним підприємницької діяльності, адже положення ст. 96 ЦК України в контексті самостійної майнової відповідальності юридичної особи за своїми зобов'язаннями усім належним їй майном поширюються і на непідприємницьке товариство, яке виявить бажання здійснювати підприємницьку діяльність, оскільки останнє є однією 3 організаційно-правових форм юридичної особи. Майнова відповідальність непідприємницьких товариств полягає у тому, що їх засновники (учасники) не мають майнових прав на майно створюваних організацій. Виходячи із цієї тези, можна стверджувати, що непідприємницьке товариство не зможе належним чином відповідати у випадку невиконання чи неналежного виконання зобов'язань, що будуть виникати при здійсненні останнім підприємницької діяльності.

Разом з тим і прибуток, який отримує підприємницьке і непідприємницьке товариство при здійсненні підприємницької діяльності, розподіляється по різному: для перших - між його учасниками, а інших - спрямовується на досягнення мети, задля якої його було створено. Зумовлено це тим, що при створенні підприємницького товариства його засновники (учасники) роблять певні внески для формування статутного (складеного) капіталу останнього, у зв'язку з чим і переслідують мету отримання прибутку; для непідприємницького ж має місце зовсім інша мета створення і діяльності. Відсутність достатнього стартового капіталу, на наш погляд, є ще однією 3 підстав для окреслення законодавчих меж здійснення непідприємницькими товариствами підприємницької діяльності.

Які б аргументи ми не наводили, все-таки, непідприємницькі товариства беруть досить активну участь у цивільному обороті, а відтак необхідно віднайти можливість забезпечити інтереси як їх самих, так і їхніх кредиторів. Варто погодитися з позицією К.В. Кацюби [3], що вирішити вказану проблему можливо через встановлення заборони прямої участі непідприємницьких товариств у підприємницькій діяльності або звести таку участь до мінімальних розмірів, оскільки будь-яка підприємницька діяльність товариства має бути другорядна, вторинна, навіть непостійна.

На нашу думку, доцільно було б законодавчо встановити межі такої діяльності, окресливши ії, наприклад, лише можливістю інвестування тимчасово вільних коштів у фінансові інституції, передачею майна, що тимчасово не використовується у найм або наданням окремих послуг на платних засадах тощо.

Висновок. Незважаючи на те, що законодавець надав право непідприємницьким товариствам здійснювати підприємницьку діяльність, 
дієвого механізму реалізації цього права ним не вироблено. Підприємницька діяльність непідприємницьких товариств має свою специфіку і не завжди відповідає аналогічній діяльності, що здійснюється суб'єктами господарювання.

\title{
Список використаних джерел:
}

1. Цвік, М. В., Петришин, О. В. \& Авраменко, Л. В. (2011). Загальна теорія держави і права. М. В. Цвік (ред.). Харків: Право.

2. Цивільний кодекс України (Закон України), № 435-IV (2019). Вилучено 3 https://zakon.rada.gov.ua/laws/show/435-15\#n2.

3. Кацюба, К. В. (2014). Цивільна дієздатність непідприємницьких товариств. Теорія і практика правознавства, $2(6), \quad 2-6 . \quad$ Вилучено 3 http://tlaw.nlu.edu.ua/article/download/63299/58709\&usg=AOvVaw3mO4Fc7LfLRnrxgS_JIXKk.

\section{ОСОБЛИВОСТІ ПРАВОВОГО СТАТУСУ ТВАРИН В УКРАЇНІ}

\author{
Лопацька Юлія Вікторівна \\ здобувач вищої освіти юридичного факультету IV курсу \\ Київський національний університет імені Тараса Шевченка \\ УКРӒ̈HA
}

Проблема правового статусу тварин є одним з найбільш актуальних і дискусійних питань українського права. Характерною рисою цієї правової категорії $€$ її двозначність. 3 одного боку, людина все ще експлуатує тварин в різних сферах своєї життєдіяльності, що часто обумовлені навіть об'єктивними потребами самої людини. 3 іншого боку, сучасне суспільство визнає необхідність визнання жорстокості до тварин - в процесі цієї експлуатації чи поза нею - проявом антигуманності та несправедливості. Про це, зокрема, зазначається у Всесвітній Хартії природи: «будь-яка форма життя є унікальною та заслуговує на повагу, якою б не була її корисність для людини, і для визнання цієї невід'ємної цінності інших живих істот людина повинна керуватися моральним кодексом поведінки» [1]. Результатом такої двозначності став компроміс у вигляді особливого правового становища тварини в українському законодавстві, при якому вона не є суб'єктом права, однак користується особливим захистом з боку закону, що обумовлені її природою як живої істоти.

Статус тварини визначається, передусім, в ч. 1 ст. 80 Цивільного кодексу України, відповідно до якої тварини є особливим об'єктом цивільних прав. На них поширюється правовий режим речі, крім випадків, встановлених законом [2]. Це положення свого часу було своєрідною цивілістичною новелою, оскільки Цивільний кодекс УРСР 1963 р. ніяк не виділяв статус тварини узагалі. Варто зазначити, що хоч законодавець і вважає, що на тварин поширюється правовий режим речі, що перш за все розуміє під собою здатність тварин бути предметом цивільного обороту (тобто бути предметом договорів купівлі- 
продажу, дарування та інших), він не прирівнює тварину до всіх інших об'єктів матеріального світу, оскільки в статті робиться акцент саме на тому, що це особливий об'єкт, а не річ як така. Особливість тварини як об'єкту цивільного права визначається в цій же статті, але в ч. 2, де вказується, що правила поводження з тваринами встановлюються законом.

Головним законом, що встановлює правила поводження з тваринами в Україні, $€$ Закон України «Про захист тварин від жорстокого поводження». Відповідно до ст. 4 цього Закону поводження з тваринами ґрунтується на таких принципах: жорстоке поводження з тваринами $€$ несумісним з вимогами моральності та гуманності, спричиняє моральну шкоду людині; забезпечення умов життя тварин, які відповідають їх біологічним, видовим та індивідуальним особливостям; право власності та інші речові права на тварин у разі жорстокого поводження з ними можуть бути припинені відповідно до цього Закону; заборона жорстоких методів умертвіння тварин; відповідальність за жорстоке поводження з тваринами; утримання і поводження 3 домашніми тваринами без мети заподіяння шкоди як оточуючим, так і самій тварині [3]. Власне, з вищевказаних положень Закону можна зробити висновок, що ключовим моментом, який повинен враховуватися при будь-якій взаємодії людини з твариною - це неможливість жорстокого ставлення до тварини. В цьому і полягає своєрідний компроміс, який являє собою статус тварини в українському праві: при тому, що людина все ще може використовувати тварин в своїй діяльності, вона при цьому не може допускати жорстокості. У зв'язку з цим виникає необхідність визначення самого терміну «жорстоке поводження 3 твариною». Таке визначення міститься в ст. 1 Закону України «Про захист тварин від жорстокого поводження», відповідно до якої жорстоке поводження з тваринами - це знущання над тваринами, у тому числі безпритульними, що спричинило мучення, завдало їм фізичного страждання, тілесні ушкодження, каліцтво або призвело до загибелі, нацьковування тварин одна на одну та на інших тварин, вчинене з хуліганських чи корисливих мотивів, залишення домашніх та сільськогосподарських тварин напризволяще, у тому числі порушення правил утримання тварин. Не дивлячись на достатньо чіткий перелік діянь, що підпадають під поняття жорстокого поводження із твариною, щодо визначеності цього терміну в суспільстві досі тривають жваві дискусії. Особливо гостро постає питання щодо способу умертвіння тварини. Річ у тім, що закон містить вимогу умертвляти тварин виключно тими методами, що виключають передсмертні страждання тварин. У зв'язку з цим існують полярні думки щодо того, наскільки гуманно чи жорстоко позбавляти тварину способами, які використовують для забою сільськогосподарських тварин. Це одне з найбільш складних питань у сфері захисту тварин від жорстокого поводження.

Варто зазначити, що згідно із ст. 35 Закону України «Про захист тварин від жорстокого поводження» за порушення вимог цього ж Закону винні особи можуть нести кримінальну, адміністративну та цивільну правову відповідальність. Кримінальна відповідальність передбачена передусім статтею 299 Кримінального кодексу України, а адміністративна - статтею 89 Кодексу України про правопорушення. Відповідно до ч. 1 ст. 299 жорстоке поводження 3 тваринами, що відносяться до хребетних, у тому числі 
безпритульними тваринами, що вчинене умисно та призвело до каліцтва чи загибелі тварини, а також нацьковування тварин одна на одну чи інших тварин, вчинене з хуліганських чи корисливих мотивів, публічні заклики до вчинення діянь, які мають ознаки жорстокого поводження з тваринами, а також поширення матеріалів із закликами до вчинення таких дій караються арештом на строк до шести місяців або обмеженням волі на строк до трьох років [4]. Можливий також кваліфікований склад цього злочину, передбачений в частинах 2 і 3 ст. 299, - наприклад, його вчинення на очах у малолітнього чи неповнолітнього, або щодо двох або більше тварин, або повторно та інші. Згідно з ч. 1 ст. 89 Кодексу України про адміністративні правопорушення жорстоке поводження з тваринами - знущання над тваринами, завдання побоїв або вчинення інших насильницьких дій, що завдали тварині фізичного болю, страждань і не спричинили тілесних ушкоджень, каліцтва чи загибелі, залишення тварин напризволяще, у тому числі порушення правил утримання тварин, тягнуть за собою накладення штрафру від двохсот до трьохсот неоподатковуваних мінімумів доходів громадян з конфіскацією тварини, якщо перебування тварини у власника становить загрозу для її життя або здоров'я [5]. Як і в Кримінальному кодексі, в Кодексі про адміністративні правопорушення вказано на обтяжуючі обставини цього правопорушення. Аналізуючи ці норми, можна дійти висновку, що кримінальну відповідальність особа буде нести, якщо жорстоке поводження із тваринами спричинило тілесні ушкодження, каліцтво або загибель тварини; якщо ж ні - то особа притягується до адміністративної відповідальності.

ще однією особливістю правового становища тварин $є$ те, що не у всіх воно $€$ однаковим. В Законі України «Про захист тварин від жорстокого поводження» згадуються наступні види тварин: дикі, домашні, сільськогосподарські, а також безпритульні, хутрові, зоопаркові, лабораторні, циркові, мисливські та інші. Така класифікація тварин допомагає ефективніше регулювати їх статус та охорону як особливого об'єкта правового регулювання. Так, наприклад, статус диких тварини додатково регулюється нормами Законів України «Про тваринний світ», «Про охорону навколишнього середовища» та окремі види, що занесені до Червоної книги України - Закону України «Про Червону книгу України». Окремої уваги заслуговують тварини, утримання яких Цивільним кодексом визначено як джерело підвищеної небезпеки. Відповідно до ч. 1 ст. 1187 Цивільного кодексу України такими тваринами є дикі звірі (в Кодексі цього не зазначено, однак з норми логічно випливає, що маються на увазі звірі, що перебувають в напіввільних умовах або в неволі), а також службові та мисливські собаки. Для самих тварин такий статус не створює жодного погіршення їх правового становища, однак на їх господаря накладається обов'язок вжити всіх необхідних заходів для уникнення ситуацій, в яких ці тварини завдали би шкоду іншим особам; а у разі виникнення таких ситуацій відшкодовувати шкоду в порядку, визначеному законом.

Підсумовуючи, можна зробити висновок, що тварина не є суб'єктом права, і в будь-яких правовідносинах вона так чи інакше буде об'єктом. Разом з тим, ії статус значно відрізняється від інших об'єктів правовідносин, оскільки законом встановлені певні правила поводження з тваринами, що $\epsilon$ обов'язковими для дотримання. Основним таким правилом, відповідно до 
українського законодавства, $є$ заборона жорстокого ставлення до тварини, а саме - завдання їй фрізичного болю, що спричиняє великі страждання. У випадку порушення вищезгаданих правил до господаря тварин можуть бути застосовані санкції - зокрема, він може бути притягнутий до кримінальної відповідальності. Не дивлячись на ряд існуючих проблем у сфері захисту тварин від жорстокого поводження, українському законодавству в цілому вдалося досягнути компромісу між потребами людини та природніми потребами тварини, щоб забезпечити їх гармонійне співіснування в сучасному світі.

\title{
Список використаних джерел:
}

1. Всесвітня Хартія природи (міжнародний документ ООН від 01.01.1982). (2019). Вилучено 3 https://zakon.rada.gov.ua/laws/show/995_453.

2. Цивільний кодекс України (Закон України). № 435-IV. (2019). Вилучено 3 https://zakon.rada.gov.ua/laws/show/435-15.

3. Про захист тварин від жорстокого поводження (Закон України). № 3447-IV. (2019). Вилучено 3 https://zakon.rada.gov.ua/laws/show/3447-15.

4. Кримінальний кодекс України (Закон України). № 2341-III. (2019). Вилучено 3 https://zakon.rada.gov.ua/laws/show/2341-14.

5. Кодекс України про адміністративні правопорушення (Закон України). № 8073-Х. (2019). Вилучено 3 https://zakon.rada.gov.ua/laws/show/80731-10.

\section{ПАПІЛЯРНІ ЛІНІї: ОСНОВНИЙ КЛюч дО РОЗКРИТТЯ ЗЛОчИНІВ}

\begin{abstract}
Махно Катерина Олексіївна
здобувач вищої освіти юридичного фракультету Дніпровський національний університет імені Олеся Гончара

Науковий керівник: Сачко Олександр Васильович канд. юрид. наук, доцент, доцент кафедри адміністративного і кримінального права Дніпровський національний університет імені Олеся Гончара
\end{abstract} УКРАЇ̈A

Як за часів найпростіших криміналістичних досліджень біологічних слідів людини, так i за сучасних вдосконалених біометричних пристроїв ідентифрікації, відбитки пальців рук були основним ключем для правоохоронних органів до розкриття злочинів. Сьогодні, комп'ютеризовані бази даних дозволяють порівняти тисячі, навіть мільйони відбитків пальців за хвилини.

Відбитки пальців - це крихітні хребти, бороздки та візерунки на кінчику кожного пальця. Ці лінії навіть унікальніші за ДНК, оскільки немає двох людей, які мають однакові відбитки пальців - вони абсолютно унікальні. $€$ лише один з 64 мільярдів шансів, що відбиток однієї людини збігається з відбитками іншої. 
Папілярні лінії або візерунки (саме їх ми називаємо відбитками) $€$ також на долонях та стопі, на пальцях не тільки рук, але й ніг. Ці лінії зустрічаються на долонях та стопах усіх приматів (людей, горил, мавп). Папілярні лінії розвиваються ще в утробі матері і залишаються незмінними протягом усього життя. Люди ростуть і збільшуються в розмірах, але візерунки на пальцях, які сформувалися приблизно на 17 тижні ембріонального розвитку, на відміну від інших частин нашого тіла, що змінюються, є постійними.

Структурність та стійкість відбитків дозволяє класифікувати їх. Той фракт, що відбитки пальців можна систематично сортувати та каталогізувати, і був головною причиною їх широкого прийняття та застосування правоохоронними органами. Однак, необхідно пам'ятати, що будь-яка класифрікація, з огляду на унікальність відбитків пальців, може проводитися лише за загальними критеріями, виключаючи індивідуалізуючі елементи.

Першим науковцем, який намагався систематизувати відбитки пальців, був доктор Ян Евангеліста Пуркинє, чеський лікар і один із "гігантів" в історії фізіології. У 1823 році він на своїх лекціях розповідав про папілярні лінії у людей і приматів та наводив свій приклад класифікації, який складався 3 дев'яти різних основних моделей візерунка.

У 1880 році доктор Генрі Фулдс, шотландець, який працював у лікарні в Токіо, дослідив відбитки пальців, помітивши їх на стародавніх глиняних виробах. Згодом, надбання своїх досліджень Фулдс навіть використав для розкриття крадіжки пляшки алкоголю 3 крамниці. Він опублікував свої дослідження щодо використання та класифікації відбитків пальців у листі до наукового журналу «Nature». Публікація листа Фулдса викликала швидку негативну відповідь від Вільяма Гершеля, головного адміністратора Бенгальського бюро уряду Британії в Індії, який стверджував, що саме він, а не Фулдс, винайшов техніку ідентифікації людини за відбитками пальців.

Сьогодні всі відбитки пальців поділяються на три основні типи: петлі, дуги та завитки, з додатковою розбивкою кожного типу на різновиди, відповідно до особливостей будови візерунку [1].

Завиткові візерунки зустрічаються рідше за інші типи (близько 11\%). Однак вони відрізняються найбільш складною і різноманітною будовою. Завиткові візерунки поділяються на кілька різновидів: а) прості; б) спіралеподібні; в) петлі-клубки; г) атипові візерунки зі складною будовою центральної частини.

Частота зустріваності петльових візерунків - близько 35\%. Петльові візерунки поділяються на кілька різновидів: а) прості; б) вигнуті; в) замкнуті; г) половинчасті.

Дугові візерунки є найбільш поширеними (близько 54\%). Вони влаштовані значно простіше інших, тому що мають один, а не три потоки папілярних ліній. Дугові візерунки поділяються на кілька різновидів: а) прості; б) пірамідальні; в) шатрові; г) шаруваті; д) з невизначеною будовою центральної частини; е) згладжені.

Стійкість залишеного відбитку визначити майже неможливо, оскільки вона залежить від того, на якому матеріалі чи речовині, вони були залишені та від умов навколишнього середовища. Так, відбитки на пластику будуть залишатися там до тих пір, поки сам матеріал залишиться структурно 
недоторканим. А от "термін придатності" слідів, залишених на пилу є досить коротким. Неявні ж сліди, під захистом відповідних умов, можуть залишатися роками.

Як і будь-який інший вид доказів, відбитки пальців можуть бути дуже корисними, як для криміналіста зокрема, так і для усього ходу слідчих дій загалом: вони можуть допомогти у скасуванні підозри щодо невинуватих фігурантів слідчих дій та у притягненні до відповідальності винуватих [2].

\title{
Список використаних джерел:
}

1. Тараскаев, С. А. (2009). Классификация папиллярных узоров. Бизнес в законе, (1), 205-207. Вилучено 3 https://cyberleninka.ru/article/v/o-klassifikatsii-papillyarnyh-uzorov-na-paltsah-stopcheloveka.

2. Лукашевич, Г. В. (2016). Докази та доказування в кримінально-процесуальному та криміналістичному вимірі. Держава та регіони, (1), 74-79. Вилучено 3 http://www.law.stateandregions.zp.ua/archive/1_2016/16.pdf.

\section{ПЕРСПЕКТИВИ ЗАПРОВАДЖЕННЯ ЕЛЕКТРОННОГО HOTAPIATУ В УКРАÏHI}

\author{
Гердова Кристина Олександрівна \\ Дніпровський національний університет імені Олеся Гончара \\ Науковий керівник: Щербина $€$. М. \\ канд. ю. наук, доцент \\ Дніпровський національний університет імені Олеся Гончара \\ УКРАЇHA
}

Останні декілька років спостерігається процес активного розвитку інфрормаційного суспільства. Він включає в себе запровадження електронних послуг у всі сфери нашого життя, використання електронного цифрового підпису, перехід від паперового документообігу до електронного. Така тенденція покликана забезпечити прискорення процедури ділового обігу, а також покращення та спрощення діяльності державних органів влади, підприємств, установ і організацій різних фрорм власності.

Нотаріуси - одні із перших представників юридичної профресії, які продемонстрували свою впевненість і готовність до роботи з цифровими технологіями, освоюючи електронні реєстри. I на сьогоднішній день, постало питання запровадження електронного нотаріату в Україні.

Тематика використання інформаційних технологій у нотаріальній діяльності та функціонування е-нотаріату безпосередньо в Україні $\epsilon$ недостатньо дослідженою. Даним питанням присвячені праці Кузьмінської О. Ю., Дєнєжкіної Ю. В., Орзіха Ю. Г. та інших науковців.

Наразі нотаріуси України під час здійснення своєї професійної діяльності користуються великою кількістю реєстрів, а саме: Єдиний реєстр нотаріусів, 
Єдиний реєстр спеціальних бланків нотаріальних документів, Державний реєстр обтяжень рухомого майна, Спадковий реєстр, Єдиний реєстр довіреностей, Державний реєстр речових прав на нерухоме майно, Державний реєстр актів цивільного стану громадян, Єдиний державний реєстр юридичних осіб, фізичних-осіб підприємців та громадських формувань. Робота з такою великою кількістю реєтрів вимагає від нотаріуса багато часу і зусиль. До того ж, достовірність даних, які містяться в них не завжди відповідає дійсності. До прикладу можна взяти «нотаріальний реєстр» довіреностей. Нотаріуси вносять до цього реєстру відомості про посвідчені ними довіреності та перевіряють в ньому чинність інших довіреностей. Однак, приміром, консульські установи, що також вчиняють такі нотаріальні дії за кордоном, не мають доступу та не користуються цим реєстром. Вони не перебувають під юрисдикцією Міністерства юстиції, не вносять жодної інфрормації про посвідчені ними довіреності та не мають зв'язку з нотаріальною системою України. Хоча реалізацію прав громадян України вони забезпечують. Таким чином, реєстр довіреностей не є повним [1].

Тому 3 метою оптимізації та спрощення нотаріальної діяльності Нотаріальною палатою України в 2017 році був розроблений та запропонований проект Концепції розвитку та реформування нотаріату в Україні. Основним завданням Концепції є створення єдиного Електронного реєстру вчинення нотаріальних дій; Електронної нотаріальної інформаційної системи «E-Notar», у яку ввійдуть нотаріальні реєстри та реєстри, що можуть наповнюватися іншими користувачами, окрім нотаріусів; електронного цифрового нотаріального архіву й звітності. Також е-нотаріат включає в себе відповідне автоматизоване робоче місце нотаріуса (із реєстром, архівом, звітністю), електронний портал клієнтів із історією вчинення нотаріальних актів, автоматизацію оплати нотаріальних дій, цифрову ідентифікацію особи, дистанційний нотаріат тощо [2].

Узагалі технологія електронного нотаріату вже діє в ряді таких країн, як Естонія, Грузія, Республіка Казахстан, Франція та інші. Наприклад, у Франції діє Єдина електронна нотаріальна мережа. Вона надає змогу нотаріусам обмінюватися даними реєстрів між собою та з третіми особами. Кожен нотаріус має ідентифікаційну картку «Carta Real» з конфіденційним кодом, яка надає доступ не тільки до електронної мережі в межах Франції, але й до мережі європейської бази даних про заповіти та документи європейського нотаріату [1].

На думку автора, основними перевагами запровадження електронного нотаріату в Україні $є$ :

1. створення єдиного Електронного реєстру вчинення нотаріальних дій сприятиме полегшенню роботи нотаріусів, економії їх часу, адже всі документи будуть зібрані в одному реєстрі, що дасть змогу нотаріусам швидше знаходити необхідні;

2. запровадження електронного нотаріату надасть можливість поступово відмовитися від паперових архівів та повністю перейти на електронне документування; 
3. е-нотаріат створює умови для електронного документообігу між нотаріусами і третіми сторонами та для нотаріального посвідчення правочинів за допомогою електронних засобів зв'язку.

Проте $є$ певні недоліки запровадження даної новації і в першу чергу, це ризик кібератак. Для забезпечення ефективного та безпечного функціонування електронного нотаріату необхідно створити досконалу систему захисту фрайлів та їх зберігання. Адже коли всі дані акумульовані в одному реєстрі, важливо виключити будь-який ризик його злому, знищення архіву нотаріуса або викрадення конфіденційної інфрормації.

Прикладом такого правопорушення $є$ кібернетична атака в Україні, яка відбулася в 2017 році, а саме вірус «Реty. А». Ця кібератака спровокувала зупинення роботи систем електронного документообігу та прийняття електронної звітності контролюючими органами. Також правопорушники намагалися зламати особисті кабінети нотаріусів у Державних реєстрах та від імені нотаріусів переписували майно та знімали обтяження з транспортних засобів [3].

Отже, безумовно, електронний нотаріат - це система, яка створить нові можливості для оптимізації діяльності нотаріусів, приведе до більшої структурованості та оперативності в їхній роботі. Так, окремі європейські країни вже запровадили е-нотаріат, проте в Україні це повинно відбуватися 3 урахуванням нашої правової системи, економічного рівня та можливостей в цілому.

\section{Список використаних джерел:}

1. Кузьмінська, О. Ю. (2018). Електронний нотаріат. Грані права: XXI століття: матеріали Всеукраїнської науково-практичної конфференції (м. Одеса, 19 травня 2018 р.), 350-352.

2. Нотаріальна палата України. (2017). Звіт про роботу Нотаріальної палати України 2017 p. Вилучено 3 http://npu.org.ua/wp-content/uploads/2018/02/Zvit_2017.pdf

3. Грабчук, І. Л. (2018). Організація захисту облікової інформації в умовах гібридної війни. Проблеми теорії та методології бухгалтерського обліку, контролю і аналіз, 3 (41), 2024. 


\section{ПЕРСПЕКТИВИ ПЕРЕХОДУ ЦИВІЛЬНОГО СУДОЧИНСТВА В УКРАЇНІ У ПРИВАТНИЙ СЕКТОР}

Махно Катерина Олексіївна

здобувач вищої освіти юридичного фракультету Дніпровський національний університет імені Олеся Гончара

Науковий керівник: Резникова Марія Олександрівна канд. фрілос. наук, доцент, доцент кафедри цивільного, трудового та господарського права Дніпровський національний університет імені Олеся Гончара

УКРӒ̈HA

Критичний аналіз та порівняння східних та західних, переважно європейських, систем цивільного правосуддя викривають прямо протилежні реформаційні настрої держав.

3 одного боку, ми маємо держави в яких можна спостерігати більш-менш очевидні наміри реформ та зусилля, прямо спрямовані на перегляд сьогоднішньої системи правосуддя або, простіше кажучи, на абсолютно нову побудову чи відновлення існуючої національної судової адміністрації та судових установ. Як результат, суди в таких країнах незалежні та потужні органи державної влади, відбувається диверсифікація їх юрисдикцій та компетенцій, судові процеси стають ефективнішими [1]. Конкретними наслідками таких реформ стають збагачення традиційних юрисдикцій (такими називають цивільну та кримінальну галузь) сімейними, трудовими, адміністративними та / або конституційними юрисдикціями, так звані, суди справедливості та суди, в які призначають науковців, практиків (адвокатів, юрисконсультів тощо), юридично кваліфікованих та чесних суддів.

Незважаючи на практичний досвід вищеописаних країн, який можна i потрібно було б запозичити, з іншого боку, існують і такі країни, реформування судової системи яких пішло у зворотному напрямку і спричинило ії деградацію. Зазвичай, причиною цьому є тотальне «скорочення» в усьому, що стосується правосуддя та судових установ, приховане під популістичними гаслами про раціоналізацію, нормування, економізацію та спрощення судових процедур. Подібні тенденції спричиняють руйнування системи судочинства загалом та цивільного судочинства зокрема.

Неефективність судової системи таких країн, породжена деградацією, та її неспроможність захищати права населення, спричиняє неконтрольоване виникнення та розвиток сумнівного, інколи навіть злочинного, приватного «правосуддя» (наприклад, народна «судова влада», бандитська «судова влада» тощо). Звісно, зазвичай, держава намагається заволодіти контролем над ним: або шляхом надмірної централізації судової влади, або шляхом легалізації (націоналізації) певних форм так званого альтернативного вирішення спорів, пропонуючи «краще правосуддя» завдяки штучному розширенню судової системи.

В країнах 3 ефрективно працюючою судовою владою навпаки спостерігається тенденція до переходу у приватний сектор частини колишніх 
суто державних органів цивільного судочинства, оскільки найчастіше державна судова система сильно страждає від перевантаження справами.

Саме перевантаження справами, на думку більшості державних чиновників, реформаторів, співробітників міністерств юстиції та вищих суддів, відповідальних за управління судовою системою є тим «головним злом», що заважає швидкому та якісному розгляду справ, особливо в цивільному судочинстві.

Не варто забувати і про заміну чи доповнення судової системи держави та судових процедур застосуванням так званого альтернативного вирішення спорів, наприклад, через нестандартні або позасудові інструменти вирішення конфліктів, такі як примирення, переговори, посередництво та арбітраж, які існують вже декілька десятиліть у Європі і вплив яких продовжує зростати, що, безумовно, є важливим, хоча і не єдиним показником «приватизації» сектору правосуддя.

Надмірна тривалість судового провадження та виконання судових рішень в Україні, які спричинені, перш за все, недостатньою кількістю суддів, - це ключові проблеми здійснення правосуддя, які свідчать про неефективність судової системи. На жаль, це особливо відчувається під час розгляду та вирішення саме цивільних справ - деякі провадження щодо яких тривають роками. Не рятує ситуацію і передбачена законодавством можливість утворення та діяльності третейських судів.

Під великим сумнівом і ефективність застосування позасудових інструментів вирішення спорів, оскільки проект Закону України «Про медіацію» був відхилений Верховною Радою України, а, передбачене чинним Цивільним процесуальним кодексом України, врегулювання спору за участю судді, хоча і проводиться до початку розгляду справи по суті, однак все ж таки відбувається за участі саме державного органу - в особі судді.

Вважаємо, що задля ефективного захисту порушених, невизнаних або оспорюваних прав, свобод чи інтересів фрізичних осіб, прав та інтересів юридичних осіб, інтересів держави, судова система України потребує кардинальних змін, шляхом розвантаження існуючих судів - законодавче закріплення та стимулювання використання позасудових інструментів вирішення спорів, створення форм альтернативного вирішення спорів. Це має стати головним імпульсом реформи, двигуном усіх нових законодавчих реформ у сфері цивільного процесуального права.

\section{Список використаних джерел:}

1. Гуцалюк, О. В. (2015). Зарубіжний досвід реформування судової влади. Науковий вісник Ужгородського національного університету, (33-2), 157-161. Вилучено з http://www.visnykjuris.uzhnu.uz.ua/file/No.33-2/part_1/41.pdf.

2. Бондаренко-Зелінська, Н. Л. (2018). Врегулювання спору за участю судді: проблеми та перспективи застосування. Університетські наукові записки, (67-68), 62-70. Вилучено з http://univer.km.ua/visnyk/1786.pdf. 


\title{
ПЕРСПЕКТИВИ ТА ПРОБЛЕМИ КОНЦЕПЦІЇ ЕЛЕКТРОННОГО КРИМІНАЛЬНОГО ПРОВАДЖЕННЯ В УКРАЇНІ
}

\author{
Абражевич Дар'я Артемівна \\ здобувач вищої освіти юридичного фракультету \\ Національний авіаційний університет \\ УКРАÏHA
}

В Генеральній прокуратурі України розробляється концепція електронного кримінального провадження. До цього процесу відноситься створення Єдиного реєстру досудових розслідувань; надалі перехід до того, щоб матеріали провадження надходили електронною поштою за допомогою електронного документообігу, що пришвидшить процес розгляду справи.

У сорері кримінального правосуддя, зазвичай, в останню чергу запроваджуються зміни, які стосуються оцифрування кримінального процесу.

Електронне кримінальне провадження - це електронна система, що оцифровує фізичну документацію, яка дозволяє обмінюватись фрайлами в кримінальних справах. Вона має спростити роботу усіх учасників кримінальних розслідувань, особливо поліції, прокурорів та суддів [1].

Створення електронного кримінального провадження дозволить швидше обробляти великий обсяг даних про злочини, застосовуючи під час цього норми законодавства, ніж це робила б людина власноруч. Також це унеможливить невірну кваліфрікацію справи, та буде неможливо фальсифікувати справи та порушувати законодавство.

Можна буде швидше здійснювати перевірку правоохоронних органів щодо розслідування кримінальних правопорушень.

До подолання проблем впровадження електронного кримінального провадження в Україні долучається багато правничих експертів та науковців, а також міжнародних експертів [2]. Наприклад, Кристина Арашунян (старший викладач відділу підготовки прокурорів з процесуального керівництва), звертає увагу на те, що запровадження системи електронного кримінального провадження запроваджується на всіх рівнях держави. В Академії прокуратури України здійснюється навчання по роботі з Єдиним реєстром досудових розслідувань. Також розроблена та впроваджена навчальна дисципліна, яку проходять кандидати на посади прокурорів. Заняття проводяться в комп'ютерних аудиторіях, де слухачі отримують навички 3 користування електронною системою.

Але наразі існує багато проблем щодо запровадження електронного кримінального провадження, серед них:

1) Немає єдиного визначення електронного кримінального провадження, та його структурних елементів.

2) Відсутнє нормативне врегулювання і запровадження державного фрінансування цієї системи.

3) Необхідно створити та врегулювати режим доступу до електронного кримінального провадження. 
4) Розробити його систему так, щоб воно було ефективним та дієвим не лише для правоохоронних органів, але й для захисників (щоб вони не мали проблем щодо доступу та співпраці).

5) Унеможливити підробку електронного підпису та електронних протоколів справи; нормативно врегулювати запровадження електронного допиту.

6) Необхідно також здійснювати професійну підготовку користувачів електронного кримінально провадження (щоб в них були не лише юридичні знання, але й навички користування комп'ютером).

7) Створити процедуру перепису інформації на електронний носій.

Для створення та впровадження дійсно дієвого електронного кримінального провадження необхідно подолати зазначені проблеми. Також важливо поєднувати електронну і паперову форму, адже електронні пристрої та системи можуть виходити з ладу, або бути знищеними різноманітними вірусами та ін. Електронне кримінальне провадження не може повністю замінити звичайне кримінальне провадження, проте стовідсотково може стати його важливим елементом, оскільки зможе прискорити досудове розслідування, отримання погодження клопотань з боку прокурорів та слідчого судді та спростити вчинення інших процесуальних дій. Гарним європейським прикладом впровадження системи електронного кримінального провадження може слугувати Литва, Естонія та ін.

\section{Список використаних джерел:}

1. Студенников, С. (2019). Проблеми застосування електронного кримінального провадження: в Академії прокуратури відбувся круглий стіл. Судебно-юридическая газета. Вилучено 3 https://sud.ua/ru/news/publication/146845-problemi-zastosuvannya-elektronnogo-kriminalnogoprovadzhennya-v-akademiyi-prokuraturi-vidbuvsya-krugliy-stil.

2. Національна академія прокуратури України. (2019). В Академії відбувся круглий стіл «Електронне кримінальне провадження». Вилучено 3: http://napu.com.ua/uk/2019/07/vakademiyi-vidbuvsya-mizhnarodnyj-kruglyj-stil-elektronne-kryminalne-provadzhennyal.

\section{ПОДВІЙНЕ ГРОМАДЯНСТВО В УКРАЇНІ: ПРОБЛЕМНІ АСПЕКТИ}

Гердова кристина Олександрівна
студентка 4-го курсу
Дніпровський національний університет імені Олеся Гончара
Науковий керівник: Литвин О. П.
канд. юрид. наук, доцент
Дніпровський національний університет імені Олеся Гончара
УКРАїнА


наявна протягом усього існування нашої незалежної держави через недостатнє законодавче регулювання, проте наразі вона набула особливої актуальності.

Дослідженню інституту громадянства в Україні, зокрема феномену існування подвійного громадянства, присвячені праці таких науковців, як Толкачова І. А., Салей М. І., Радченко О. І., Васильківська В. В. та інших.

Взагалі подвійне громадянство (біпатризм, полігромадянство) - це перебування особи одночасно в громадянстві двох і більше держав. Дане явище може виникнути, коли особа умисно набуває громадянство декількох держав, а також у разі застосування різних законів про набуття громадянства. Наприклад, дитина, яка народилася на території держави, що застосовує принцип «права грунту», а від батьків, котрі $€$ громадянами держави, що застосовує принцип «права крові», отримує з моменту народження подвійне громадянство.

На думку автора, в Україні де-юре відсутня пряма заборона на подвійне або полігромадянство. У ст. 4 Конституції України закріплено, що в Україні існує єдине громадянство [1], у той же час ст. 2 Закону України «Про громадянство України» передбачено, що принцип єдиного громадянства виключає можливість існування громадянства адміністративнотериторіальних одиниць України. По суті, єдиною законодавчою нормою, яку можна тлумачити як опосередкований натяк держави на небажаність для неї наявність у її громадянина громадянства іншої держави або громадянства інших держав, є положення, що міститься у п. 1 ч. 1 ст. 19 вищезгаданого Закону: «Підставами для втрати громадянства України $є \ldots$ добровільне набуття громадянином України громадянства іншої держави, якщо на момент такого набуття він досяг повноліття» [2]. Проте у таких випадках виникає проблема необхідності доведення факту саме добровільного характеру набуття громадянином України громадянства іншої держави чи держав. Саме тому позбавити таку особу громадянства України майже неможливо, оскільки це суперечить законодавчо закріпленому принципу неможливості позбавлення українського громадянства за жодних обставин.

Наразі серед науковців існує дві діаметрально протилежні думки щодо такого явища, як біпатризм. Так, Ковальський В. стверджує, що отримання подвійного громадянства становить певну небезпеку для Української держави з ряду причин. По-перше, це економічний фактор. Особи, що вже мають таке громадянство, як правило, спекулюють на перетині кордону, тримаючи свої статки за кордоном, ведучи фактично подвійне життя. По-друге, це безпекові пріоритети. Власники подвійного громадянства становлять джерело непевності для країни свого перебування тим, що її національні інтереси зовсім не є для них пріоритетом [3]. Радченко О. І. стверджує, що за умови дружніх, добросусідських відносин між згаданими державами полігромадянство взагалі не становить проблеми. Але особливої гостроти проблема полігромадянства може набути в результаті недружніх дій однієї держави громадянства особи стосовно іншої, наприклад відкритої чи прихованої (гібридної) збройної агресії, що проявляється зокрема в анексії (захоплення) частини території одна одної, економічного, політичного тиску тощо [4].

Автор погоджується з думкою Макаренко Н. А., яка вважає, що наразі заборона подвійного громадянства $є$ недоречною з таких причин: 
1) гноруються інтереси представників етнічних меншин, що проживають на території України, деякі з них хотіли б мати громадянство тих країн, до яких вони етнічно належать (болгари, румуни, угорці, євреї);

2) більше 5 млн українських заробітчан працюють за кордоном. Більша їх частина працює нелегально, а в разі дозволу множинного громадянства вони зможуть отримати друге громадянство і працювати, отримуючи офріційну зарплату в іншій державі;

3) не враховуються взаємовідносини України і діаспорних груп. Етнічні українці пов'язують себе з Україною в різних країнах, і їхня ідентифікація проходить складно. I ця ідентифікація визначається в тому числі і наявністю паспорта. Діаспоряни багато допомагають зараз, а в перспективі можуть бути інвесторами і тими, хто колись захоче повернутися в Україну. I якщо у них буде паспорт України - це зробити їм буде набагато легше [5].

Якщо говорити про заборону полігромадянства, то в першу чергу це повинно стосуватися державних службовців, працівників органів державної влади, вищих посадових осіб правоохоронних органів, тобто осіб, у вірності яких громадяни України не повинні сумніватися. Адже наявність у вищезазначених посадовців громадянства іншої держави дає їм можливість у будь-який момент втекти з України і користуватися захистом країни другого громадянства. Необхідно зазначити, що наразі українським законодавством чітко не регламентована відповідальність перерахованих осіб за подвійне громадянство. Саме тому ми вважаємо, що забороняти полігромадянство та встановлювати відповідальність за порушення вимог Закону України «Про громадянство» в частині множинного громадянства для всіх $€$ недоречним. Але що стосується посадовців, украй важливо встановити жорсткі обмеження на перебування таких осіб в громадянстві іншої держави та чітко визначити відповідальність за їх порушення.

Отже, наразі подвійне громадянство в Україні залишається дискусійним питанням, на що впливають політичні, економічні, культурні та соціальні чинники. Але з часом ситуація буде тільки ускладнюватися, і в будь-якому випадку цю проблема потребуватиме вирішення або шляхом остаточної легалізації полігромадянства, або шляхом цілковитої законодавчої заборони, або запровадивши компромісний варіант для деяких держав.

\section{Список використаних джерел:}

1. Конституція України від 28.06.1996. № 254к/96-ВР. Вилучено 3 https://zakon.rada.gov.ua/laws/show/254k/96-вp.

2. Про громадянство України (Закон України). № 2235-III. (2019). Вилучено 3 https://zakon.rada.gov.ua/laws/show/2235-14.

3. Константиновський, С. (2018). Щодо питання множинного громадянства в Україні. Підприємництво, господарство і право, (5), 163-167.

4. Радченко, О. І. (2019). Заборона полігромадянства в Україні: перспективи запровадження та ймовірні наслідки. Правоохоронна фуннкия держави: теоретико-методологічні та історико-правові проблеми: тези доп. учасників міжнар. наук.-практ. конф. (м. Харків, 17 трав. 2019 р.), 177-179.

5. Макаренко, Н. А. (2017). Подвійне громадянство в Україні: проблеми та перспективи. Роль інновацій в транссоормації сучасної науки. Матеріали Міжнародної науково-практичної конфреренції (Київ, 29-30 грудня 2017 р), ч. 2, 66-68. 


\title{
ПОРІВНЯЛЬНИЙ АНАЛІЗ ПРОТИДІЇ ПОЛІТИЧНІЙ КОРУПЦІЇ В КРАÏНАХ ЄВРОПЕЙСЬКОГО СОЮЗУ ТА УКРАЇНІ
}

\author{
Данченко Катерина Михайлівна \\ старший викладач кафедри кримінально-правових \\ дисциплін та оперативно-розшукової діяльності \\ Прикарпатський фракультет (м. Івано-Франківськ) \\ Національної академії внутрішніх справ \\ Широкова Алла Анатоліївна \\ курсант 4-го курсу \\ Прикарпатський фракультет (м. Івано-Франківськ) \\ Національної академії внутрішніх справ \\ УКРАÏHA
}

Політична корупція як соціальне явище існує практично в усіх країнах світу, у тому числі в тих, що більшість дослідників їх відносять до "еталонних" з точки зору розвитку демократії. Так, на думку італійських дослідників Д.Дела Порта та А. Ванучі, до висококорумпованих країн світу належать Бельгія, Греція, Іспанія, Італія, а до “проміжних" - Австрія, США, Франція та Японія. Разом 3 тим особливого значення політична корупція набуває в суспільствах транзитивного типу, однією $з$ особливостей яких $€$ надмірна політизація державного управлінського апарату, якій значною мірою представляє не стільки інтереси держави та суспільства, скільки конкретних політичних угруповань, які, у свою чергу, тісно пов'язані з великим капіталом [1].

Аналіз останніх досліджень і публікацій. Проблеми політичної корупції вже достатньо тривалий час перебувають у полі зору вітчизняних дослідників. Зокрема, цьому питанню у своїх роботах приділяли увагу такі вітчизняні дослідники, як І. Сікора, Є. Невмержицький, А. Сафроненко, С. Телешун, Ю. Таран, В. Щербань та інші. Серед зарубіжних авторів, які розглядали проблеми політичної корупції в державах перехідного типу, у тому числі пострадянського простору, слід відзначити К.Уоллеса, К.Херфера, К. Х. Педерсена, Л. Иохансена, Р. Хислопа, А. Шайо та ін.

Проблемам політичної корупції у фаховій літературі приділяється достатньо багато уваги, проте питання, пов'язані з особливостями досвіду боротьби з політичною корупцією в $Є С$ в контексті запровадження відповідних практик в Україні, залишаються недостатньо дослідженими [1].

Метою статті $€$ порівняльний аналіз протидії політичній корупції в країнах Європейського союзу та Україні.

Корупція - одне найбільш деструктивних соціальних явищ, котре заважає оптимальному розвитку будь-якої держави, ефрективності державного управління та нормальному функціонуванню всіх соціальних інститутів. Зараз для України є одним з першочергових завдань саме мінімізація впливу даного фактору на процес реформування системи державного управління. 3 огляду на обраний євро інтеграційний шлях $є$ актуальним дослідження, визначення 
основних напрямків боротьби з корупцією та, насамперед, протидії їй. Це обумовлене тим, що європейські країни пройшли на цьому шляху далеко вперед та спромоглися звести до мінімуму рівень корумпованості [2].

Європейський союз хоча і $€$ наддержавним об'єднанням із спільною політикою та загальною стратегією розвитку, однак все одно кожна країна $€$ власний досвіду вирішенні питання корупції, звідси й відповідна специфіка.

Боротьба з корупцією у Великобританії

В теорії правничої науки у Великобританії можна відшукати велику кількість визначень корупції. Однак загальної дефініції, що фіксувалася би у законодавстві і застосовувалося б у практичній роботі правоохоронних органів немає. Першочергово, розгляд корупції за великим рахунком має кримінологічне або соціологічне підґрунтя, оскільки вона входить до переліку правопорушень та має вагомий вплив на суспільство.

Антикорупційна стратегія Великобританії поділяється: 1) поділ за сферою ії̈ прояву: банківська, політична, поліційна; 2) градація корупційних злочинів за ступенем зацікавленості населенням та розміром; 3) залучення банків до запобігання проявам корупції.

Найбільш небезпечною конфрігурацією корупційної діяльності визнається корупція політична. Найбільше вплив політичної корупції пов'язують 3 протизаконним або прихованим фінансуванням політичних партій чи політичних постатей. 3 метою подібного фінансування застосовуються доходи, отримані неправомірно, ухиленням від сплати податків, фріктивного банкрутства, шахрайства, застосування та прийняття фральшивих фінансових документів та інших правопорушень [3].

Якщо підсумувати, витоки корупції у Великобританії мають соціальне та культурологічне підґрунтя. Сама ж структура боротьби з корупцією $є$ досить дієвою та базується на тісній співпраці владних установ з приватним сектором.

Що ж стосується стратегії у боротьбі з політичною корупцією в Україні, то ВРУ від 17 липня 2019 року затвердила проект Закону України «Про засади державної антикорупційної політики в Україні (Антикорупційна стратегія) на 2019-2023 роки» [4].

Кінцевою метою всіх запланованих цією Антикорупційною стратегією заходів є забезпечення максимальної доброчесності усіх осіб, уповноважених на виконання функцій держави і місцевого самоврядування, прозорості діяльності державних інституцій, виявлення і нейтралізація існуючих нині в різних сфрерах корупціогенних ризиків, які становлять загрозу правам людини і функціонуванню держави, досягнення абсолютного неприйняття корупції суспільством - і врешті - решт відчутне зниження до 2023 року негативного впливу корупції в усіх відповідних сферах як фрактору побудови в Україні демократичної, соціальної, правової держави.

\section{Список використаних джерел:}

1. Тіньков, А. Л. Особливості протидії політичній корупції в країнах ЄС. Вилучено з http://www.academy.gov.ua/ej/ej14/txts/.

2. Беглиця, В. П. (2015). Досвід європейських країн щодо формування антикорупиійної cmpameiii.

(T. 263), $3 \mathrm{http}: / /$ nbuv.gov.ua/UJRN/Npchdu_2015_263_252_5.

(252),

17-23.

Вилучено 
3. Антошкин, В. К. (2011). Международная система контроля и противодействия коррупции. Вісник Бердянського університету менеджменту і бізнесу, 4(16), 22-27.

4. Які заходи боротьби з корупцією треба запровадити у наступні 5 років? Вилучено 3 https://rpr.org.ua/news/yaki-zakhody-borot-by-z-koruptsiieiu-treba-zaprovadyty-u-nastupni-5rokiv/.

\section{ПРАВОВА ПРИРОДА РЕЄСТРІВ НОТАРІАЛЬНИХ ДІЙ}

\section{Єлізаренко Каріна Хачатурівна}

здобувач вищої освіти юридичного фракультету Дніпровський національний університет імені Олеся Гончара

Науковий керівник: Щербина Євген Миколайович кандидат юридичних наук, доцент кафедри цивільного, трудового та господарського права Дніпровський національний університет імені Олеся Гончара УКРÄ̈̈A

Захист прав та законних інтересів громадян і юридичних осіб, запобігання правопорушенням - $€$ основним завданням нотаріату, авторитет і значення якого невпинно підвищується в умовах реформування соціально-економічних відносин. Без нотаріального посвідчення правочинів чи інших договорів неможливо уявити буденне життя. На основі нотаріально засвідчених документів відбуваються соціально-економічні правовідносини. Розвиток нотаріальної діяльності значною мірою залежить від покладених державою на органи нотаріату повноважень як щодо вчинення нотаріальних, так і вчинення інших дій, відмінних від нотаріальних, 3 метою надання їм юридичної вірогідності.

Нотаріат України вже давно звик до постійних реформ, однак зараз потребує якісних та глибинних трансформацій. Зміни в нотаріальній діяльності потрібні не стільки нотаріусам, скільки усьому суспільству, фізичним та юридичним особам, права та інтереси яких захищає нотаріат. Нотаріальна діяльність має превентивний характер і містить сукупність постійно або систематично здійснюваних публічних дій, спрямованих на юридичне закріплення безспірних цивільних прав і фрактів (надання офіційної сили, вірогідності юридичним правам, фрактам і документам), які виконуються органами нотаріату з метою забезпечення захисту прав і законних інтересів фізичних та юридичних осіб, які звернулися по вчинення нотаріальних дій та надання правової допомоги.

Під час здійснення своєї діяльності нотаріуси користуються доступом до низки електронних реєстрів, а саме до Єдиного реєстру нотаріусів, Єдиного реєстру спеціальних бланків нотаріальних документів, Державного реєстру обтяжень рухомого майна, Спадкового реєстру, Єдиного реєстру довіреностей, Державного реєстру речових прав на нерухоме майно, Державного реєстру актів цивільного стану громадян, Єдиного державного реєстру юридичних осіб, фрізичних осіб-підприємців та громадських 
формувань. Кожен нотаріус веде окремий реєстр. Запис в реєстрі $€$ безумовним доказом того, що нотаріальна дія вчинена. Загальний порядок ведення реєстрів для реєстрації нотаріальних дій та їх правова фрорма встановлюється Міністерством юстиції України. Водночас, у відповідності до останніх змін, які відбулися, Міністерство юстиції України координує та контролює ведення нотаріальних реєстрів. Всі ці Реєстри об'єднує спільна дія - реєстрація [3].

Нотаріус насамперед, повинен зосереджуватися виключно на юридичних аспектах своєї роботи, а саме на договорі, питаннях медіації у певних ситуаціях, законодавчому врегулюванні правочину. Сьогодні український нотаріус на перших етапах запровадження електронного нотаріату користується та працює з великою кількістю незручних електронних реєстрів, що змушує постійно відволікатися на технічні аспекти роботи з ними. Це створює купу проблем та підстав для зауважень з боку клієнтів та державних органів. Робота цих електронних реєстрів повинна бути набагато простішою, без технічних збоїв та проблем із функціонуванням, що давало б змогу нотаріусам більше часу для вчинення нотаріальної дії, а не ії фріксації та перевірки даних з реєстрів. Крім того, достовірність та повнота відомостей, внесених в окремі реєстри, є далекими від об'єктивної інформації.

Вчинення нотаріальної дії, як різновиду юридичної дії, проводиться не лише задля отримання певного результату - надання правам, фрактам, іншим діям юридичної вірогідності, а й для досягнення певної мети. Нотаріальна дія виникає за умови існування нормативного чи індивідуального юридичного факту. Характеризуючи правову природу реєстрів нотаріальних дій, які наразі існують в Україні, варто зазначити, що нотаріальне посвідчення будь-якого правочину чи вчинення іншої нотаріальної дії не $є$ втручанням нотаріуса у прийняті сторонами рішення щодо умов договору чи характер волевиявлення.

Питання порядку оформлення, ведення та заповнення реєстрів для реєстрації нотаріальних дій регулюється Законом України «Про нотаріат» та Правилами ведення нотаріального діловодства, затвердженими наказом Міністерства юстиції України від 22 грудня 2010 року № 3253/5 (далі Правила). Здійснення регулювання нотаріальних дій в Україні відноситься до компетенції основного Закону нашої держави - Конституції України. Конституція України проголосила перехід до формування вільної ринковоконкурентної економіки та демократичних принципів побудови державного устрою. Ці конституційні положення мають безпосередній зв'язок з нотаріатом, оскільки тепер землею можуть володіти не тільки держава, а й громадяни, юридичні особи, що зумовлює можливість переходу прав власності на такі об'єкти, що мають посвідчуватися в нотаріальному порядку. Ведення реєстрів нотаріальних дій вимагає дотримання головних умов, насамперед вимог статті 52 Закону України «Про нотаріат», окремих норм розділу VI «Складання та оформлення нотаріальних документів» та розділу VII «Порядок ведення та заповнення реєстрів для реєстрації нотаріальних дій» Правил [2].

У відповідності до вимог ст. 52 Закону України «Про нотаріат» про всі нотаріальні дії, вчинені нотаріусами, робиться запис у Реєстрах після того, як нотаріус зробить посвідчувальний напис на документі або підпише документ, що ним видається. Кожна нотаріальна дія реєструється за окремим порядковим номером [1]. Номер, за яким нотаріальна дія зареєстрована, зазначається на документі, що видається нотаріусом, чи в посвідчувальному 
написі. Особливою умовою для ведення Реєстрів є заповнення від руки чорнилом або кульковою ручкою чорного, синього або фіолетового кольору 3 дотриманням всіх технічних умов, визначених Законом та Правилами [2].

Записи в Реєстрі проводяться особисто нотаріусом чи в його присутності працівником державної нотаріальної контори або особою, яка перебуває в трудових відносинах з приватним нотаріусом. На сьогодні при здійсненні своєї діяльності нотаріуси користуються доступом до ряду електронних реєстрів. А саме: Єдиного реєстру нотаріусів, Єдиного реєстру спеціальних бланків нотаріальних документів, Державного реєстру обтяжень рухомого майна, Спадкового реєстру, Єдиного реєстру довіреностей, Державного реєстру речових прав на нерухоме майно, Державного реєстру актів цивільного стану громадян, Єдиного державного реєстру юридичних осіб, фрізичних осібпідприємців та громадських формувань. Це невичерпний перелік, нові нормативно-правові акти запроваджують все нові і нові реєстри. Будь-які реєстри, що запроваджуються нормативно-правовими актами слід вважати правовими, до того ж інформаційні довідки, що надаються з таких реєстрів $є$ доказовою базою у будь-яких спорах [4].

Ситуація, яка склалась в нотаріаті України, досить нетипова, адже наразі державний та приватний нотаріат має однакові повноваження - 3 точки зору особи, яка звертається до нотаріуса. Разом з тим, оскільки державним нотаріатом безпосередньо опікується регулятор, існують проблеми із матеріально-технічним забезпеченням державних нотаріальних контор, оплата праці державних нотаріусів недостатня, низку ДНК взагалі ліквідували. Найкращий вихід із цієї ситуації - запровадження, врешті, єдиного нотаріату, на базі приватного. Щоб прийняти таке рішення, потрібна політична воля та виваженість. Нотаріат $€$ не лише складовою економічної та соціальної структур суспільства, враховуючи специфіку нотаріальної діяльності та еволюцію розвитку, він посідає чільне місце у сфері громадянського суспільства, оскільки його функції спрямовані на охорону та захист законних прав та інтересів, особливо у приватному житті. Створення єдиного реєстру нотаріальних дій дозволить оптимізувати роботу нотаріусів. Адже в електронній базі буде набагато простіше знайти необхідний документ. За деякими документами громадянам не потрібно буде приходити, щоб взяти або посвідчити їх вдруге, оскільки вони зможуть самостійно переглядати необхідні папери та отримувати копії. Також допоможе в роботі застосування Електронного цифрового підпису (ЕЦП), що передбачає наявність легкого доступу до відомостей про особу, бізнес та документів, які стосуються громадянина.

Таким чином, інститут нотаріату як відповідний державний орган, має на меті забезпечувати реальну реалізацію прав і обов'язків відповідних осіб, які звернулись за вчиненням юридичної дії, а в разі потреби охороняти і захищати права та інтереси відповідних осіб. Будь який із нотаріальних реєстрів, що знаходиться в розпорядженні нотаріуса повинен вестися із дотриманням чіткої процедури ведення, визначеної законодавством. Наразі особлива увага приділена електронному реєстру - Е-нотаріату. Електронний реєстр нотаріальних дій розробляє та впроваджує професійна самоврядна організація - Нотаріальна палата України. Масштабні проекти з впровадження та реалізації інформаційних технологій у всіх сферах правовідносин підтверджують необхідність використання електронних засобів зв'язку, інструментів інформаційно-комунікаційних технологій у такій традиційно 
«паперовій» сфері як нотаріат. Електронний нотаріат - це і створення єдиного електронного реєстру нотаріальних дій, і використання електронного цифрового підпису (ЕЦП), і оцифровка нотаріальних документів, і створення бази для електронного архіву. Сьогодні навіть з ухваленням законів «Про електронний цифровий підпис», «Про електронні документи та електронний документообіг» немає жодних підстав говорити про можливість впровадження електронного нотаріату, оскільки в цьому напрямку має бути змінено ЗУ «Про нотаріат» [5].

Отже, визначальним фрактором нотаріальної діяльності є й залишається інфрормаційний аспект змісту такої діяльності. Правова природа реєстрів нотаріальної дії має випливати із юридичної сутності інституту нотаріату. Всі реєстри, які створюються на підставі положень нормативно-правових актів $€$ правовими, оскільки вони містять інформацію, яка породжує, змінює, припиняє або підтверджує існування певних прав чи юридичних фактів.

\section{Список використаних джерел:}

1. Про нотаріат (Закон України), № 3425-ХІІ, від 02.09.2003 р. (редакція від 18.10.2019). (2019). Вилучено з https://zakon.rada.gov.ua/laws/show/3425-12.

2. Правила ведення нотаріального діловодства (Наказ Міністерства юстиції України), № 3253/5, від 22 грудня 2010 (редакція від 27.08.2019). (2019). Вилучено 3 https://zakon.rada.gov.ua/laws/show/z1318-10.

3. Денисяк, Н. М. (2017). Правові засади діяльності нотаріату за законодавством України: матеріальний та процесуальний аспекти. Одеса.

4. Долинська, М. С. (2015). Українське нотаріальне право. Київ: Юрінком Інтер.

5. Єфіменко, Л. В. (2017). Особливості правової природи нотаріальних дій. Київ: Юридична Україна.

DOI 10.36074/25.10.2019.v3.08

\section{ПРАВОВЕ ЗАБЕЗПЕЧЕННЯ ФІНАНСОВОЇ БЕЗПЕКИ}

Храпкіна Валентина Валентинівна

д-р. екон. наук, профресор, професор кафедри маркетингу і управління бізнесом Національний університет «Києво-Могилянська Академія»

Стратонов Василь Миколайович д-р. юрид. наук, професор, професор кафедри Херсонський державний університет

УКРÄ̈̈A

Забезпечення безпеки $є$ однією з найскладніших теоретико-прикладних проблем, яка за своєю суттю має всеохоплюючий характер і $€$ в рівній мірі актуальною як для окремої людини, суб'єкта господарювання, держави, так і світового співтовариства в цілому.

Безпека, як юридичне та економічне поняття, відображає національні інтереси, пов'язані зі збереженням сформованих економіко-правових відносин 
у певній державі або на конкретній території та з необхідністю їх захисту від будь-яких зовнішніх і внутрішніх посягань.

Нині в Україні не існує єдиного нормативно-правового акту, в якому були б закріпленні всі положення, що стосуються забезпечення фінансової безпеки держави. Проте є законодавчі акти, які містять загальні положення, що стосуються безпеки держави загалом, а також в яких згадується про фрінансову безпеку.

Базовим нормативно-правовим актом у сфері безпеки є Закон України «Про національну безпеку України» [1], який визначає основні засади державної політики, спрямованої на захист національних інтересів і гарантування в Україні безпеки особи, суспільства і держави від зовнішніх і внутрішніх загроз в усіх сферах життєдіяльності. Правове забезпечення фінансової безпеки базується на Концепції забезпечення національної безпеки у фінансовій сфері від 15.08.2012 року [2].

Поняття фінансової безпеки представлено у Методичних рекомендаціях щодо розрахунку рівня економічної безпеки України, затверджених Наказом Міністерства економічного розвитку і торгівлі України в 2013 році. Відповідно до них фінансова безпека - це стан фінансової системи країни, за якого створюються необхідні фрінансові умови для стабільного соціальноекономічного розвитку країни, забезпечується її стійкість до фрінансових шоків та дисбалансів, створюються умови для збереження цілісності та єдності фінансової системи країни [3].

За даними міжнародних організацій у багатьох світових рейтингах останніх років Україна посідає останні місця у сфері забезпечення безпеки чи їі окремих елементів [4].

3 прискоренням інтеграції економіки України у світову економіку підвищується ймовірність зовнішніх загроз для фінансової безпеки України, адже на початку економічної кризи відбувається відтік капіталу за кордон, що призводить до девальвації національної валюти, активізації інфляційних процесів та дестабілізації економічної системи [5].

Підсумовуючи вищезазначене, потрібно зауважити, що низький рівень законодавчого забезпечення фрінансової безпеки держави обумовлений неефективністю державного управління, його недостатньою зорієнтованістю на захист національних інтересів в економічній і соціальній сферах, непослідовністю та безсистемністю у здійсненні реформ, недосконалістю національного законодавства щодо забезпечення фінансової безпеки держави; недостатнім рівнем кваліфікації державних службовців з питань забезпечення національної безпеки тощо.

Така ситуація вимагає перегляду підходів до змісту фінансової безпеки, розробки концептуальних засад побудови системи фінансової безпеки в державі, стратегії ії забезпечення та відповідальності.

\section{Список використаних джерел:}

1. Про національну безпеку України (Закон України), 2469-VIII, від 21.06.2018. (2018). Вилучено з https://zakon.rada.gov.ua/laws/show/2469-19. 
2. Концепція забезпечення національної безпеки у фінансовій сфрері (Розпорядження Кабінету Міністрів України), № 569-р, від 15.08 .2012 р. (2012). Вилучено 3 http://zakon3.rada.gov.ua/laws/card/569-2012-\%D1\%80.

3. Методичні рекомендації щодо розрахунку рівня економічної безпеки України (Наказ Міністерства економічного розвитку і торгівлі України), № 1277, від 29.10.2013. (2013). Вилучено 3 http://www.nau.kiev.ua/index.php?page=hotline\&file=449309-29102013-0.htm. $\begin{array}{lll}\text { 4. } & \text { Індекс } \quad \text { економічної } \\ \text { http://www.heritage.org/index/pdf/.../countries/ukraine.pdf. }\end{array}$

5. Крупка, І.М.(2012). Фінансово-економічна безпека банківської системи України та перспективи розвитку національної економіки. Бізнес інфрорм, (6), 168-175.

\title{
ПРАВОВЕ РЕГУЛЮВАННЯ ТРУДОВОЇ ДОПОМОГИ БЕЗРОБІТНИМ В УСРР В ПЕРІОД НОВОЇ ЕКОНОМІЧНОЇ ПОЛІТИКИ (1921-1929 рр.)
}

\begin{abstract}
Харасик Наталія Олегівна
асистент кафредри історії держави і права України та зарубіжних країн Національний юридичний університет ім. Ярослава Мудрого
\end{abstract}

УКРÄ̈̈A

Нова економічна політика передбачала запровадження вільного ринку праці, що неминуче призвело до стрімкого зростання кількості безробітних. Партійним керівництвом держави було прийнято рішення про відновлення бірж праці, на які покладались посередницькі фрункції 3 працевлаштування, реєстрація безробітних, направлення їх на роботу за заявками роботодавців, надання допомоги у зв'язку із безробіттям.

Допомога безробітним розподілялась на грошову, натуральну та трудову. До трудової допомоги належали: створення колективів безробітних, артілей, організація курсів для перекваліфікації та перенавчання безробітних, які мали спеціальності, що не користувалися попитом на ринку праці, а також організація громадських робіт.

Основним видом трудової допомоги була організація колективів безробітних, які являли собою досить високий рівень організації тимчасової зайнятості безробітних. Колективи створювалися з числа безробітних, які були зареєстровані на біржі праці, та в залежності від характеру праці поділялися на виробничі, торговельні та трудові.

Склад колективів був непостійним. Змінність складу була покликана необхідністю надання трудової допомоги якомога більшій кількості безробітних. Тому термін перебування безробітного у колективі був обмеженим - у виробничих колективах - шість місяців, у трудових i торговельних - три місяці. Припускалася наявність у колективах постійного складу 3 числа кваліфікованих працівників, які замінювалися іншими безробітними лише у випадку їхнього переходу на постійну роботу. Це забезпечувало нормальне функціонування підприємств. Основний постійний 
склад не повинен був перевищувати 20 відсотків від загальної кількості зайнятих у колективі безробітних. У трудових колективах принцип змінності проводився більш повно, і створення постійного складу не дозволялося.

Правовий статус колективів визначався Тимчасовим положенням, затвердженим постановою ВУЦВК та РНК УСРР від 23 травня 1925 року [1]. Згідно цього положення окремі колективи та їх об'єднання діяли на підставі статутів, які реєструвалися Комітетами бірж праці. Прибуток окремого колективу розподілявся таким чином: 25 відсотків надходило на розгортання діяльності того ж самого колективу, 10 відсотків відраховувалося на користь об'єднання колективів, якщо даний колектив входив до об'єднання, решта коштів надходила до Комітету біржі праці на розширення трудової допомоги безробітним. Підприємства і колективи, які утворювалися при одній біржі праці складали об'єднання, на чолі якого стояли правління або одноосібний управляючий.

Учасники колективу на весь час роботи у ньому залишались на обліку біржі праці і не втрачали своєї черги.

Трудові і виробничі колективи безробітних звільнялися від усіх податків і зборів протягом шести місяців від дня утворення, у тому числі і від внесків на соціальне страхування, хоча усі види соціального страхування для членів колективу зберігались. Усі установи при біржі праці - гуртожитки, їдальні, ясла, які обслуговували лише безробітних, зареєстрованих на біржі праці, звільнялися від внесків на соціальне страхування і від сплати комунальних послуг. Після закінчення пільгового періоду до колективів застосовувалось оподаткування кустарно-промислової кооперації. Колективи не могли конкурувати з державними та кооперативними підприємствами, оскільки мали на меті лише допомогу безробітним, не здатним отримати роботу. Саме тому ці колективи мали пільги.

Розмір заробітної плати працюючих у колективах безробітних визначався тарифною угодою, яка укладалась між правлінням об'єднання та тією профспілкою, до якої належала певна категорія безробітних. Розмір винагороди визначався у залежності від наявності коштів. В середньому заробітна плата у виробничих і трудових колективах в становила 35-50 крб. на місяць, і відповідала заробітку некваліфікованого робітника. Відпустки надавалися у розмірі двох тижнів особам, які відпрацювали не менше 11,5 місяців. Неповнолітнім відпустка надавалась через 11 місяців роботи терміном на один місяць. У разі неможливості надання відпустки, компенсація видавалась на загальних підставах.

Позитивним моментом було те, що колективи безробітних у низці випадків відновлювали недіючі підприємства. Зміцнілі колективи із кількістю працівників 20 осіб, які відпрацювали звітний рік бездефіцитно, передавалися господарським органам i включалися до числа підприємств місцевої промисловості. Безробітні в цьому випадку отримували статус постійних працівників і знімалися з обліку біржі праці. Змінюваність складу працюючих у цьому випадку на даному підприємстві скасовувалась.

Іншим заходом щодо ліквідації безробіття була організація громадських робіт. Це роботи, які виконувались з метою надання допомоги безробітним, і організовувались органами Народного комісаріату праці на спеціальні кошти, 
які надавала держава або громадські організації. Зазвичай це були роботи, матеріал для яких вимагав менше коштів, ніж робоча сила або важкі роботи.

До громадських робіт належали: - праця у паркових та садових господарствах (очищення парків, садів, праця в оранжереях, парниках тощо); - земляні роботи; - ремонт скверів (ремонт стежок, створення газонів); облаштування нових скверів; - ремонт доріг, очищення засмічених канав, прибирання вулиць, розбір зруйнованих будинків тощо. До таких робіт залучалися безробітні, які були зареєстровані на біржах праці зі складу некваліфікованих робітників з допущенням кваліфікованих не більше, ніж 20 відсотків від загальної кількості складу. Направлення безробітних на громадські роботи здійснювалось біржею праці. У першу чергу робота пропонувалась членам профсспілок, самотнім жінкам та особам, які були звільненні з лав Червоної армії та фрлоту. При направленні на громадські роботи оголошувався добровольчий запис. У випадках, коли за добровольчим записом потреба у працівниках не була задоволена повністю, біржам праці надавалось право направляти безробітних на громадські роботи за чергою. Від направлення на громадські роботи позбавлялись чоловіки старше 55 років, жінки старше 40 років; інваліди, які втратили працездатність більше, ніж на $50 \%$; жінки на 5 місяці вагітності та жінки, які годували груддю; безробітні, які представили посвідчення про хворобу. Поважною причиною відмови від громадських робіт також вважалось направлення працівника не за спеціальністю терміном більше, ніж на два місяці.

Якщо кваліфікований працівник відмовлявся від виконання громадських робіт вперше, він позбавлявся усіх видів допомоги по безробіттю; вдруге пересувався на кінець черги. Якщо відмовлялись некваліфіковані працівники, металісти до 4 розряду, інших професій до 6 розряду вперше, вони позбавлялись допомоги по безробіттю та пересувались на кінець черги; вдруге - знімалися з обліку із забороною реєструватися на біржі праці в якості безробітного терміном до трьох місяців. Безробітні, які виконували громадські роботи продовжували перебувати на обліку біржі праці та через деякий час змінювались іншими безробітними. Протягом одного сезону відбувалось не менше однієї зміни. Однак зміна до спливу місячного терміну не рекомендувалась. Розмір винагороди безробітних, які були зайняті на громадських роботах, встановлювала адміністрація цих робіт. Вартість робочої сили повинна була складати не менше 70 відсотків вартості робіт, і лише у виключних випадках - 50 відсотків, але ні в якому разі не могла перевищувати розцінок, існуючих на схожих роботах у госпорганах. Керівництво громадськими роботами та нагляд за ними здійснювали біржі праці.

Велика увага приділялася адаптації безробітних на підприємстві. При біржах створювалися експертні комісії для визначення професії та кваліфікації робітників та службовців, які були звільнені у зв'язку із скороченням штатів рівня їхньої реальної кваліфікації шляхом проведення експертизи, практичного випробування на виробництві. Вони давали відповідні рекомендації та консультації усім, хто звертався до них. Якщо вакансії, які були, не зовсім відповідали професії та рівню кваліфікації, бажаючих отримати роботу направляли на спеціальні курси, де проводилася професійна підготовка. 
Висновки. Із введенням вільного ринку праці радянська держава не мала можливості подолати зростаюче безробіття. Проте тимчасова зайнятість безробітних була дуже необхідним та корисним заходом, що надавало можливість безробітним не втратити кваліфікацію та забезпечувало хоча б невеличку матеріальну підтримку.

\title{
Список використаних джерел:
}

1. ЗУ УСРР. (1925). Тимчасове положення про колективи безробітних, № 27 від 23 травня 1925 p. (ст. 217).

2. О проверке, экспертизе и практическом испытании профессиональной подготовки ищущих труда: Инструкция Наркомтруда СССР № 28. (1923). Известия НКТ УССР, (3/27).

\section{ПРАВОВІ ЗАСАДИ САМОРЕГУЛЮВАННЯ СУСПІЛЬНИХ ВІДНОСИН В ІНФОРМАЦІЙНІЙ СФЕРІ УКРАЇНИ}

\author{
Маріц Дарія Олександрівна
}

канд. юрид. наук, доцент, доцент кафедри інформаційного права та права інтелектуальної власності Національний технічний університет України «Київський політехнічний інститут імені Ігоря Сікорського»

УКРÄ̈HA

Правове регулювання суспільних відносин, як відомо, здійснюється за принципом загального (нормативного) або індивідуального регулювання. Хоча, в юридичній літературі з теорії держави і права, договірне регулювання ототожнюють із саморегулюванням [1]. Однак, у сфрері інформаційних відносин, договір не єдина підстава виникнення правовідносин та правова форма, яка опосередковує індивідуальне регулювання. Суб'єкти інформаційних відносин, залежно від сфрери їх діяльності, наділяються правом об'єднуватися у саморегулівні організації, участь в яких є добровільною (або обов'язковою, якщо це прямо передбачено законом), а умови вступу, участі, дотримання умов Етичного кодексу $є$ загальнообов'язковими для всіх його учасників. Тобто, саморегулювання визначає межі дозволеної поведінки, рамки якої обумовлює відповідний локальний нормативно-правовий акт, професійний Етичний кодекс.

Питання, які пов'язані із саморегулюванням суспільних відносин стосуються не лише заявленої тематики цієї публікації. На порядку денному багатьох науково-практичних заходів підіймаються питання, що пов'язані із створенням єдиного саморегулюючого органу зокрема у сфері арбітражних керуючих [2]. Однак не зважаючи на різні вектори діяльності саморегулюючих організацій, варто зазначити, що спільним для всіх $€$ те, що саморегулювання дозволяє більш природно і професійно підходити до розбудови будь-якої професії, пов'язаної з наданням специфічних послуг громадянам [3]. 
Так, Кабінет Міністрів України (далі - КМУ) у розпорядженні «Про затвердження плану заходів з реалізації Концепції реформування інституту саморегулювання в Україні» від 29 серпня 2018 р. № 598-р визначив зміст заходів та завдань, а також строк їх виконання відповідальними особами. Одним із завдань розпорядження було розроблення проекту Закону щодо саморегулювання в Україні. Із тексту Концепції рефрормування інституту саморегулювання в Україні випливає, що саморегулювання згідно спеціального законодавства можливе у 15 сферах. Разом з тим, констатується необхідність подальшого розвитку саморегулювання в інформаційній сфері, зокрема що пов'язано із рекламною діяльністю та діяльністю засобів масової інформації. Повертаючись до законодавчої регламентації відносин у сфері саморегулювання, то 11.12.2014 року у Верховній Раді України було зареєстровано проект Закону України «Про саморегулювальні організації» під номером 1444. Своєю чергою, на офріційному сайті Мінекономрозвитку 28.12.2018 року запропоновано на обговорення редакцію Закону України «Про саморегулівні організації». Згідно останнього проекту Закону під саморегулівною організацією пропонується розуміти - об'єднання суб'єктів господарювання або суб'єктів професійної діяльності для саморегулювання у визначених законом формах та межах здійснюваної ними господарської або професійної діяльності відповідно, представництва і захисту своїх прав та інтересів. Так, відповідно до ч. 4 ст. 2 зазначеного проекту чітко визначено на які суспільні відносини не може поширюватись дія цього Закону. Зокрема, що стосується утворення, діяльності та припинення громадських об'єднань, професійних спілок, організацій роботодавців, творчих спілок, інших непідприємницьких товариств, які не є саморегулівними організаціями. Отже, постає важливе теоретичне питання щодо необхідності визначення організаційно-правового статусу саморегулівної організації.

В інформаційній сфрері на сьогодні існує Комісія з журналістської етики - орган саморегуляції роботи журналістів та редакцій, який дозволяє обговорювати та пропонувати шляхи вирішення конфлліктних ситуацій базуючись на єдиному стандарті роботи. Комісія розглядає конфліктні ситуації етичного та професійного характеру, які виникають в журналістському середовищі та між цим середовищем та громадськістю у зв'язку з виконанням журналістами свого професійного обов'язку. У своїй діяльності Комісія керується Кодексом етики українського журналіста.

Існують і інші об'єднання, наприклад Асоціація операторів зовнішньої реклами України. Однак, ця організація зареєстрована як громадська спілка, а не як орган саморегулювання. Своєю чергою Проект ЗУ «Про саморегулівні організації» у перехідних та прикінцевих положеннях передбачає, що зареєстровані на момент набрання чинності цим Законом господарські об'єднання, громадські спілки, громадські організації, які об'єднують суб'єктів господарської або професійної діяльності у певній сфері та мають намір здійснювати свою діяльність як саморегулівні організації, набувають статусу саморегулівної організації без зміни організаційно-правової фрорми у разі приведення їх статуту у відповідність із вимогами цього Закону, створення органів управління, передбачених цим Законом, та прийняття правил саморегулівної організації (за бажанням вони можуть також реорганізуватися у саморегулівну організацію шляхом перетворення). 
Правовий статус саморегулівних організацій на сьогодні визначити однозначно досить складно. Оскільки відсутнє їх загальне правове регулювання, а представлені тези доповіді базуються лише на проектах нормативно-правових актів. Однак, відштовхуючись від Модельного закону СНД «»Про саморегулівні організації» та проекту ЗУ «Про саморегулівні організації» можна визначити наступні ознаки СРО: 1) це об'єднання юридичних осіб приватного права або суб'єктів професійної діяльності; 2) $€$ неприбутковою (непідприємницькою) організацією; 3) за загальним правилом утворюється на засадах добровільного членства; 4) об'єднує учасників за сферою спільної діяльності; 5) саморегулівна організація розробляє та керується обов'язковими для всіх її учасників правила, стандарти, кодекси; 6) за організаційно-правовою фрормою утворюється як організація господарського саморегулювання або організація професійного самоврядування. Однак, не вирішеним залишається питання мінімальної кількості учасників такої організації, за якої вона може бути визнана як саморегульована.

\section{Список використаних джерел:}

1. Скакун, О.Ф. (2010). Теорія права і держави. К: Правова єдність. Вилучено 3 https://westudents.com.ua/glavy/70070-6-vidi-pravovogo-regulyuvannya-susplnih-vdnosin.html.

2. Донков, С. (2019). Саморегулювання арбітражних керуючих: чекати чи будувати? Юридична газета online, 9(663). Вилучено 3 http://yur-gazeta.com/publications/practice/bankrutstvoirestrukturizaciya/samoregulyuvannya-arbitrazhnih-keruyuchih-chekati-chi-buduvati.html.

3. Бірюков, О. (2019). Саморегулювання створюється не для покарання. Банкрутсво\&Ліківдація в Україні. Вилучено з https://bankruptcy-ua.com/articles/11338.

\section{ПРЕЗИДЕНТ УКРАЇНИ, ЙОГО РОЛЬ ТА МОЖЛИВІСТЬ УСУНЕННЯ 3 ПОСАДИ В ПОРЯДКУ ІМПІЧМЕНТУ}

Кривульський Данило Сергійович Дніпровський національний університет імені Олеся Гончара

Науковий керівник: Чукаєва В.О. кандидат історичних наук, доцент Дніпровський національний університет імені Олеся Гончара УКРӒ̈HA

Як відомо, сутність демократії полягає в можливості народу здійснювати управління державними справами як безпосередньо, так і через обраних ним посадових осіб. Щодо останніх то вони в свою чергу є виконавцями народної волі, а тому несуть відповідальність, якщо з тих чи інших причин цю волю не виконують.

Особливе місце серед владних інститутів в Україні займає Президент України. Він не належить до жодної з трьох гілок влади, однак його роль в управлінні державою є дуже великою, ба навіть головною. Незважаючи на те, 
що Україна є парламентсько-президентською республікою, однак на практиці спостерігаємо певну тенденцію до підпорядкованості вищого законодавчого органу держави президентові. Головним чином це відбувається завдяки наявності у останнього близької до нього потужної політичної фракції у парламенті. Найбільш яскравим прикладом $є$ нинішня пропрезидентська монобільшість із представників фракції політичної партії «Слуга народу».

Зрозуміло, що перебування «своїх» людей у парламенті дозволяє президентові досить оперативно протягувати власні законодавчі ініціативи. I хоча це, з одного боку, може сприяти швидкому й ефективному вирішенню наявних проблем у державі, однак, з іншого боку, не слід забувати про загрозу узурпації влади, яка несе безпосередню шкоду як парламентаризму, так і демократії в цілому.

Варто зазначити що цього року відбулася важлива і довгоочікувана подія прийняття Верховною Радою України Закону України «Про особливу процедуру усунення Президента України з поста (імпічмент). До цього процедура усунення Президента України в порядку імпічменту була задекларована у ст.111 Конституції України [1], проте очевидною була необхідність деталізації положень даної статті у окремому законі.

Даний законопроект був поданий самим чинним президентом, що, на нашу думку, можна розцінювати як жест його готовності нести відповідальність за свої дії.

Однак, Закон все ж таки викликає серйозні питання. Зокрема, сама процедура усунення глави держави з поста є занадто складною. Ії̈ порядок виглядає наступним чином:

- подання Верховної Ради про вчинений президентом злочин;

- голосування Ради за оголошення початку процедури імпічменту i створення тимчасової комісії (необхідно щонайменше 301 голос "за");

- формування тимчасової слідчої комісії;

- комісія проводить розслідування фракту та обставин злочину;

- слідча комісія готує і подає до Ради висновки і пропозиції щодо проведеного розслідування;

- розгляд Радою висновків комісії за участі президента, голови та суддів КСУ, голів ВСУ та ГПУ і уповноваженої ВРУ з прав людини;

- Рада голосує за подання висновків ТСК та результатів обговорення до ВСУ та КСУ (голосування таємне, потрібно $300+1$ голос);

- ВСУ та КСУ розглядають подання Верховної Ради;

- Рада ухвалює рішення про усунення президента з поста (голосування таємне, потрібно 338 і більше голосів);

- президент втрачає повноваження після оголошення про це головою парламенту [2].

Як бачимо, процедура імпічменту вимагає неабиякої консолідації у Верховній Раді проти глави держави. Видається малоймовірним назбирати 338 голосів при прийнятті остаточного рішення. Проте, на нашу думку, таке все ж таки можливо у разі вчинення президентом протиправного діяння, яке суттєво зашкодить інтересам України та зробить його персону настільки неприйнятною суспільством, що будь-які кроки на його підтримку тягнутимуть втрату довіри до народного депутата, який таку підтримку висловить. 
3 іншого боку, в українських реаліях, можливо, така складність процедури і вимога такої великої кількості голосів народних депутатів при усуненні президента з поста $€$ виправданими, оскільки це слугує запобіжником від ймовірних намагань окремих політичних сил тиснути на главу держави та дестабілізувати політичну ситуацію.

Отже, Президент України є фрактично головним владним інститутом у нашій державі, оскільки, незважаючи на парламентсько-президентську форму правління, наразі майже усі ініціативи глави держави мають підтримку у парламенті завдяки представленості там більшості із депутатів президентської партії. I хоча в таких умовах великою $є$ загроза узурпації влади, на практиці можемо спостерігати позитивні зміни у діяльності інституту глави держави. Головною такою зміною є прийняття закону про імпічмент президента, якого не існувало протягом усього часу незалежності України. Це викликає стриманий оптимізм та сподівання на подальшу демократизацію державного устрою в нашій державі.

\section{Список використаних джерел:}

1. Конституція України, 254к/96-ВР, від 28.06.1996 р. (у редакції від 21.02.2019). (2019). Вилучено 3 https://zakon.rada.gov.ua/laws/show/254к/96-вр.

2. Закон про імпічмент: що це означає і чи буде він дієвим. (2019). Вилучено $з$ https://24tv.ua/zakon_pro_impichment_prezidenta_shho_tse_chi_bude_pratsyuvati_zakon_n12 03392.

DOI 10.36074/25.10.2019.v3.10

\section{ПРО СУТНІСТЬ ОЗНАК, ЩО ХАРАКТЕРИЗУЮТЬ ЮРИДИЧНИЙ ФАКТ}

Остапенко Леонід Олексійович

кандидат юридичних наук, доцент кафедри цивільного права та процесу, Навчально-наукового інституту права, психології інноваційних технологій Національний університет «Львівська політехніка»

УКРӒ̈HA

Вольова ознака як критерій, що характеризує юридичні факти у трудових правовідносинах повинна бути належним чином встановлена і зафіксована.

Вольова природа юридичних фактів у трудовому праві передбачає певний інтерес і мету суб'єктів трудових відносин. Вольові дії суб'єктів у їх юридичному значенні стають юридично значимими за умови настання правових наслідків. Так, дискримінують у сфері праці (ст.2-1 КЗпП України) за умови якщо вона вчинена відносно фізичної особи стає юридично значимою при її правовій фріксації і передбачає настання певних юридичних наслідків, що покликані поновлення права людини на працю.

Дещо іншим є галузевий підхід у визначенні загальних та особливих ознак юридичних фактів у податковому праві. 
На думку І.О. Пасічної юридичні факти у податковому праві мають такі ознаки: 1) зовнішня вираженість; 2) інформаційність (несуть інформацію про стан суспільних відносин); 3) конкретність та індивідуальність (існують у повній точці простору і часу); 4) нормативна визначеність (безпосередньо передбачені гіпотезами нормами податкового права); 5) спричиненість наслідків (спричиняють настання передбачених науково-правовою нормою правових наслідків у податковій дійсності - виникнення, змін чи припинення податкових правовідносин).

До спеціальних ознак юридичних фактів І. О. Пасічна відносить: 1) конструктивність (забезпечують перетворення (конструювання) нормативної моделі податкових правовідносин у фрактичні податкові правовідносини; 2) можливість незбігу з наслідками (існування юридичного факту не завжди збігається у часі 3 виникненням юридичних наслідків у податковій діяльності; 3) фіктивність (можуть бути юридичними фактами моделями, що існують незалежно від юридичних фрактів; 4) оформленість (можуть спричиняти юридичні наслідки у податковій дійсності лише за їх належного офрормлення) [1].

Наведений нами перелік ознак, що характеризують поняття юридичного факту i його важливість у регулюванні правових відносинна думку Н.М. Марченка та Є.М. Дерябіної полягає в тому, що вони :

1) $€$ різними життєвими обставинами, умовами та фрактами; 2) визначаються в гіпотезах норм права; 3) $€$ неодмінною умовою винекнення зміни або припинення правових відносин; 4) зумовлюють суб 'єктами права та юридичні обов 'язки учасників правових відносин; 5) забезпезпечуються державним примусом [2; 3]; 6) інформують про стан суспільних відносин, які входять у предмет правового регулювання; 7) умовний спосіб виражені зовні (об'єктивовані); 8) прямо побічно передбачені нормами права; 9) характерезують наявність або відсутність певних явищ матеріального світу; 10) зафріксовані встановлені законодавством процедурно-процесуальній формі; 11) зумовлюють передбачені законом правові наслідки, передусім виникнення, зміну або припинення правових відносин [4].

Погоджуючись в принципі з наведеними ознаками, які характеризують юридичні факти звернемо увагу на їх різноманітність та галузеву належність, що негативно впливає на вироблення єдиних підходів у визначенні поняття юридичного факта. Для юридичного факта важливою є ознака, що передбачає його фрормування на підставі дії чи бездіяльності під час реалізації яких виникають права, обов'язки та правові наслідки, що впливають на виникнення, зміну та припинення трудових відносин. Кожен з елементів юридичних фактів маючи між собою логічно- послідовний зв'язок не має можливості сприяти виникненню і завершенню трудових відносин. Виникає своєрідна правова «прогалина», яка унеможливлює формування юридичного факта або впливає на створення окремого відносно самостійного факта.

Для юридичних фактів важливим $є$ логічно обумовлений послідовний порядок накопичення елементів, за умови щоб між ними не виникало самостійних правовідносин, які передбачають права та обов'язки між ними.

Отже, юридичними фактами у трудовому праві слід вважати обставини, які впливають на виникнення, зміну та припинення трудових відносин шляхом їх нормативно-правового закріплення. Юридичні наслідки $є$ результатом 
правомірних чи навпаки, неправомірних дій суб'єктів трудових відносин і впливають на їх виникнення, зміну або припинення.

Правомірні дії суб'єктів трудових відносин спрямовані на досягнення конкретного результата, який є позитивним за своїми наслідками і може бути визначеним в якості юридичного поступка. Юридичні проступки впливають на виникнення правових наслідків незалежно від того чи усвідомлював суб'єкт трудових відносин їх правове значення, бажав чи навпаки, настання правових наслідків. Правомірні поступки у сфері праці пов'язані як правило 3 виробництвом і споживанням матеріальних благ. Правомірними $є$ дії зі сторонни власника або уповноваженої ним посадової особи (органу) на забезпечення безпечних і нешкідливих умов праці працівника на робочому місці (ст. 153 КЗпП України)

Під юридично значимим результатом Л.А. Луць пропонує розуміт дії, що здійснюються 3 метою настання юридичних наслідків [5] правомірних або неправомірних. Вчинення юридичних актів зі сторони суб'єктів суспільних відносин як вважають М.В. Цвік, О.В. Петришин, Л.В. Авраменко та інші $є$ цілеспрямованою дією результати якої впливають на створення, зміну чи припинення відносин [6].

Для юридичних актів у сфері регулювання трудових та інших пов'язаних 3 ними відносин відносяться Закони України, Укази Президента України, постанови Верховної Ради України, постанови та розпорядження Кабінету Міністрів України, чинне законодавство України про працю та її охорону, накази та іні нормативно-правові акти, що регулюють трудові відносини. Дискусійним за змістом $€$ намагання авторів проекту трудового Кодексу України (№ 1658) віднести до основних прав роботодавця (п.8, ст.24)-право приймати нормативні акти.

Цікавою з приводу визнання в якості юридичного факту- події є думка І.Л.Самсіна, який вважає, що податкові закони як і Конституційні норми набувають чинності один раз і саме тому їх слід вважати юридичними фактом [7].

Юридичні акти в окремих випадках можуть поділятися на односторонні та двосторонні. Односторонні юридичні акти у сорері трудових відносин передбачають настання юридично значимих наслідків незалежно від волі інших осіб (наприклад, хвороба або смерть працівника судове рішення про поновлення працівника на роботі та інше)

Двосторонні юридичні акти вимагають наявності угоди між фізичними чи юридичними особами. Важливим при цьому $є$ те, що воля суб'єктів трудових відносин повинна мати закріплення (фікцію) в одному юридичному акті, 3 однаковими юридичними наслідками (наприклад, положення колективного договору поширюються на всіх працівників підприємства, установи, організації незалежно від того, чи є вони членами професійної спілки, і є обов'язковими як для власника або уповноваженого ним органу, так і для працівників підприємства, установи, організації - ст.18 КЗпП України).

До правомірних юридичних фактів відносяться юридичні вчинки сутністю яких $€$ правомірні дії, з якими норми трудового права пов'язують юридичні наслідки незалежно від направлення волі суб'єктів трудових відносин. Так, відповідно до ст. 253 КЗпП України особи, які працюють за трудовим договором (контрактом) підлягають загальнообов'язковому державному соціальному страхуванню. 
Неправомірними (деліктними, протиправними) діями як вважають О.В. Зайчук, Н.М. Оніщенко є дії, які не узгодженні з вимогами правових норм та порушують правові приписи [8]. Слід зауважити, що неправомірною є також бездіяльність, коли суб'єкти трудових та інших пов'язаних з ними відносин не реалізують своїх повноважень або не виконують трудових обов'язків.

Під час оцінки неправомірних дій працівника слушним є запитання про те, чому трудове правопорушення стає юридичним фактом? Ми вважаємо, що слід у першу чергу відрізняти негативні юридичні наслідки від неправомірних (протиправних) дій, вчинених суб'єктом правопорушення.

Неправомірні дії не мають позитивних наслідків, тому що суб'єкт правопорушення їх не передбачав і намагався умисно чи необережно їх досягнути. Так, протиправним за діями і наслідками є самовільне введення в експлуатацію нових і реконструйованих об'єктів виробничого та соціальнокультурного призначення (ст. 155 КЗпП України).

Протиправна поведінка суб'єктів трудових відносин $є$ найбільш характерною зовнішньою ознакою порушення законодавства про працю, яку слід вважати багатовекторним і різноплановим явищем реальної дійсності.

Протиправна поведінка суб'єкта трудових відносин передбачає як дію так і бездіяльність мають усвідомлений характер і спрямовані як правило, на досягнення корисливої мети. Протиправні дії суб'єкта трудового правопорушення можуть мати агресивний характер, що посилює небезпеку їх вчинення та можливий не лише шкідливий, але й суспільно небезпечний результат. Для прикладу, це стосується не лише порушень у додержанні трудової і технологічної дисципліни (ст. 139 КЗпП України), але й при порушенні вимог щодо охорони праці при проектуванні, будівництві (виготовленні) та реконструкції підприємства, об'єктів і засобів виробництва (ст. 154 КЗпП України), при введенні в експлуатацію підприємств, які не відповідають вимогам охорони праці (ст.155 КЗпП України), при передачі у виробництво зразків машин та інших засобів виробництва, впровадження нових технологій, що не відповідають вимогам охорони праці (ст. 156 КЗПП України).

Протиправна поведінка суб'єкта трудових відносин повинна мати причинний зв'язок між дією та бездіяльністю та наставщими необережними і шкідливими наслідками. За формою прояву причинний зв'язок між протиправною дією чи бездіяльністю і наставшим неправомірним результатом може бути як прямим так і опосередкованим. 3 філософських позицій причина служить для позначення необхідного зв'язку предметів і явищ матеріального світу, який полягає в утворенні або порушенні одними предметами і явищами (причинами) інших.

Діалектичний підхід у розгляді причинних зв'язків передбачає взаємодію між причинами і наслідками, які впливають одне на одного [9] Правове розуміння причинного зв'язку означає наявність необхідного зв'язку між явищами, під час якого одне явище(причина), призводить до появи іншого явища(результату) [10], тобто існує взаємозв'язок між предметами і явищами, що утворюється на основі передавання дії від одного предмета або явища до іншого [11].

Відсутність причинного зв'язку між протиправними діями чи бездіяльністю і неправомірним результатом буде свідчити про відсутність негативного юридично-значимого факта. 


\title{
Список використаних джерел:
}

1. Пасічна, І. О. (2012). Проблеми визначення поняття юридичних фактів у податковому праві. Держава та регіони, Серія: Право, (1). 187-192.

2. Марченко, Н. М. (2014). Теория государства и права. Москва: ТК Велби, Изд-во Проспект.

3. Марченко, М. Н. \& Дерябина, Е. М. (2004). Правоведение. Москва: ТК Велби. Изд-во Проспект.

4. Бабаева, В. К. (Ред.). (2003). Теория государства и права. Москва: Юристь.

5. Луць, Л. А. (2008). Загальна теорія держави та права. Київ: Атіка.

6. Цвік, М. В., Петришин, О. В., Авраменко, Л. В. та ін. (2011). Загальна теорія держави і права. Харків: Право.

7. Самсін, І. Л. (2014). Податкове зобов'язання в механізмі фінансово- правового регулювання (методологічний аспект). Автореферат дисертації на здобуття наукового ступеня доктора юридичних наук. Харків.

8. Зайчук, О. В. \& Оніщенко, Н. М. (Ред.). (2008). Загальна теорія держави і права. Основні поняття категорії прав, конструкції та наукові концепиії. Київ: Юрінком Інтер.

9. ПОЛЮС-ь. (1968). Український радянський енциклопедичний словник (T. 1-3 . Т 1.). Київ: Радян. енцикл. АН УРСР.

10. Сухарева, А. Я., Зорькина, В. Д. \& Крутских, В. Е. (Ред.). (1997). Большой юридический словарь. Москва: Инфра-М.

11. Петрушенко, В. (2009). Тлумачний словник основних фрілософських термінів. Львів: Видавво Національного ун-ту «Львівська політехніка».

\section{ПРОБЛЕМНІ АСПЕКТИ ДОТРИМАННЯ НОТАРІАЛЬНОЇ ТАЄМНИЦІ}

\author{
Шостак Юлія Олександрівна \\ студентка 4-го курсу \\ Дніпровський національний університет імені Олеся Гончара
}

Науковий керівник: Щербина Є.M канд. юрид. наук, доцент кафедри цивільного, трудового та господарського права Дніпровський національний університет імені Олеся Гончара

УКРАÏHA

Збереження нотаріальної таємниці нотаріусами $€$ важливою гарантією дотримання прав фрізичних та юридичних осіб, які звертаються за професійною допомогою. Однак, сучасна юридична доктрина містить не достатньо багато наукових праць в яких би досліджувались проблемні аспекти дотримання нотаріальної таємниці.

Ст. 8 Закону України «Про нотаріат» визначає, що нотаріальна таємниця це сукупність відомостей, отриманих під час вчинення нотаріальної дії або звернення до нотаріуса заінтересованої особи, в тому числі про особу, її майно, особисті майнові та немайнові права і обов'язки тощо [1]. При здійсненні юридичних дій нотаріусом безпосередньо стають відомо багато фрактів приватного життя людини, без знання яких неможливо здійснення ним своїх професійних повноважень. Людина змушена надати документи, в яких 
можуть міститися відомості, що становлять лікарську таємницю або банківську, або просто розголошення яких було б небажане. Однак, стверджувати про те, що на сьогоднішній день не трапляються випадки розголошення нотаріальної таємниці неможна, оскільки поки що існують деякі фактори, які можуть створювати умови для такого правопорушення.

В Україні фрактично відсутній законодавчо визначений порядок притягнення до відповідальності за розголошення нотаріальної таємниці. Диспозиція ч. 4 ст. 8 Закону побудована без конкретного посилання на відповідні нормативні акти. Отже за розголошення нотаріальної таємниці наступає лише відповідальність на підставі самого закону «Про нотаріат». При цьому найсуворішим покаранням для особи, яка вчинила такі дії, може стати лише позбавлення права на зайняття нотаріальною діяльністю. На думку Вислоцької Т.Ю це є абсолютно не відповідним ступеню суспільної небезпеки діяння, тим шкідливим наслідкам, які можуть наступити для потерпілого [4].

Крім того, через недосконалу правову регламентацію порушення нотаріальної таємниці може відбуватися у кримінальному процесі. Зокрема у ст. 65 КПК зазначено, що не можуть бути допитані як свідки нотаріуси 3 приводу того, що їм довірено чи стало відомо при здійсненні професійної діяльності, якщо вони не звільнені від обов'язку зберігати нотаріальну таємницю [2]. Однак статті 8 ЗУ «Про нотаріат» передбачає, що обов'язок дотримання нотаріальної таємниці поширюється також на осіб, яким про вчинені нотаріальні дії стало відомо у зв'язку з виконанням ними службових обов'язків чи іншої роботи, на осіб, залучених для вчинення нотаріальних дій у якості свідків, та на інших осіб, яким стали відомі відомості, що становлять предмет нотаріальної таємниці [1]. Але про інших осіб на яких поширюється обов'язок зберігати нотаріальну таємницю нічого не зазначено.

Крім того, дотриманню нотаріальної таємниці мають також сприяти умови праці нотаріуса. Вимоги до робочого місця (контори) приватного нотаріуса визначені у Положенні про вимоги до робочого місця (контори) приватного нотаріуса та здійснення контролю за організацією нотаріальної діяльності, затвердженому наказом Міністерства юстиції України від 23.03.2011 № 888/5. В цьому Положенні передбачено достатньо широкий перелік вимог, відповідність яким сприятиме дотриманню нотаріальної таємниці. Нажаль, поки що не можна говорити про таку детальну регламентацію вимог щодо робочих місць державних нотаріусів. Цьому можна знайти пояснення, оскільки облаштування нотаріальної контори приватного нотаріуса відбувається за його кошти, а державної нотаріальної контори - за кошти держави. Для забезпечення такими ж самими умовами робочі місця державних нотаріусів необхідно виділяти великі кошти, звичайно що в умовах дефіциту державного бюджету це досить складно. Якщо забезпечення власним кабінетом усих державних нотаріусів виглядає можливим, то навряд чи це стосується забезпечення металевими дверима, металевими ґратами на вікнах, вимог щодо стін та площі кабінету та ін. Через це, належне збереження нотаріальної таємниці саме в державних нотаріальних конторах ставиться під сумнів.

Найбільш спірними у судовій практиці сьогодні $€$ питання, пов'язані із винятками, що зумовлюють можливість нотаріуса розголошувати таємницю через виконання покладених на нього законом обов'язків щодо надання довідок про вчинену нотаріальну дію суб'єктам, визначеним у ст. 8 Закону. Довідки про вчинені нотаріальні дії та копії документів, що зберігаються у 
нотаріуса, видаються лише фізичним та юридичним особам, за дорученням яких або щодо яких вчинялися нотаріальні дії. У разі смерті особи чи визнання її померлою такі довідки видаються спадкоємцям померлого. У разі визнання особи безвісно відсутньою опікун, призначений для охорони майна безвісно відсутнього, має право отримувати довідки про вчиненні нотаріальні дії, якщо це необхідно для збереження майна, над яким встановлена опіка. Як виняток, такі довідки та інформація можуть бути видані на обґрунтовану письмову вимогу суду, прокуратури, органів, що здійснюють оперативно-розшукову діяльність, органів досудового розслідування [3].

На підставі вищезаначеного можна підсумувати, що принцип нотаріальної таємниці має досить вагоме значення, який поширює свою дію не лише на нотаріусів, але й на інших осіб яким стала відома нотаріальна таємниця під час виконання службових обов'язків. Але на жаль на законодавчому рівні це питання має деякі суперечності та недоліки, які потрібно усунути для того щоб гарантувати права особам, які звертаються за професійною допомогою.

\section{Список використаних джерел:}

1. Про нотаріат (Закон України), № 3425-XII. (2018). Вилучено 3:https://zakon.rada.gov.ua/laws/show/1105-14.

2. Кримінально-процесуальний кодекс, № 4651-VI, (2019) Вилучено 3 https://zakon.rada.gov.ua/laws/show/4651-17.

3. Баранкова, В. (2017). Поняття та межі нотаріальної таємниці. Мала енциклопедія нотаріуса, 4 (94), 192-219. Вилучено з http://yurradnik.com.ua/wp-content/uploads/2017/09/Barankova.pdf.

4. Вислоцька, Т. Ю. (2016). Про охорону нотаріальної таємниці в кримінальному процесі. Науковий вісник Херсонського державного університету (Т.2), (3), 59-62. Вилучено 3 http://www.lj.kherson.ua/2016/pravo03/part_2/15.pdf.

\section{РОЗВИТОК КОНСТИТУЦІОНАЛІЗМУ В УКРАЇНІ}

Левкович Інна Володимирівна

здобувач вищої освіти юридичного фракультету Дніпровський національний університет імені Олеся Гончара

Науковий керівник: Чукаєва Вероніка Олександрівна канд. іст. наук, доцент, доцент кафедри теорії держави та права, конституційного права та державного управління Дніпровський національний університет імені Олеся Гончара УKPÄ̈HA

Розвиток конституціоналізму становить важливу роль у формуванні конституційного, міжнародного, національного правового регулювання. Шлях розвитку конституціоналізму бере свій початок від давньогрецьких конституцій, які існували ще за декілька століть до нашої ери. Український конституціоналізм бере свій початок, ще до створення своєї першої Конституції (Конституція Пилипа Орлика 5 квітня 1710р.). Конституція як основний Закон держави містить основоположні засадничі норми, які визначають основи 
побудови, фуннціонування конституціоналізму певної держави. Конституція не регламентує порядку реалізації тих чи інших ії положень. У теорії конституційного права конституціоналізм виступає одним із центральних, якщо не найголовнішим правовим феноменом. Дискусії щодо визначення поняття конституціоналізму, його основних ознак, моменту його виникнення як правового явища, тенденцій функціонування та розвитку продовжуються в конституційно-правовій науці, досі залишаються актуальними. Питання конституціоналізму доволі широко досліджували такі українські та зарубіжні науковці, як Дж. Білліас, Дж. Волдрон, Т. Гінсбург, Де Сікейра, А. Р. Крусян, Ч. Маклвейн, М. П. Орзіх, М. В. Савчин, О. В. Скрипнюк, П. Б. Стецюк, С. В. Шевчук та інші [1].

Конституціоналізм визначає природу конституції через призму соціальних цінностей, щодо яких склався у суспільстві консенсус. Виражаючи правові засади політичної єдності, взаємозв'язку інститутів громадянського суспільства та публічної влади, конституційний лад визначає основні параметри особистої свободи індивіда та раціональні засади організації публічної влади. Така система правління визначає гарантії прав людини і основоположних свобод та організації публічної влади на засадах її поділу та обмеження свавільного застосування закону [2].

В.М. Шаповал розглядає конституціоналізм передусім як політико-правову ідеологію, інтелектуальні узагальнення, притаманні певному етапу історичного розвитку, а також як державне правління, обмежене за змістом конституції. В іншій праці він стверджує, що явище конституціоналізму має складний, багатовимірний характер, та виділяє два головні «вектори» його визначення як режиму, у якому функціонують держава та її інститути, що водночас $є$ режимом взаємостосунків держави і людини, а також як правової (конституційної) ідеології, яка відображає і водночас прогнозує розвиток відповідної нормотворчості і нормозастосування.

М. В. Савчин зазначає, що конституціоналізм $є$ багатовимірним політикоправовим феноменом і складною структурою та досліджує його як соціальне явище, що відображає еволюцію поглядів, ідей, доктрин про природу конституції та політичної практики втілення таких ідей в життя. На думку П. Б. Стецюка, конституціоналізм можна розглядати у широкому (політикоправовому, політологічному) та вузькому (юридичному) значеннях. Причому у широкому розумінні конституціоналізм є ідейно-політичною доктриною, ідейнополітичним рухом та державно-правовою практикою, а в юридичному державне правління, обмежене конституцією; вчення про конституцію як основний закон держави, закон, який визначає відносини держави i суспільства; політичні системи, в основі яких лежать конституційні методи правління. А. Р. Крусян виокремлює три головні підходи до визначення конституціоналізму: політичний, філософрсько-історичний та юридичний. У політичному контексті конституціоналізм - це «скарбниця національної ідейнополітичної думки і державно-правової практики, що спрямована на конституційну регламентацію державного устрою, політичного режиму, прав і свобод людини, взаємовідносин людини, громадян, суспільства і держави» [3].

Основним здобутком козацької гетьманщини виділяють пакти та конституції, які були написані видатним гетьманом Пилипом Орликом, 
Г. Герциком та А. Войнаровським, які в науковій доктрині іменуються першою Конституцією України. Іншими здобутками виділяють "Пакти та Конституції законів та вольностей Війська Запорізького" , які були прийнять в формі угоди між гетьманом та Військом Запорізьким. Подальший розвиток конституціоналізму охоплює середину та другу половину XIX ст.. Тут , зокрема, виокремлюють Григорія Андрузького 3 його «Начерком Конституції Республіки» (1848-1850рр.), Михайла Драгоманова з його фундаментальною роботою «Вольний Союз - Вільна Спілка» (1884р.). Наступний період сягає кінця XIX ст. - початку XX ст.. В ці часи були прийняті акти Центральної Ради та Української Народної Республіки, а саме III та IV Універсали. Ці документи закріпили основні демократичні принципи, з яких виділяють: розподіл влади, громадянські права і свободи, інтереси національних меншин, самоврядування, децентралізацію влади, парламентаризм, скасування смертної кари та ін [4]. Після проголошення незалежності України в 1991 році, починається етап розбудови Україною свого власного політико-правового простору, відповідно до якого в 1996 році приймається Конституція України, яка ставить розвиток Українського конституціоналізму на нову ступінь розвитку, відповідно до якої закріплюються основні права, свободи та обов'язки кожного громадянина, встановлюються такі принципи: принцип демократії, соціальної держави, правової держави, принципи гуманізму, гласності, розподілу влади, свободи, рівності та ряд інших. Прийняття Основного Закону України остаточно завершує процес становлення України як суверенної держави. Основний здобуток конституціоналізму, на сьогодні, закріплений в ст. 5 Конституції України (далі - Конституції), який визначає, що єдиним джерелом влади в Україні $є$ народ [4]. Таким чином, основні здобутки конституціоналізму, відповідно до ст. 1 Конституції, що Україна є суверенна, незалежна, демократична, соціальна, правова держава.

Правовий механізм є основним у системі забезпечення конституціоналізації правового порядку, головною передумовою якої є правові приписи, що становлять її нормативну основу. Тому чим вони досконаліші, тим повніше втілюються в життя й тим вищий рівень законності. Якщо соціальні та психологічні чинники впливають на стан правопорядку опосередковано, то юридичні - безпосередньо визначають характер його конституціоналізації. У змістовому сенсі якість законодавства частко-во залежить від його відповідності закономірностям розвитку суспільства. 3 огляду на це в юридичних джерелах зауважується, що прийнятий нормативний акт має відповідати тим відносинам, на які спрямовується його регулятивна дія. Окрім цього, положення будь-яких нормативних актів мають відповідати потребам суспільства, зокрема щодо того, чи стосується це необхідності прийняття такого акта, визначення ефективності регулювання ним суспільних відносин без порушення їх гармонії і стабільності [5].

На ефективність конституціоналізації правового порядку неабияким чином впливає також розвиток норм неофіційної нормотворчості й тіньового права. Такі негативні явища, як тіньове право та неофіційна нормотворчість, особливо чітко проявляють себе в період зміни політико-правового режиму в сучасній Україні. Неофіційна нормотворчість становить велику соціальну небезпеку. На жаль, для сучасної Української держави характерна ситуація, 
коли в умовах послаблення авторитету законів і виникнення правового дисбалансу, за якого суспільство втрачає нормативні орієнтири, не спирається на конституційні принципи, норми моралі. Перевага в таких випадках часто надається вимогам деформованої правосвідомості й так само деформованій моральній орієнтації індивіда. Виходить, що в основі виникає й розвивається так звана неофіційна нормотворчість, тобто створення неофіційних правил поведінки, якими керуються певні групи населення. Передумовою цього процесу слугують розчарування в чинній нормативній системі, зневіра в неї. Таке явище, як тіньове право, - це негативний вияв юридичного плюралізму, специфічна форма неправа, небезпечний різновид негативного неофіційного права, що становить звід асоціальних приписів, символів, ритуалів, жаргону, за допомогою яких регламентуються всі етапи протиправної діяльності, утворюється тіньовий правопорядок [5].

Отже, поняття конституціоналізму є складним, комплексним та обширним. Воно позначає не тільки режим здійснення державної влади (способи правління), а його зміст, певну якість буття держави (конституційної) та її взаємовідносини із громадянським суспільством. Чинники які впливають на процес конституціоналізації правового порядку, забезпечують нормальне функціонування й поступальний розвиток суспільства та держави, так зумовлюють необхідність повного й чіткого законодавчого регулювання суспільних відносин, послідовну реалізацію нормативно-правових актів, зокрема конституції. Головним у цьому процесі $€$ власне юридичний механізм конституціоналізації правового порядку. Українській Конституції притаманна певна мінливість, яка характеризується недотриманням деяких її положень, невиконанням чиновниками своїх прав та обов'язків, посягання на права і свободи людини та громадянина. Тобто подальша реформа Конституції, яка закріпить новий етап конституціоналізму має уособлювати в собі статистичну складову, яка, як показує Міжнародний досвід, має певні свої переваги.

\section{Список використаних джерел:}

1. Забокрицький, І. І. (2015). Основні аспекти сучасного розуміння конституціоналізму. Вісник Національного університету: "Львівська політехніка". Юридичні науки, (876), 53-60.

2. Савчин, М. В. (2018). Історія та основі ідеї конституціоналізму. Лекція, (30).

3. Бориславська, О. М. (2015). Сутність конституціоналізму: конституціоналізм як ідеологія, доктрина та практика обмеженого правління. Вісник Львівського університету. Серія юридична, (61), 247-256.

4. Панченко, А. О. (2017). Тенденції сучасного конституціоналізму в Україні. Державо - та правотворчі традиції українського народу (до 150-річчя М.С. Грушевського): зб. тез доповідей III Всеукр. наук.-практ. конференції (с. 253-254), 23 листопада 2016 р. Вінниця: «Нілан-ЛТД».

5. Подорожна, Т. С. (2016). Юридичні чинники конституціоналізації правового порядку. Актуальні проблеми вітчизняної юриспруденції, (2), 26-30. 


\section{СИСТЕМНІСТЬ ТА НОРМАТИВНІСТЬ У ПРАВІ: ДІАЛЕКТИКА ВЗАЄМОДії}

Андрощук Анастасія Русланівна

здобувач вищої освіти юридичного фракультету

Національний університет біоресурсів і природокористування України

Науковий керівник: Козін Сергій Миколайович

канд. юрид. наук, асистент кафедри теорії та історії держави і права

Національний університет біоресурсів і природокористування України

УКРАÏHA

Приблизно з середини XX століття стало очевидним, що оточуючий нас світ має системний характер: будь-який матеріальний чи нематеріальний об'єкт $€$ або системою, або елементом якоїсь системи чи ії частини. Вивчення штучних систем приводить до висновку про те, що всі вони мають стійку тенденцію до ускладнення, до надбання системних властивостей у сучасному розумінні цього терміна, до розширення міжсистемних зв'язків, перестають бути ізольовані, замкнутими, роблять усе більш очевидний вплив одна на одну і на природу складових їх елементів [1].

У цьому контексті досить актуальним $є$ питання про розгляд права як системи. Право як система - це методологічний рівень для зазначених категорій, оскільки вони, поряд з іншими теоретичними конструкціями, входять в одну зі складових права як певної сфери буття та мислення людини юриспруденцію [2].

Як стверджує відомий російський науковець М. Н. Марченко, право передусім являється сукупністю, точніше системою, норм, яка не є випадковим набором будь- яких норм, а суворо вивіреною, упорядкованою системою в цілому визначених правил поведінки, яка має бути внутрішньо єдиною і непротирічною [3].

У більшості наукових досліджень, де вживається поняття «системність як ознака права», мається на увазі тільки можливість впорядкувати правові норми певним чином, згрупувати їх в ті чи інші стійкі об'єднання. 3 розвитком протягом останніх десятиліть системології вітчизняна теорія права перейняла деякі елементи ії наукового апарату, звичайними стали і твердження про переваги системного підходу в дослідженні права.

Виділяючи нормативність як особливу властивість і розглядаючи іï як визначальну, найбільш загальну в складі всього комплексу всіх властивостей права, необхідно спочатку, як зазначалося вище, зауважити, що право загалом може бути охарактеризоване як «система норм», тобто загальних правил, зразків, моделей поведінки, які поширюються на всі випадки подібних відносин і відповідно до яких має здійснюватися поведінка всіма особами, що потрапили в нормативно регламентовану ситуацію, тобто стали суб'єктами-учасниками правовідносин.

На системності права як його особливій та незаперечній властивості наголошує П. М. Рабінович, стверджуючи, що «право $є$ системним, багаторівневим, багатогранним френоменом...» [4]. 
Тут особливо слід зазначити з приводу неприпустимості змішування понять «система права» і «правова система», оскільки вони не тотожні. У першому випадку мова йде про внутрішню будову права, а в другому - про правову організацію всього суспільства, сукупність усіх юридичних інститутів і засобів, що існують і фрункціонують у державі. Таким чином, «правова система» об'ємніша за змістом категорія. Система права виступає лише складовою частиною, однією з елементів правової системи [5].

Право є сукупністю створюваних і охоронюваних державою норм [6]. Але це не випадкове, не хаотичне нагромадження їх, а строго узгоджена i взаємозалежна система, в якій норми групуються в певному порядку на основі загальних принципів. Право постає перед нами як складне системне ієрархічне явище, що існує на основі процесів інтеграції та диференціації [7].

Як зазначає П. П. Богуцький, системність $€$ однією $з$ найважливіших властивостей права, проте, поряд з цим зазначає, що право водночас розглядають як унікальну соціально-нормативну систему, що власне визначає його форму і зміст. За таких обставин використання в епістемології права системного підходу є необхідним [8].

Поряд $з$ цим, як зазначає К. Г. Волинка, поняття нормативності права як важливої і необхідної його ознаки, вказуючи, що нормативність виявляє сенс і саме призначення права. Нормативністю права до суспільного життя вносяться істотні елементи єдності, рівності, принципової однаковості - право виступає як загальний масштаб, міра (регулятор) поведінки людей. За допомогою норм право регулює різні суспільні відносини, слугує знаряддям втілення в життя політики держави, засобом організації ії різнобічної управлінської та іншої діяльності. У нормативності $є$ одна істотна риса: право виражається в нормативних узагальненнях (загальні дозволяння, загальні заборони, загальні зобов'язання), які встановлюють межі досягнутої свободи, межі між свободою і несвободою на певному ступені суспільного прогресу [9].

Інакше кажучи, як системність, так і нормативність права виступають його основними i в той же час взаємопов'язаними та взаємозалежними характеристиками. Оскільки право $є$ саме «системою норм», які чітко впорядковані між собою, а не хаотичним їх розташуванням у чинному законодавстві.

Про діалектичні взаємозв'язки цих властивостей права стверджував ще М. Н. Кулажніков, кажучи, що в широкому розумінні право $є$ системою загальнообов'язкових юридичних норм, які являються необхідним специфічним державним регулятором найбільш важливих суспільних відносин [10].

У сучасній літературі досі існує хибна, на нашу думку, точка зору, за якою системність ототожнюється 3 нормативністю права, котра обґрунтовується тим, що нормативність $€$ системою права, яка складається тільки з самих норм (правил поведінки), іншими словами, нормативність розуміється як система норм [1].

Таким чином, системність права є його невід'ємною особливістю, а також специфічною закономірною рисою не тільки самого права, але й правової нормативності, оскільки визначаючи право у нормативному змісті, необхідно упорядкувати наявні у ньому правові приписи, інакше це порушить існуючий у юридичній науці порядок і, як правило, призведе до хаосу правових норм, що унеможливить їх правильне застосування. У такому випадку право перестає 
бути для суспільства необхідністю, тому зникають об'єктивні потреби у його існуванні. На сьогодні в Україні одним із найважливіших та найнагальніших завдань $€$ відновлення та зміцнення системності права, її узгодженості 3 правовою нормативністю, оскільки невідповідність положень нормативноправових актів розриває системоутворюючі зв'язки між правовими нормами.

\title{
Список використаних джерел:
}

1. Костылев, В. М. (2002). Проблемы системного и фоормально-логического характера права (автореф. .... канд. юрид. наук). Уфра, Росія.

2. Оборотов, Ю. М., Завальнюк, В. В. \& Дудченко, В. В. (2012). Актуальні грані загальнотеоретичної юриспруденції. Одеса: Фенікс.

3. Марченко, М. Н. (2014). Общая теория государства и права. Академический курс, (Т. 1-3). Москва: НОРМА.

4. Рабінович, П. М. (2008). Загальносоціальна («природна») правова система: поняття і структура. Вісник Академії правових наук України, (4), 6-7.

5. Лившиц, Р. 3. (1982). Система права и перспективы ее развития. Советское государство и право, (6), 96.

6. Рабец, А. М. (2002). Интеграция и дифференциация в праве. Труды Московской государственной юридической академии, (9), 54-57.

7. Алексеев, С. С. (1999). Право: азбука-теория-философия: Опыт комплексного исследования. Москва: Статут.

8. Богуцький, П. П. (2013). Системний підхід і криза раціоналізму в юриспруденції. Розвиток методології сучасної юриспруденції, 12 квітня 2013 р. Одеса, Україна.

9. Мамченко, М. В. (2007). Дуалізм природного і позитивного права як синтез цілей правової системи (автореф. .... канд. юрид. наук). Київ, Україна.

10. Макаров, О. В. (1995). Соотношение права и государства. Государство и право, (5), 17.

\section{СПІВРОБІТНИЦТВО ДЕРЖАВ У БОРОТЬБІ І3 ЗЛОЧИННІСТЮ}

\begin{abstract}
Перерва Анастасія Олександрівна
студент юридичного факультету Дніпровський національний університету ім. О. Гончара

Науковий керівник: Ведькал Валентина Андріївна канд. іст. наук, доцент, доцент кафедри європейського та міжнародного права Дніпровський національний університету ім. О. Гончара УКРAÏHA

На сучасному етапі розвиток суспільства та нових технологій породжує нові форми загроз. Злочинність становить одну з основних загроз національній безпеці держави. На жаль, така негативна діяльність часто має місце не лише у самій державі, де нею займаються правоохоронні органи, вона також переходить межі країн, тому з'являється необхідність налагодження взаємовідносин між державами та міжнародними організаціями, а також необхідність міжнародного співробітництва саме у боротьбі зі злочинністю.
\end{abstract}


Боротьба зі злочинністю належить до пріоритетних напрямів міжнародного співробітництва. Тому зрозуміло, що за всю історію співробітництва суб'єктів міжнародного права у протидії злочинності було накопичено досить великий обсяг міжнародно-правових норм, принципів та механізмів попередження, протидії, припинення та розслідування міжнародних правопорушень, що торкаються даної проблеми.

Загальновизнаним центром з координації та розвитку міжнародних зв'язків $€$ Організація Об'єднаних Націй $(\mathrm{OOH})$. Вона розробляє і ухвалює спеціальні міжнародні документи, де визначаються поняття злочинів міжнародного характеру, злочинів проти людства, тероризм, піратство та ін. Крім Генеральної Асамблеї ООН цим питанням займаються спеціальні конгреси 3 попередження злочинності і поводження з правопорушниками, які, в свою чергу, розробляють спільну стратегію і тактику запобігання злочинності та заходи з її мінімізації.

Аналіз основних напрямків співробітництва держав у боротьбі зі злочинністю, а саме, обмін інформацією між державами про вчинені злочини та злочинців, визначення кола загально небезпечних діянь, що потребують спільних зусиль щодо їх припинення, надання допомоги в розшуку злочинців які перебувають на території держави та видача їх зацікавленим суб'єктам міжнародного права, а також укладання міжнародних договорів про боротьбу з окремими видами міжнародних злочинних діянь, дає можливість автору визначити мету та завдання співробітництва.

Метою міжнародного співробітництва держав у боротьбі зі злочинністю є:

а) узгодження кваліфрікації міжнародних злочинів;

б) надання взаємної правової допомоги по кримінальних справах, включаючи видачу злочинця;

в) координації зусиль і заходів для запобігання і припинення злочинів;

г) боротьба з окремими категоріями найбільш небезпечних злочинів;

д) спільне вирішення окремих тактичних завдань розслідування (розшук злочинців, що переховуються, крадених речей і т. д.);

е) боротьба з транснаціональними злочинами в окремих сфрерах діяльності (на транспорті, у сфері зовнішньої торгівлі);

ж) забезпечення невідворотності покарання.

Що ж стосується задач міжнародного співробітництва у боротьбі зі злочинністю, то ними є:

- взаємодія на міждержавному рівні;

- утворення міжнародних координаційних органів;

- взаємодія на рівні окремих відомств, що беруть участь у боротьбі 3 міжнародною і транснаціональною злочинністю;

- взаємодія між правоохоронними органами сусідніх регіонів двох і більше країн.

В силу необхідності протидії міжнародним злочинам держави вступають у багатосторонні міжнародні угоди, які визначають взаємні права і обов'язки учасників відносно протидії злочинності.

Відповідно до п. 4 ст. 2 Статуту ООН: "усі члени $\mathrm{OOH}$ утримуються в їх міжнародних відносинах від погрози силою або її застосування...”. Даний обов'язок, тобто незастосування сили, поширюється на всі держави і $€$ основою для співробітництва між ними в різних сфрерах, також й у сфері боротьби зі злочинністю. 3 цього випливає , що співробітництво між державами 
у сфері боротьби зі злочинністю має ґрунтуватися на добровільній основі, без будь-якого примусу чи погрози.

Висновки. Отже, проблема боротьби зі злочинністю, яка сьогодні все частіше набуває міжнародних масштабів, становить загрозу як усьому світовому товариству, так і окремим державам, основним правам і свободам людини. Мова йде про підвищення ії суспільної небезпеки, заподіюваної шкоди. Тому вирішальну роль у вирішенні даної проблеми має відігравати міжнародне співробітництво держав у боротьбі зі злочинністю. Співробітництво має бути спрямоване на розробку і координацію заходів щодо попередження, розкриття злочинів і поводження з правопорушниками, а також вироблення комплексних цілей і завдань з мінімізації транснаціональних і внутрішньодержавних протиправних діянь.

Слід також зауважити, що боротьба зі злочинністю - це справа внутрішньої компетенції держави. Виходячи з цього, можна говорити про те, що держава вправі самостійно укладати договори та угоди про боротьбу з окремими видами злочинів, вступати у міжнародні організації, що займаються проблемами зі злочинністю тощо. Держави також є вільними у виборі форм участі в роботі міжнародних конференцій, семінарів, присвячених боротьбі зі злочинністю та при застосуванні норм міжнародного права ніхто не може втручатися у внутрішні справи інших держав. Під час укладання договорів, спрямованих проти злочинності, усі процесуальні питання вирішуються тільки згідно з внутрішнім законодавством держави.

\title{
Список використаних джерел:
}

1. Теліпко, В.Е.(2010). Міжнародне публічне право. К.: Центр учбової літератури. Вилучено 3 http://library.nlu.edu.ua/POLN_TEXT/CUL/26_2-Mizhnarodne_publichne_pravo-Telipko2010.pdf

2. Cтатут Організації Об'єднаних Націй і Статут Міжнародного Суду, поточна редакція. Редакція від 16.09.2005. Вилучено з https://zakon.rada.gov.ua/laws/show/995_010

3. Про організаційно-правові основи боротьби з організованою злочинністю (Закон України), № 3341-XI. (1993). Вилучено з https://zakon.rada.gov.ua/laws/show/3341-12

\section{СПОСОБИ БОРОТЬБИ 3 АБСЕНТЕЇЗМОМ В ЄВРОПЕЙСЬКИХ КРАЇНАХ}

\begin{abstract}
Шостак Юлія Олександрівна
студентка 4-го курсу

Дніпровський національний університет імені Олеся Гончара
\end{abstract}

Науковий керівник: Литвин Олена Петрівна

канд. юрид. наук, доцент

Дніпровський національний університет імені Олеся Гончара

УКРАЇНА

Вибори є основною формою участі населення в політиці та в управлінні державою. Громадяни таким чином обирають напрямок суспільного розвитку i тих, кому вони довірять цей напрямок реалізовувати. Однак впродовж останніх років не лише в Україні а й багатьох країнах Європи набуває поширеності таке 
негативне явище як абсентеїзм, тобто ухилення виборців від участі в голосуванні під час виборів. Проблема абсентеїзму на сьогоднішній день дуже гостро стоїть у всьому світі, чим і обумовлюється актуальність даної теми.

Перші дослідження даної проблематики почалися ще на початку $\mathrm{XX}$ століття. Серед вітчизняних вчених, які розривали дану тему в своїх роботах варто назвати: Гаврилюка Д.Ю., Красинського В.В., Сидоренка О.В., Стукаленко В.А.

Більшість вчених розглядають абсентеїзм як явище, що властиве кожній політичні системі, побудованої на принципах демократії і свободи. Однак зниження політичної активності громадян на виборах може призвести до питання легітимності нової влади. Зрозуміло, що політичний діяч чи партія, які не отримав підтримки більшої частини населення не може розглядатися носіями законної влади. Крім того, у деяких випадках через масову неявку виборців, необхідно проводити повторні вибори, що в свої чергу призводить до значних матеріальних витрат.

Останнім часом у більшості демократичних країн світу спостерігається зменшення електоральної активності населення. Можна назвати дуже багато причин, які спонукають до виникнення цього явища. Однак основною причиною можна назвати те, що люди не бачать свого впливу на життя, а тому ігнорують вибори [3]. Слід зазначити, що в багатьох країнах вироблені певні механізми боротьби з таким явищем, зокрема наприклад законодавчо встановлена обов'язковість виборця прийняти участь в голосуванні.

У своєму дослідженні Толкач А.Н. наведе приклад таких країн як Греція (тюремне ув'язнення на строк від місяця до одного року); Бельгія (залежно від кількості проігнорованих виборів, передбачені різні за розмірами штрафи від 50 до 125 євро. Після четвертого випадку ігнорування виборів - громадянин позбавляється виборчих прав на 10 років та втрачає право перебувати на державній службі); Люксембург (перша неучасть в голосуванні - штраф 80 євро, а друга - 240 євро); Італія, Ірландія (участь громадян у виборах визнається їхнім обов'язком, за невиконання якого протягом п'яти років прізвища порушників вносяться до спеціальних списків, які виставляються на загальний огляд) [4].

Використання таких механізм як обов'язкова участь у виборах $є$ досить суперечливим положенням, оскільки в деякій мірі такий примус може порушувати принцип свободи виборів, що $\epsilon$ вагомим складовим демократичності держави. В юридичній літературі немає єдиного підходу щодо тлумачення змісту цього принципу. Так одні вчені стверджують, що принцип вільних виборів означає, що в процесі їх організації і проведення повністю виключається будь-який примус щодо участі або неучасті як у виборах в цілому, так і власне у самій процедурі голосування [2]. В такому випадку дійсно, в певній мірі санкції за неучасть у виборах порушують вищезгаданий принцип. Примусова явка не тотожна ефективному голосуванню. Застосовуючи до громадян примусові заходи за неучасть у голосуванні неможливо домогтися від них дійсної зацікавленості в житті держави.

За іншим підходом, принцип свободи виборів означає, що виборцям повинні бути забезпечені належні умови для вільного формування своєї волі та її вільного виявлення при голосуванні. В цьому разі обов'язкову участь у 
виборах можна розглядати як положення, що не суперечить принципу свободи виборів.

Крім запровадження введення в практичну дію конституційної норми обов'язкового голосування у своїй дисертаційній роботі Гаврилюк Д.Ю. досліджуючи абсентеїзм виділяє також інші засоби, що можуть сприяти для подолання абсентеїзму. Зокрема, зниження рівня виборчого порогу явки (Азербайджан, США); запровадження і гарантування ініціативного способу формування виборчих списків (США, Люксембург); запровадження механізму фракультативного типу голосування; гарантування можливостей волевиявлення за довіреністю та поштою (Франція, Великобританія) [1].

Окрему увагу до себе звертає останній пункт, а саме, можливість голосування поштою. Досить схожою є практика використання механізму Інтернет-голосування, як це проводиться в Швейцарії, Естонії, Бразилії. Для подолання абсентеїзму в України досвід зарубіжних країн з використання таких нетрадиційних способів голосування може послужити прикладом, однак для того щоб впроваджувати такі новації в нас необхідно розробити певні механізми які б не давали можливості маніпуляцій та фальсифрікацій під час голосування.

Отже, підсумовуючи вищезазначене, можна сказати, що політичний абсентеїзм зумовлений різними причинами, однак призводе він до єдиного наслідку - зниження легітимності влади. Тому для подолання цього держава має приймати якісь дії, що матимуть комплексний характер, зокрема розроблювати якісь програми для підвищення правової культури виборців для того щоб вони розуміли важливість їх голосу, що він має значення і може змінити життя на краще.

\section{Список використаних джерел:}

1. Гаврилюк, Д. Ю. (2015). Абсентеїзм як феномен електоральної культури в контексті демократизації українського суспільства (дис. ... канд. екон. наук). Київ, Україні. Вилучено $3 \mathrm{http}: / /$ enpuir.npu.edu.ua/handle/123456789/7137.

2. Ключковський, Ю. Б. (2018). Принципи виборчого права: доктринальне розуміння, стан та перспективи законодавчої реалізації в Україні. Вилучено з https://www.osce.org/uk/projectcoordinator-in-ukraine/401765?download=true.

3. Стукаленко, В. А. (2014). Теоретичні аспекти абсентеїзму. Правова держава, (17), 15-20. Вилучено 3 http://nbuv.gov.ua/UJRN/Prav_2014_17_5.

4. Толкач, А. М. (2017). Абсентеїзм виборців: світовий досвід подолання та шляхи його реалізації в Україні. Розумовські зустрічі: збірник наукових праць, (4), 118-124. Вилучено 3 https://sivertraining.org.ua/wp-content/uploads/2017/12/Rozum-zbirnik_2017_Vol-

4_last.pdf\#page $=119$. 


\section{ТОРГІВЛЯ ЛЮДЬМИ: КРИМІНОГЕННІ ДЕТЕРМІНАНТИ ТА ЗАХОДИ ПРОТИДІЇ В УКРАЇНІ}

\section{НАУКОВО-ДОСЛІДНА ГРУПА:}

Томчук Інна Олександрівна

канд. юрид. наук, викладач юридичних дисциплін

Галицький коледж імені В'ячеслава Чорновола

Денисовський Михайло Дмитрович канд. юрид. наук, викладач юридичних дисциплін

Галицький коледж імені В'ячеслава Чорновола

Томчук Ірина Олександрівна здобувач вищої освіти Інституту міжнародних відносин та Інституту філології Київський національний університет імені Тараса Шевченка

УКРАÏHA

На сьогоднішній день $з$ метою отримання прибутків здійснюється чимало злочинів в нашій державі, особливу небезпеку серед яких становить торгівля людьми, яку слід вважати однією з найжорстокіших форм порушення основних прав і свобод людини. Протягом останнього десятиліття ця злочинність набула особливої актуальності не лише в Україні, але й у всьому світі. Так, за даними ООН «торгівлею людьми охоплені усі без винятку країни світу, або ж в якості країн походження, транзиту чи призначення жертв» [1].

Питанням протидії торгівлі людьми раніше вже приділяло увагу багато науковців, серед яких: П.П. Андрушко, В.С. Батиргареєва, Ю.В. Баулін, В.І. Борисов, В.О. Глушков, В.В. Голіна, І.М. Даньшин, В.О. Іващенко, В.А. Козак, К.Б. Левченко, Я.Г. Лизогуб, О.В. Наден, А.М. Орлеан, В. М. Підгородинський, А.С. Політова, О.В. Святун та багатьох інших. Проте, в сучасних умовах, комплексне дослідження криміногенних детермінант торгівлі людьми і водночас заходів протидії цим злочинам залишається і надалі актуальним. «Дані злочини постійно еволюціонують услід за прагненнями злочинців отримати щонайвищі прибутки від експлуатації постраждалих та протистояти зусиллям правоохоронних органів з протидії їхній злочинній діяльності», - як вірно зазначають з цього приводу науковці М. О. Васильєва, В. В. Касько, А. М. Орлеан та О. В. Пустова [2].

Серед основних криміногенних детермінант, що сприяють поширенню торгівлі людьми можна виокремити наступні: складна економічна ситуація в країні та високий рівень безробіття; недосконалість кримінального законодавства щодо відповідальності за торгівлю людьми; недостатня обізнаність громадян щодо можливостей працевлаштування в інших країнах та своїх прав при цьому; багатообіцяюча реклама стосовно працевлаштування за кордоном в 3MI, натомість недостатньо повідомлень щодо самих фрактів торгівлі людьми і розкритих «схем» такої злочинності; впевненість злочинців, які здійснюють торгівлю людьми, у тому, що їх не буде викрито та покарано, адже в більшості випадків ці дії завершуються за кордоном; недосконалі практичні навички працівників правоохоронних органів щодо розкриття даної злочинності та недостатня співпраця з іншими державами та міжнародними 
організаціями стосовно спільного розкриття злочинів, пов'язаних із торгівлею людьми.

Погоджуємося $з$ думкою В. Чігера стосовно того, що жертвами торгівлі людьми, найчастіше за все, стають ті особи, які, бажаючи за будь-яку ціну уникнути важких умов життя, хочуть швидко без зайвих зусиль заробити кошти. «Саме тому, вони необачно погоджуються залишити Батьківщину, вірячи безпідставним обіцянкам підвищення рівня своїх доходів. У результаті, багато хто з них потрапляє у важкі ситуації, стає жертвами безжалісної фрізичної й моральної експлуатації, змушені виконувати важку, неоплачувану роботу вище своїх сил, а також зазнає побиття, погроз і принижень» [3].

У боротьбі з таким злочином, як торгівля людьми винятково важливе значення має кримінальне законодавство, удосконалення якого неможливе без врахування положень міжнародних договорів, що стосуються протидії торгівлі людьми та вивчення зарубіжного досвіду в цьому питанні. Слід зауважити, що підписання міжнародних угод та, зокрема, Протоколу про попередження та запобігання торгівлі людьми, що доповнює Конвенцію ООН проти транснаціональної організованої злочинності [4], а також Конвенції Ради Європи про протидію торгівлі людьми [5] стимулює країни до закріплення у національних законодавствах єдиного уніфікованого визначення торгівлі людьми.

У зв'язку з цим до статті 149 КК України були запропоновані і внесені численні зміни на основі прийняття Верховною Радою України Закону України «Про внесення зміни до статті 149 Кримінального кодексу України щодо приведення у відповідність з міжнародними стандартами» від 06.09.2018 р.[6], які набрали чинності 06.10.2018 р. Таким чином, стаття 149 КК України має вже назву «Торгівля людьми» та передбачає кримінальну відповідальність за вчинення таких дій: «Торгівля людиною, а так само вербування, переміщення, переховування, передача або одержання людини, вчинені 3 метою експлуатації, 3 використанням примусу, викрадення, обману, шантажу, матеріальної чи іншої залежності потерпілого, його уразливого стану або підкупу третьої особи, яка контролює потерпілого, для отримання згоди на його експлуатацію. Покарання за такі дії передбачене у виді позбавленням волі на строк від трьох до восьми років.

Слід згадати, що відповідно до ч. 3 примітки до ст. 149 КК України, кримінальна відповідальність за вищевказані дії в ч. 1 ст. 149 КК, вчинені щодо малолітнього або неповнолітнього, настає незалежно від зазначених способів. Як видно з диспозиції даної статті кількість можливих способів вчинення цього злочину, порівняно 3 попередньою редакцією, значно розширилася: 3 використанням примусу, викрадення, матеріальної чи іншої залежності потерпілого або підкупу третьої особи, яка контролює потерпілого.

Щодо кваліфікуючих ознак за ч. 2 ст. 149 КК України, то вони залишилися практично незмінними: вчинені щодо неповнолітнього або щодо кількох осіб, або повторно, або за попередньою змовою групою осіб, або службовою особою з використанням службового становища, або поєднані з насильством, яке не є небезпечним для життя чи здоров'я потерпілого чи його близьких, або з погрозою застосування такого насильства. Покарання за такі дії залишилося без змін: позбавлення волі на строк від п'яти до дванадцяти років 3 конфіскацією майна або без такої.

Стосовно особливо кваліфікуючих ознак даного злочину (ч. 3 ст. 149 КК України), то ними є наступні: вчинені щодо неповнолітнього його батьками, 
усиновителями, опікунами чи піклувальниками, або вчинені щодо малолітнього, або організованою групою, або поєднані 3 насильством, небезпечним для життя або здоров'я потерпілого чи його близьких, або з погрозою застосування такого насильства, або якщо вони спричинили тяжкі наслідки, тобто їх кількість збільшилася. Зокрема, законодавець додав вчинення таких дій вчинені щодо неповнолітнього його батьками, усиновителями, опікунами чи піклувальниками. I такі дії також без змін караються позбавленням волі на строк від восьми до п'ятнадцяти років 3 конфіскацією майна або без такої.

Незважаючи на нещодавні зміни до ст. 149 КК України, на нашу думку, законодавство України у цій сфрері потребує й надалі істотного корегування відповідно до сучасних умов, внесення відповідних змін з метою підвищення кримінально-правової протидії даній злочинності, адже масштаби та обсяги работоргівлі в нашій країні продовжують залишатись загрозливими.

Очевидно, що торгівля людьми може носити, як транснаціональний характер, так і здійснюватися всередині країни. Кодекси ряду зарубіжних країн передбачають більш сувору відповідальність у разі переміщення особи за межі держави з метою її подальшої експлуатації. КК України не виділяє таких дій як кваліфікуючу ознаку злочину, тому і відповідальність $€$ абсолютно однакова, що, на нашу думку, є неприпустимим.

Таким чином, для прикладу, Кримінальним кодексом Республіки Білорусь, відповідальність за торгівлю людьми передбачена в Главі 22 «Злочини проти особистої свободи, честі та гідності» статтею 181 «Торгівля людьми» [7]. Такі дії караються позбавленням волі на строк від трьох до семи років 3 конфіскацією майна». Якщо ж іде мова про торгівлю людьми із вивезенням за межі держави (п. 8 ч. 2 ст. 181 КК Республіки Білорусь), тоді відповідальність відповідно у виді позбавлення волі на строк від семи до дванадцяти років 3 конфіскацією майна. Вважаємо доцільним запозичення для КК України такого досвіду кримінально-правової протидії торгівлі людьми як в Республіці Білорусь, та доповнення ч. 2 ст. 149 КК України ще однією кваліфікуючою ознакою «з вивезенням особи за межі державного кордону України», адже враховуючи транснаціональність даного злочину таке діяння має вищий ступінь суспільної небезпеки, тому і покарання повинно бути більш суворим. Аналогічна кваліфікуюча ознака «з переміщенням потерпілого через Державний кордон Російської Федерації або з незаконним утриманням його за кордоном» передбачена і за КК Російської Федерації (п. г ч. 2 ст. 127-1) [8].

Щодо інших кваліфрікуючих ознак торгівлі людьми за ч. 2 ст. 127-1 КК Російської Федерації, які не передбачені в чинній редакції ч. 2 ст. 149 КК України, то ними $є$ наступні: з використанням підроблених документів, а так само 3 вилученням, приховуванням або знищенням документів, що засвідчують особу потерпілого (п. «д» ч. 2 ст. 127-1); з метою вилучення у потерпілого органів чи тканин (п. «ж» ч. 2 ст. 127-1); і) щодо жінки, яка завідомо для винного перебуває у стані вагітності (п. «і» ч. 2 ст. 127-1). Позитивним також вбачається наявність в примітці 1 даної норми, на відміну від КК України і Республіки Білорусь, спеціального виду обов'язкового звільнення від кримінальної відповідальності за наявності таких умов: 1) особа вчинила вперше діяння, передбачені ч. 1 або пунктом «а» ч. 2 цієї статті; 2) особа добровільно звільнила потерпілого; 3) особа сприяла розкриттю вчиненого злочину; в діях особи не міститься інший склад злочину. Вважаємо такий підхід стосовно кримінально-правової протидії торгівлі людьми вартий уваги, тим 
більше він буде відповідати вищезгаданому Протоколу [4]. Внесення таких змін, вважаємо, також сприятиме мінімізації такого виду злочинної діяльності в Україні, адже покарання за вищезгадані дії буде більш суворим.

У Щорічному звіті Держдепартаменту США «Торгівля людьми 2017» є також певні зауваження стосовно того, що торговці людьми в Україні продовжують уникати серйозних покарань у виді тюремного ув'язнення, тобто позбавлення волі на певний строк [9], що також $є$ надзвичайно важливим фактором, який перешкоджає протидії даній злочинності.

Підсумовуючи вищевикладене, доцільним вбачається здійснення таких заходів протидії торгівлі людьми в Україні:

1. Посилити контроль за діяльністю юридичних осіб, які мають ліцензії на посередництво у працевлаштуванні на роботу за кордоном та пропонують сумнівні послуги знайомства та працевлаштування, а також вимоги щодо відповідальності підприємств, установ, організацій усіх форм власності, що організовують виїзди та працевлаштування громадян за кордоном, у зв'язку з нещасними випадками. Позитивний вплив, вважаємо, справить також контроль Інтернету працівниками правоохоронних органів з метою виявлення такого роду діяльності та відповідних пропозицій.

2. Покращити інформованість, обізнаність населення про фракти торгівлі людьми та можливість уникнення таких ситуацій: держава повинна фінансувати та організовувати інформаційні кампанії у $3 \mathrm{Ml} 3$ метою попередження даних злочинів, а також висвітлення питань стосовно запобігання торгівлі людьми у навчальних програмах, відповідних виховних заходах для дітей та учнівської молоді.

3. Систематично сприяти працевлаштуванню населення шляхом збільшення кількості робочих місць та забезпечити належний рівень заробітної плати.

4. Підвищувати професійний рівень працівників органів державної влади, які здійснюють повноваження у сфері протидії торгівлі людьми шляхом фінансування їх стажування в країнах, які мають успішний досвід боротьби 3 даною злочинністю та проведення тренінгів, спрямованих на розвиток практичних навичок у відповідній сфері.

5. Збільшити рівень ресурсного та фрінансового забезпечення для проведення розслідувань і захисту осіб, які постраждали від торгівлі людьми.

6. Систематично здійснювати співпрацю з правоохоронними органами зарубіжних держав, міжнародними організаціями, що виконують різні функції у сфері протидії торгівлі людьми та відповідними соціальними службами, що здійснюють надання допомоги особам, які постраждали від торгівлі людьми.

7. Вдосконалити кримінальне законодавство, яке передбачає відповідальність за торгівлю людьми шляхом внесення наступних змін до ст. 149 КК України:

- посилити кримінальну відповідальність у разі вивезення особи за межі України з метою її подальшої експлуатації шляхом доповнення ч. 2 ст. 149 КК України кваліфікуючою ознакою «з вивезенням особи за межі державного кордону України»;

- з метою збільшення рівня розкриття даної злочинності слід запровадити спеціальний вид звільнення від кримінальної відповідальності за наявності певних умов, доповнивши ст. 149 КК України частиною четвертою такого змісту: «Звільняється від кримінальної відповідальності особа, яка вчинила вперше діяння, передбачені ч. 1 цієї статті, добровільно звільнила потерпілого 
та сприяла розкриттю вчиненого злочину».

Вважаємо, що виконання запропонованих заходів дозволить мінімізувати дану злочинність на території нашої держави.

1. ООН. Торговля людьми: тяжелье фокты. Извлечено из https://www.unodc.org/documents/blueheart/factsheet_russian.pdf.

2. Васильєва, М. О., Касько, В. В., Орлеан, А. М. \& Пустова, О. В. (2012). Україна як країна призначення для торгівлі людьми. Матеріали для практичного використання працівниками прикордонної служби, правоохоронних органів та суддями. Київ: Фенікс.

3. Чігер, В. (2019). Кримінальна відповідальність за торгівлю людьми. Підприємництво, госnодарство і право, 5, 266-269. https://doi.org/10.32849/2663-5313/2019.5.49.

4. Протокол про попередження і припинення торгівлі людьми, особливо жінками і дітьми, i покарання за неї, що доповнює Конвенцію Організації Об'єднаних Націй проти транснаціональної організованої злочинності підписаний від імені України в м. НьюЙорку (2001). Ратифікований ВРУ 04.02.2004. Набрання чинності для України 21.05.2004. Вилучено 3 https://zakon.rada.gov.ua/laws/show/995_791.

5. Конвенція проти транснаціональної організованої злочинності. (2000). Ратифікована ВРу 04.02.2004. Набрала чинності для України 21.05.2004. Вилучено 3 https://zakon.rada.gov.ua/laws/show/995_789.

6. Про внесення зміни до статmі 149 Кримінального кодексу України щодо приведення у відповідність з міжнародними стандартами (Закон України). № 2539-VIII. (2018). Вилучено 3 https://zakon.rada.gov.ua/laws/show/2539-19\#n5.

7. Уголовный кодекс Республики Беларусь. № 275-3. (1999). Извлечено из http://etalonline.by/document/?regnum=HK9900275.

8. Уголовный кодекс Российской Федерации. $N$ 63-Ф3. (1996). Извлечено из http://pravo.gov.ru/proxy/ips/?docbody\&nd=102041891.

9. U.S. Department of State.Trafficking in Persons Report (2017). Вилучено 3 https://www.state.gov/j/tip/rls/tiprpt/2017/index.htm.

\title{
ТРАНСФОРМАЦІЯ ІНСТИТУТУ ДЕРЖАВНОЇ РЕЄСТРАЦІЇ РЕЧОВИХ ПРАВ НА НЕРУХОМЕ МАЙНО В УКРАЇНІ В УМОВАХ СЬОГОДЕННЯ
}

\begin{abstract}
Навчально-науковий інститут права та психології Національного університету «Львівська політехніка»
\end{abstract}

Німак Марія Орестівна

Андрусів Ірина Тарасівна

студентка 2 курсу магістратури

Навчально-науковий інститут права та психологї Національного університету «Львівська політехніка»

УКРӒ̈HA

Відносини власності $€$ найважливішими суспільними відносинами, врегульованими нормами права. Право власності регулюється та гарантується законодавчими актами України, а відтак володіє особливим захистом та надійною процедурою реєстрації. Незважаючи на те, що Україна 
перебуває на перехідному етапі розбудови єдиної процедури державної реєстрації речових прав на нерухоме майно та їх обтяжень (далі - державної реєстрації прав), рефооми, які відбуваються останнім часом, сприяють виробленню однозначних правил проведення державної реєстрації.

Однак, як справедливо зауважує А. С. Кеча, фактично до 1 січня 2013 року діюча на той час система органів, які здійснювали державну реєстрацію прав, була заплутаною та недосконалою: а) речові права на земельні ділянки та їх окремі обтяження реєструвалися територіальними органами земельних ресурсів у Державному реєстрі земель у складі ДЗК (Державного земельного кадастру), держателем якого було Державне агентство земельних ресурсів України; б) права на будинки, споруди, квартири та об'єкти незавершеного будівництва реєструвалися у БТІ (Комунальне підприємство «Бюро технічної інвентаризації та експертної оцінки»), а інформація містилася в Реєстрі прав власності на нерухоме майно, держателем якого було Міністерство юстиції України; в) реєстрація правочинів, обтяження нерухомого майна, у тому числі земель, будинків, споруд, квартир, іпотека реєструвалися в Державному реєстрі правочинів, Державному реєстрі іпотек та в Єдиному реєстрі заборон відчуження об'єктів нерухомого майна нотаріусами та реєстраторами Державного підприємства «ннформаційний центр», держателем яких було Міністерство юстиції України [1]. Відтак реєстрація здійснювалась різними органами та посадовими особами та у різних реєстрах.

Має рацію І.І. Завальна, констатуючи, що особливість реєстрації до 2013 року полягала в тому, що кожен з наведених суб'єктів не мав доступу до реєстрів, які ведуть інші суб'єкти, і при цьому витяги з одних реєстрів $€$ необхідними документами для проведення реєстраційних дій в інших, що створювало потребу користувача послугами самостійно звертатися до різних органів за їх отриманням. Іншими словами, для того, щоб досягти мету у вигляді набуття права власності на нерухомість особі в деяких випадках необхідно було звертатися за отриманням декількох адміністративних послуг до різних суб'єктів [2].

Як відомо, із набранням чинності 1 січня 2013 року Закону України «Про державну реєстрацію речових прав на нерухоме майно та їх обтяжень» в новій редакції [3] було запроваджено новий порядок реєстрації речових прав на нерухоме майно, а також реєстрації їх обтяжень. Нововведення полягало у тому, щоб об'єднати в одному реєстрі інформацію про всі існуючі речові права та обтяження стосовно об'єкта нерухомості, як-от: право власності, право користування (оренди), заставу, іпотеку чи арешт тощо.

Відтак Реєстр прав власності на нерухоме майно, Єдиний реєстр заборон відчуження об'єктів нерухомого майна, Державний реєстр іпотек та Державний реєстр обтяжень рухомого майна стали складовими частинами Державного реєстру речових прав на нерухоме майно та їх обтяжень, а відтак реєстратор, який отримує інфрормацію з Державного реєстру речових прав, одночасно має можливість отримати відомості і з цих реєстрів.

Вважаємо, що в основі таких реформацій став принцип «єдиного вікна». На думку профессора Н. Гончарук, суть зазначеного принципу полягає у тому, що приватна особа подає заяву та при потребі необхідний мінімум документів, а збір довідок, погодження тощо має здійснюватися всередині адміністрації 
(всередині адміністративного органу та між адміністративними органами), а не покладатися на особу [4].

Станом на сьогодні, відомості з Реєстрів використовуються державним реєстратором для: встановлення наявності чи відсутності записів про обтяження речових прав на нерухоме майно (обтяжень податковою заставою), під час проведення державної реєстрації прав з метою їх перенесення до Державного реєстру прав, під час розгляду заяв про взяття на облік безхазяйного нерухомого майна, заяв/запитів на отримання інформації 3 Державного реєстру прав; для встановлення наявності (відсутності) записів про державну реєстрацію права власності або іншого речового права на нерухоме майно під час проведення державної реєстрації прав та під час розгляду заяв про взяття на облік безхазяйного нерухомого майна, заяв /запитів на отримання інформації з Державного реєстру прав [5].

Однак вищенаведені трансформації призвели до деяких суперечностей в частині дублювання інформації про об'єкт нерухомого майна та суб'єктів права власності. На практиці існують випадки, коли особа, яка бажає зареєструвати право власності на майно, отримує відмову державного реєстратора, у зв'язку з тим, що під час здійснення процедури державної реєстрації прав виникає невідповідність особи - власника майна.

3 огляду на це, Порядком ведення Державного реєстру речових прав на нерухоме майно, затвердженим Постановою Кабінету Міністрів України від 26 жовтня 2011 року №1141, було передбачено проставлення відміток про погашення запису у «старих» реєстрах. Відповідно до п. 45 цього Порядку якщо державну реєстрацію прав проведено до 1 січня 2013 р., то при теперішній їх реєстрації в архівній складовій частині Державного реєстру прав, після внесення до Державного реєстру прав відомостей, передбачених Порядком, державний реєстратор проставляє у Реєстрі прав власності на нерухоме майно, Єдиному реєстрі заборон відчуження об'єктів нерухомого майна та/або Державному реєстрі іпотек відмітку про погашення такого запису [6].

Однак, якщо у Реєстрі прав власності на нерухоме майно власникам належало майно на праві спільної сумісної або спільної часткової власності, то така відмітка проставляється виключно щодо тієї особи, стосовно прав якої здійснюється реєстрація.

Також вищевказані правила застосовуються у тому разі, коли така державна реєстрація вже була здійснена в Державному реєстрі прав, але до появи норми про необхідність проставлення відмітки про погашення, то під час проведення наступних реєстраційних дій щодо того чи іншого об'єкта нерухомого майна, але тільки за умови його належної ідентифікації у відповідних реєстрах, або у випадку якщо реєстраційні дії не здійснюються за заявою про внесення змін до записів Державного реєстру прав, яку може подати особа (ії спадкоємці (правонаступники)), щодо права якої в Реєстрі прав власності на нерухоме майно не проставлено відмітку про погашення.

Однак, така ситуація все ще призводить до негативних наслідків, а саме до можливих способів шахрайства. Зважаючи на випадки вчинення незаконних реєстраційних дій шляхом несанкціонованого доступу до Державного реєстру, Міністерство юстиції України затвердило Наказом від 18 липня 2019 року № 
2185/5 заходи щодо посилення збереження та захисту даних Державного реєстру речових прав на нерухоме майно, Єдиного державного реєстру юридичних осіб, фрізичних осіб - підприємців та громадських формувань. Так, Державному підприємству «Національні інформаційні системи» доручено провести верифікацію та актуалізацію відомостей про державних реєстраторів, а також нотаріусів; видати особам, які успішно пройшли верифрікацію, нові паролі доступу та водночас скасувати діючі; анулювати доступ користувачам, які не пройшли верифікацію або своєчасно не звернулись щодо її проведення [7].

Висновки. Завдяки сформованій новій системі реєстрації прав, вдалось уникнути багатьох суперечностей, які виникали до 2013 року. Так, було позбавлено бюрократичних перешкод процедури реєстрації, скорочено часовий проміжок реєстрації прав та обтяжень, певною мірою усунено випадки так званої «подвійної реєстрації». Разом з тим, існує ще чимало невирішених проблем, що виникають при здійсненні реєстрації, які потребують негайного усунення з метою якнайефективнішого захисту прав та свобод громадян.

\section{Список використаних джерел:}

1. Кеча, А. С. (2016). Адміністративно-правове регулювання державної реєстрації речових прав на нерухоме майно (автореф. дис. ... кандидата юрид. наук). Одеса, Україна.

2. Завальна, І. І. (2013). Принцип «єдиного вікна» та його застосування в процедурі державної реєстрації речових прав на нерухоме майно в Україні. Наукові записки Львівського університету бізнесу та права, (10), 143-148.

3. Про державну реєстрацію речових прав на нерухоме майно та їх обтяжень (Закон України). № 1952-IV. (2004). Вилучено з https://zakon.rada.gov.ua/laws/show/1952-15.

4. Гончарук, Н. (2011). Організаційно-правові аспекти надання адміністративних послуг в Україні. Публічне управління: теорія та практика, (1 (5)), 26-32.

5. Про затвердження Порядку використання даних Реєстру прав власності на нерухоме майно, Єдиного реєстру заборон відчуження об'єктів нерухомого майна, Державного реєстру іпотек та Державного реєстру обтяжень рухомого майна (Наказ Міністерства юстиції України). № 1844/5. (2012). Вилучено з https://zakon.rada.gov.ua/laws/show/z2102-12.

6. Про затвердження Порядку ведення Державного реєстру речових прав на нерухоме майно (Постанова Кабінету Міністрів України). № 1141. (2011). Вилучено 3 https://zakon.rada.gov.ua/laws/show/1141-2011-п.

7. Про заходи щодо посилення збереження та захисту даних Державного реєстру речових прав на нерухоме майно, Єдиного державного реєстру юридичних осіб, фрізичних осіб підприємців та громадських формувань (Наказ Міністерства юстиції України). № 2185/5. (2019). Вилучено з https://zakon.rada.gov.ua/laws/show/z0790-19. 


\section{SECTION 14. HISTORY}

DOI 10.36074/25.10.2019.v3.14

\section{ПРОЦЕС АНТИРАДЯНСЬКОЇ АКТИВНОСТІ В УКРАЇНСЬКОМУ СЕЛІ НА 3ЛАМІ 1920-1930-Х РОКІВ ЯК СЕГМЕНТ НАРОДНОГО ОПОРУ СТАЛІНСЬКІЙ МОДЕРНІЗАЦІЇ СУСПІЛЬСТВА}

\section{Мотуз Валерія Костянтинівна}

канд. іст. наук, ст. викладач кафедри антропології

та спеціальних галузей історичної науки

Черкаський національний університет імені Богдана Хмельницького

УКРАЇНA

Одним із найскладніших етапів у боротьбі українського селянства за свої права став радянський період історії України, а точніше - кінець 1920-х початок 1930-х рр. - доба запровадження сталінських методів господарювання в українському селі, коли його мешканцям насильницьким шляхом нав'язувалась адміністративно-командна система із засадами директивного планування.

Такий соціально-економічний експеримент, під красномовною назвою «суцільна колективізація», став одним зі стовпів соціалістичного будівництва в Україні. Йому було притаманне радикальне руйнування одвічного укладу та стилю селянського життя через примусове переведення українського селянства 3 традиційних, індивідуальних методів виробництва сільськогосподарської продукції до колективних [2].

Стрижневе завдання відповідного заходу партійно-радянська верхівка вбачала у зміні традиційного світогляду селянина, насамперед вихолощенні у нього сутності власника. Зруйнувавши національну ментальність створити ідеальний, на її думку, тип «нової людини» - радянський [4].

Для утвердження нового режиму в українському селі радянські владні структури застосовували різні способи напоумлення непокірних. Серед яких фрізичне знищення «політично неблагонадійних», депортація сотень тисяч сільських мешканців, перш за все представників заможних верств [3].

Радянський державний терор відносно потенційно небезпечних жителів села, ставши невід'ємною складовою модернізації сільськогосподарського виробництва в Україні в кінці 1920-х рр., викликав гострий спротив селянства [1].

Його прояв та поступове наростання невдоволення діями радянської влади в українському селі бере свій початок з грудня 1929 р. Відтоді по всій підрадянській Україні один за одним почали спалахувати локальні виступи, що вже само по собі демонструвало здатність українського селянства чинити відсіч насильницьким діям радянської влади [4].

Антирадянський спротив українського села досягає свого апогею в перші роки «великого перелому». Так, масштабність, глибина активного та пасивного 
опору його мешканців колективізаційним заходам радянської влади призвели до того, що практично вся територія України з січня 1930 р. до жовтня 1931 р. була охоплена масовим селянськими протестами [5]. Наприклад, значного розмаху, хоч і на короткий період, але все ж таки набула ліквідація місцевих органів радянської влади у низці сільських населених пунктів [6].

Наявність селянського повстанського руху в підрадянській Україні на рубежі 1920-х - 1930-х рр. засвідчила існування ще й збройного спротиву політиці суцільної колективізації. Проте, останній не набув широкого розповсюджена внаслідок вилучення ДПУ основної маси зброї, що залишалася на руках у населення після Першої світової війни та національновизвольних змагань 1917-1920 рр. [7], а також розташування на території України достатньої кількості військових гарнізонів, готових у будь-який момент придушити «спалах бандитизму» [4].

Стосовно активного та пасивного характеру антиколгоспного руху в Україні у кінці 1920-х - на початку 1930-х рр. більшість сучасних дослідників одностайні в думці, що перший вид опору проявився в таких формах як збройні виступи та «баб'ячі бунти», діяльність невеликих повстанських загонів, підпали, спільні виступи декількох сіл і районів, масові мирні мітинги та демонстрації, саботаж, бойкотування та зрив різноманітних заходів радянської влади, антиколгоспна агітація, надсилання листів-звернень до вищих органів влади УСРР та СРСР, цькування представників місцевих органів радянської влади тощо [6]. Другий, набув значно більшого поширення в Україні, ставши візитівкою українського села періоду суцільної колективізації. Йому було притаманне винайдення різноманітних способів уникнення оподаткування та розкуркулення [4]. До останнього варто віднести знищення власної сільськогосподарської техніки та реманенту, продаж чи забій худоби та птиці, приховування зерна, втеча з села та інше [3].

Попри те, що вимоги протестуючих здебільшого були соціально-економічно орієнтованими, прослідковується і їх політична складова. Наприклад, антирадянські активісти нерідко діяли під гаслами визволення України 3 більшовицьких лещат. Відповідний перебіг подій став черговим масовим актом прояву боротьби українського народу за власне право національнодержавного самовизначення після Української національно-демократичної революції 1917-1921 рр. [1].

Такий запеклий опір став чітким посилом партійно-радянському керівництву щодо масового неприйняття українським селянством обраного ним курсу соціально-економічної політики. Однак, більш небезпечним сигналом для нього виявився сумнів посіяний серед населення України щодо дієздатності радянської влади, її спроможності контролювати ситуацію в державі. Як згодом з'ясується, виходом зі складної політичної ситуації для сталінської команди став штучно організований нею голод в Україні, пік якого припав на $1932-1933$ р. [4;6].

Висновки. 3 огляду на вищевикладене, авторка прийшла до наступних висновків: антирадянський протест українського селянства на зламі 1920-х 1930-х рр. став його відповіддю на радикальні трансформації запроваджені партійно-радянською верхівкою задля руйнування традиційного укладу селянського життя. Прагнення останньої перетворити українського селянина в 
«пролетаря на землі» зустріло рішучу протидію під час підготовки та проведення нею суцільної колективізації першої хвилі. Селянській тактиці спротиву відповідного періоду були притаманні певні прояви елементів організованості та згуртованості, наявність гасел самостійності України, що перетворювали її на справжню селянську війну проти радянської влади.

\section{Список використаних джерел:}

1. Білокінь, С. (1999). Масовий терор як засіб державного управління в СРСР (1917-1941рр.): джерелознавче дослідження. Київ. 447 с.

2. Васильєв, В. (2010). Сталінська революція «згори» в Україні: насилля, протидія, результати. Історія України: Маловідомі імена, події, факти, (36), С. 73-88.

3. Вегет, М. (1999). Дорога в небуття: (Спогади про розкуркулення). Визвольний шля, 2. С. 223-234.

4. Веселова, О. М. (гол. ред.) Історія українського селянства: Нариси у 2-х т.: Т. 2. Київ: «Наукова думка», $654 \mathrm{c}$.

5. Кульчицький, С. В. (2003). Криза колгоспного ладу: 1930-1931рр. Український історичний журнал, 5. С. 5-25.

6. Кульчицький, С. В. (2004) Опір селянства суцільній колективізації. Український історичний журнал, 2. С. 31-50.

7. Чайковський, А. (1999). ОДПУ-НКВС і колективізація. Історія України, 10. С. 1-3. 


\section{SECTION 15. GEOGRAPHY}

\section{БІОКЛІМАТИЧНІ ПОКАЗНИКИ ПОЛТАВСЬКОЇ ОБЛАСТІ}

Рибчан Вікторія Сергіївна
учень 10-М класу
Полтавський обласний науковий ліцей-інтернат імені А.С. Макаренка

Науковий керівник: Глухота Віталій Олександрович

учитель II категорії

Полтавський обласний науковий ліцей-інтернат імені А.С. Макаренка

УКРАЇНA

Вивчення біокліматичних показників проводиться 3 точки зору комфортності погоди і клімату для організму здорової людини. Для виявлення особливостей найчастіше застосовують комплексні показники, які характеризують тепловий стан людини, оскільки клімат і погода впливають, насамперед, на термічний режим організму і його функціональна діяльність багато в чому залежить від умов теплообміну з навколишнім середовищем. Ці показники дозволяють оцінити кліматично-рекреаційні ресурси конкретних територій, визначити їхній рекреаційний потенціал.

До таких показників належать: нормально-еквівалентно-ефективні, біологічно-активні, радіаційно-еквівалентно-ефективні температури, показники суворості погоди тощо [1].

Нормальна ефективна температура за нормальною шкалою або нормально-еквівалентно-ефективна температура (НЕET). Цей показник дозволяє оцінити тепловідчуття людини, захищеної одягом стандартного типу для певного сезону, тобто вона враховує вплив теплозахистних властивостей одягу. Визначення тепловідчуття через НЕЕТ стосується лише тіньових просторів, де на людину не впливає пряма сонячна радіація.

Розраховується НЕЕТ за фрормулою Міссенарда [1].

de:

$$
\text { HEET }=37-\frac{37-t}{0.68-0.0014 \times f+\frac{1}{1.76+1.4 \times v^{0.75}}}-0.29 \times t \times\left(1-\frac{f}{100}\right),
$$

$t$ - температура повітря;

$v$ - швидкість вітру на рівні 1,5 м;

$f$ - відносна вологість.

Цінність еквівалентно-ефективної температури за нормальною шкалою як біокліматичного показника полягає в тому, що їі можна використовувати не лише при оцінці теплового навантаження, але і в умовах холоду, тобто залежно від сезону людина має різні теплові відчуття та теплове навантаження на організм, які можуть призвести як до теплового удару, (влітку) так і до обмороження (взимку).

Г. Хентшел запропонував класифікацію нормально еквівалентноефективних температур, яка по суті своїй $є$ класифікацією клімату з точки зору біометеорології людини [2]. 
Усі наведені індекси ефективних температур мають значний недолік - в них не враховується тепловідчуття людини за рахунок нагрівання тіла при надходженні сонячної радіації, що $є$ дуже важливим в літній період, таким чином їх використання має обмежуватися лише розрахунком тепловідчуття для людини, що перебуває на затінених територіях. Саме з метою мінімізації даних недоліків, була розроблена радіаційно-еквівалентно-ефективна температура, яка враховує вплив на тепловідчуття чотирьох метеорологічних елементів - температури та вологості повітря, швидкості вітру та сонячної радіації. Нами була використана фрормула за наближенням I. В. Бутьєвої [1].

$$
\text { PEET }=\text { HEET }+6,2^{\circ} \mathrm{C}
$$

Класифікація PEET характеризує можливості геліотерапії. Геліотерапія застосування сонячних променів з лікувальною і профілактичною метою.

Для геліотерапії хворих з певними формами захворювань розроблені оптимальні теплові умови, які характеризуються величиною PEET:

$P E E T=17-29^{\circ} \mathrm{C}-$ при гіпертонічній хворобі 1-ої стадії;

$P E E T \leq 26^{\circ} \mathrm{C}-$ хворим з ішемічною хворобою серця;

$P E E T \leq 29^{\circ} \mathrm{C}$ - при затяжній і хронічній пневмонії 1-ої стадії.

Сукупність одночасної дії $\mathrm{T}^{\circ} \mathrm{C}, \mathrm{f} \%, \mathrm{~V} \mathrm{~m} / \mathrm{c}$ та відбитої радіації Землі враховує так звана біологічно активна температура (БАТ) [1].

$$
\text { БАТ }=0,8^{\circ} \mathrm{PEET}+6
$$

Вплив температури і вологості повітря, температури і швидкості вітру на тепловідчуття людини можна виразити через показники дискомфорту.

Для оцінки суворості погоди - фактора, який обмежує перебування людини на відкритому повітрі і зумовлює потребу у відповідній одежі, розроблена достатньо велика кількість показників холодового впливу метеорологічних чинників на організм.

Одним 3 найбільш популярних методів оцінки суворості погоди $є$ метод Бодмана [1]. Ступінь суворості погоди в балах він пропонує визначати за наступною формулою.

de:

$$
S=(1-0.04 t)(1+0.272 v)
$$

$S-$ індекс суворості (бали);

$t$ - температура повітря, ${ }^{\circ} \mathrm{C}$;

$v$ - швидкість вітру, $\mathrm{m} / \mathrm{c}$.

Таблиця 1

Індекси характеристики зими

\begin{tabular}{|c|c|}
\hline $\boldsymbol{S}$ & Характеристика зими \\
\hline$<1.0$ & несувора, м'яка \\
\hline $1.0-2.0$ & мало сувора \\
\hline $2.1-3.0$ & помірно-сувора \\
\hline $3.1-4.0$ & Сувора \\
\hline $4.1-5.0$ & дуже сувора \\
\hline $5.1-6.0$ & жорстко сувора \\
\hline$>6.0$ & украй сувора \\
\hline
\end{tabular}

взято 3 [2]

Територія Полтавської області розташована в помірному поясі в атлантикоконтинентальній європейській області. Кліматичні умови i їх ресурси характеризуються сезонними змінами, впливом підстилаючої поверхні, 
місцевими особливостями природи. Формування кліматичних ресурсів відбувається безперервно внаслідок неперервного поступлення сонячної радіації і безперервності процесів теплообміну, волого обміну, атмосферної циркуляції та фракторів, пов'язаних з впливом характер земної поверхні [4].

Для аналізу впливу відповідних фракторів, нами було проаналізовано основні кліматичні характеристик за період 2008-2018 років на 5 метеостанціях області: Гадяча, Веселого Подолу, Кобеляк, Лубнів та Полтави [3].

На основі аналізу відповідних кліматичних показників нами було визначено ряд і біокліматичних показників області - нормально-еквівалентно-ефективні, біологічно-активні, радіаційно-еквівалентно-ефрективні температури, показники суворості погоди.

Нормально-еквівалентно-ефективні температури (HEET) були визначені за багаторічними показниками температури, вологості, та швидкості вітру, а також окремо для січня та липня місяців за 2008-2018 роки.

Показники HEET коливалися від $14,0^{\circ} \mathrm{C}$ в Гадячі до $14,7^{\circ} \mathrm{C}$ в Полтаві, що згідно з класифікації діапазону НЕЕТ означає комфортно, помірно тепло.

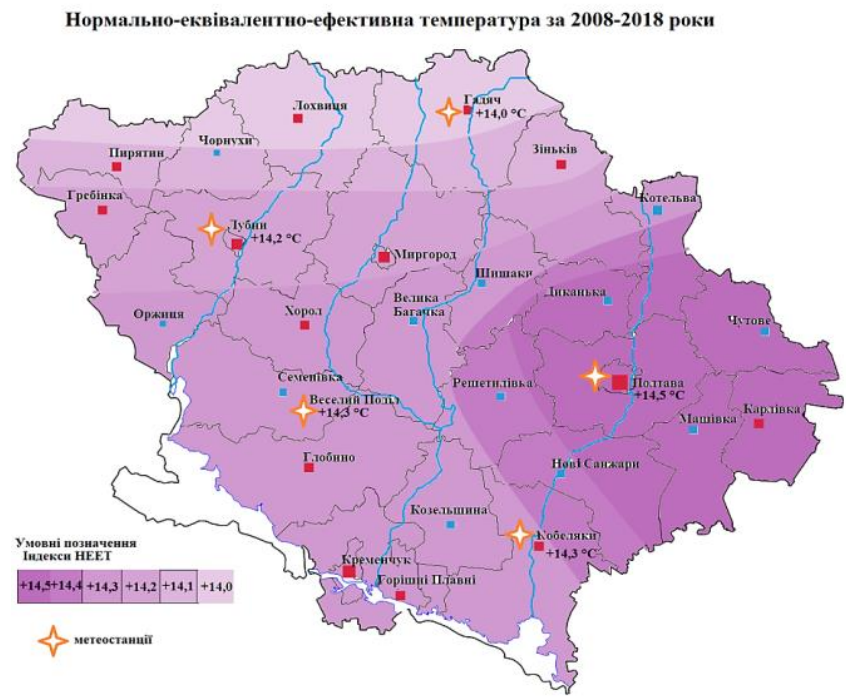

Рис. 1. Середньорічна нормально-еквівалентно-ефективна температура за даними 2008-2018 років

Для більш об'єктивного визначення НЕET, нами було проведено аналогічні розрахунки для липня та січня. Показники НЕET липня коливалися від $+16,3^{\circ} \mathrm{C}$ в Гадячі, до $+16,7^{\circ} \mathrm{C}$ в Кобеляках, що також згідно з класифікації діапазону HEET означає комфортно, помірно тепло. Показники HEET січня коливалися $4,0^{\circ} \mathrm{C}$ в Полтаві та Веселому Подолі до $-4,5^{\circ} \mathrm{C}$ в Гадячі що також згідно 3 класифрікації діапазону HEET означає дуже прохолодно (дискомфорт).

Показники радіаційно-еквівалентно-ефективної температури (РЕET) були визначені на основі HEET. Найвищі показники PEET були визначені у Полтаві, Кобеляках та Веселому Подолі і становили $+20,5^{\circ} \mathrm{C}$, найнижчі $-+20,2{ }^{\circ} \mathrm{C}$ у 
October 25, $2019 \bullet$ Edinburgh, Scotland, UK • 121

Лубнах, що згідно з класифікації діапазону РЕEТ означає комфортно, помірно тепло.

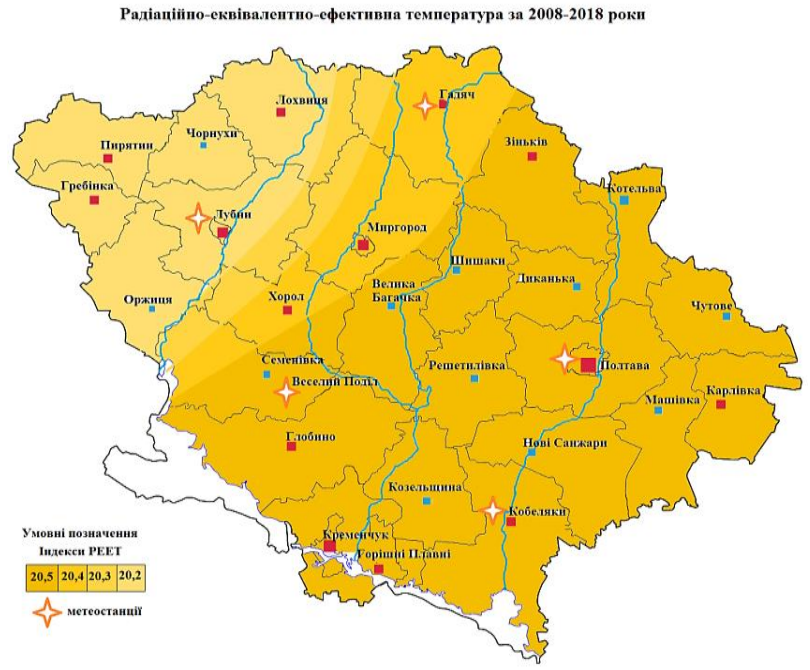

Рис. 2. Радіаційно-еквівалентно-ефективні температури за даними 2008-2018 років

Біологічно активні температури області також згідно 3 класифрікації діапазону БАТ означають комфортно, помірно тепло, і коливаються від $+22,1^{\circ} \mathrm{C}$ в Лубнах до $+22,5^{\circ} \mathrm{C}$ в Полтаві.

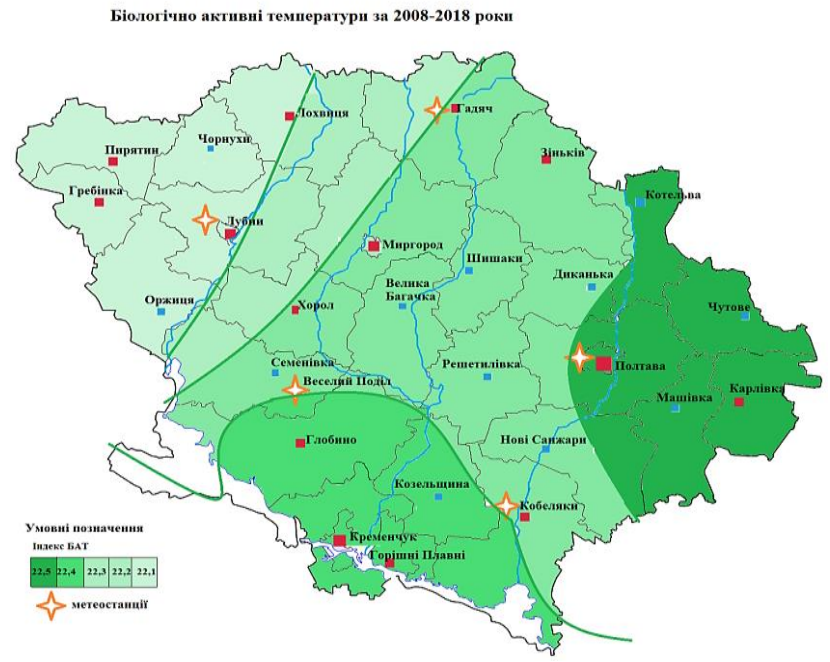

Рис. 3. Біологічно активні температури за даними 2008-2018 років 
Також нами був визначений індекс суворості погоди $\mathrm{S}$ для середньорічної температури січня, який має показники від 1,8 в Лубнах до 2,1 в Полтаві, що характеризує зиму як мало сувору, помірно-сувору.

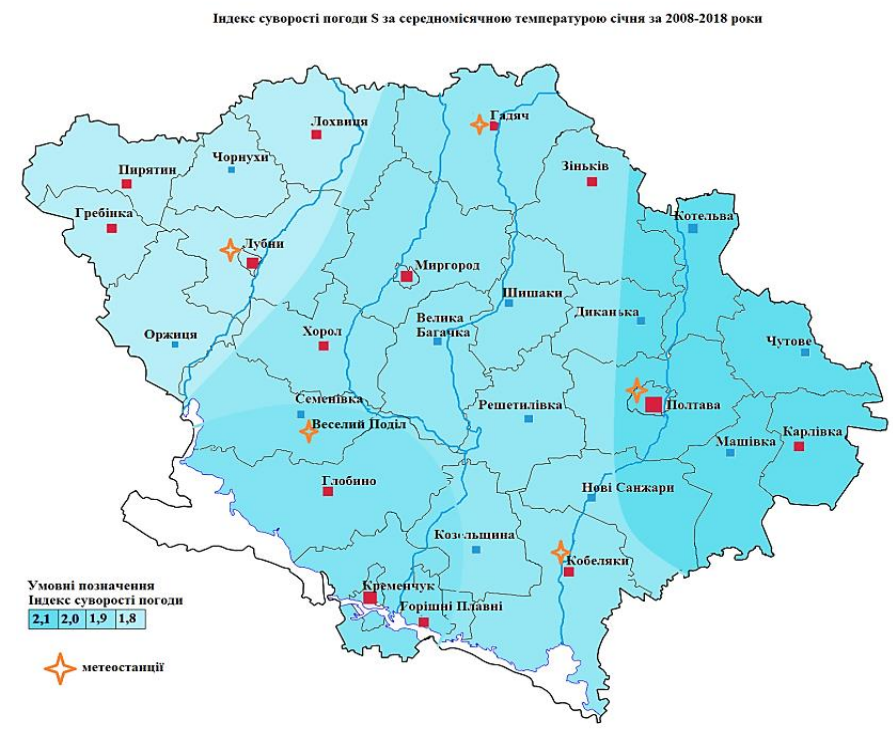

Рис. 4. Індекс суворості погоди за даними метеорологічних спостережень за 2008-2018 роки

\section{Список використаних джерел:}

1. Михайленко, Н.М.(2015). Аналіз біокліматичних чинників як умова рекреаційної діяльності. Географрія та туризм. Вісник Львівського університету (46), 129-136.

2. Стафійчук, В. І. (2008) Рекреалогія. Навчальний посібник. Київ: Альтерпрес.

3. Архів погоди в Полтавській області. Вилучено з https://rp5.ua.

4. Маца, К. О. (ред.) (2008). Полтавська область: природа населення, господарство. Географрічний та історико-економічний нарис. Полтава: Полтавський літератор. 


\section{ГЕОГРАФІЯ ЗВУКОВИХ ЛАНДШАФТІВ ПОЛТАВСЬКОї ОБЛАСТІ}

\section{Демченко Ростислав Іванович}

учень 10-М класу

Полтавський обласний науковий ліцей-інтернат імені А.С. Макаренка

Науковий керівник: Глухота Віталій Олександрович

учитель II категорії

Полтавський обласний науковий ліцей-інтернат імені А.С. Макаренка

УКРAÏHA

Згідно з класифікацією звукових ландшафтів за походженням виділено природні, антропогенні та змішані звукові ландшафти Полтавської області.

Природні звукові ландшафти області представлені перш за все гідрологічними, атмосферними, літосферними та біосферними звуковими ландшафтами [1].

Незважаючи на значну кількість гідрологічних об'єктів, та враховуючи особливості рельєфу та тектонічної будови області, відповідні гідрологічні об'єкти не завжди є джерелами звукових ландшафтів. Але найбільш широко представлені відповідні ландшафти довкола Кременчуцького та Кам'янського водосховищ, які мають значну площу, і за певних умов можуть, бути джерелами формування звукових явищ і звукових ландшафтів відповідно, або в поєднанні з іншими компонентами ландшафту [2].

Атмосферні звукові ландшафти на відмінно від гідрологічних не мають постійних джерел звуку. Особливістю атмосферних звукових ландшафтів, $€$ перш за все значна частка охоплення території, мають хронологічну залежність та досить відчутний вплив на формування інших компонентів ландшафту.

На території області найбільш відчутними відповідні звукові ландшафти в травні, червні та липні. Саме в цей період спостерігається найбільша кількість днів з дощами та грозами, але і в інші місяці також можуть функціонувати відповідні ландшафти, але 3 меншою інтенсивністю. Щодо вітру, то особливістю функціонування таких ландшафтів, зумовлено перш за все людською діяльністю. Вітер сам по собі не $є$ джерелом звуку, ми відчуваємо вітер лише при взаємодії з іншими компонентами ландшафту. Особливо така взаємодія характерна для міст з інтенсивною та багатоповерховою забудовою. На території області це зокрема міста Полтава, Кременчук, Горішні Плавні, Миргород, Лубни та інші міста де $є$ багатоповерхівки. В інших населених пунктах вітер також має відчутний вплив але вже при взаємодії з природними компонентами ландшафту, наприклад деревами [2].

Літосферні звукові ландшафти Полтавщини пов'язані перш за все, 3 обвалами на корінних берегах річок та водосховищ, зсувами в кар'єрах та іншими гравітаційними процесами. Даний вид ландшафтів найбільш широко представлений на корінних берегах річок Псел, Ворскла, Сула тощо, а також довкола кар'єрів поблизу Горішніх Плавнів. Хоча і виникають відповідні ландшафти в штучних кар'єрах, але саме звук обвалу $\epsilon$ природного походження і не контролюється людиною [2]. 
Біосфрерні звукові ландшафти формуються під впливом фрлори та фауни регіону. Як уже зазначалося, найбільший вплив серед представників фауни на формування відповідних звукових ландшафтів здійснюють птахи, та деякі види земноводних. Чітко географію даних звукових ландшафртів визначити не можливо, але все ж найбільше звукових явищ можна спостерігати в значних лісових масивах області - Диканський, Гадяцький, Полтавський, Котелевський, Великобагачанський райони. Саме там можна зустріти і почути джерела звуку: ворон, дятлів, горлиць тощо. Довкола водних об'єктів також слід відзначити: жабу озерну та ропуху звичайну, а також диких качок, очеретянок тощо. Особливістю функціонування саме біосферних ландшафтів є також певна хронологічність та сезонність. Наприклад, звуки від жаб найінтенсивніше можна почути навесні [2].

Представники орнітофауни фактично $є$ потужним природним джерелом формування джерел звуку, які завдяки неоднорідністю походження, різною тривалістю звучання формують звукові явища, що $\epsilon$ основою для функціонування звукових ландшафтів регіону [3].

До антропогенних звукових ландшафтів Полтавської області належать: транспортні, сакральні, хронологічні, інформаційні, міські, сільські, військові, промислові [3].

Транспортні звукові ландшафти $є$ одними з найпотужнішими джерелами звуку. Через територію області проходе одна $з$ важливих автомобільних магістралей країни - Київ-Харків-Довжанськ, автомобільний рух на всій ділянці $\epsilon$ досить інтенсивний, та постійний. Тому відповідні транспортні звукові ландшафти формуються довкола автомагістралі, і мають відчутний вплив на формування інших ландшафртів. Інші автомагістралі області також $є$ значним джерелом формування відповідних ландшафтів але місцевого рівня [2].

Залізничні магістралі перетинають територію області з заходу на схід та з півночі на південь, і також $є$ потужним джерелом звукових явищ. Особливо слід відзначити ділянки Полтава-Гребінка та Полтава-Кременчук (рис. 1), де інтенсивність потягів $€$ досить значною, що навіть породжує в окремих районах формування негативних або шкідливих звукових ландшафтів.

Сакральні звукові ландшафрти пов'язані з діяльністю культових споруд, зокрема церков та їх дзвонів. Відповідні ландшафти здійснюють вплив на незначні території, для них характерна певна хронологічність появи та ритмічність [3].

В Полтавські області налічується більше сотні культових споруд. Найбільше в Гадяцькому, Миргородському, Лубенському районах, а також у містах Полтава, Лубни, Миргород та інші [2].

Хронологічні звукові ландшафтти тісно пов'язані з сакральними перш за все певною ритмічністю, та особливостями звучання. Але хронологічні мають більш чітку ритмічність В області відповідні ландшафти представлені в Полтаві, Кременчуці, Миргороді, де джерелом звуку являються звукові морфоскульптури (годинки на вежах).

Інформаційні звукові ландшафти представлені перш за все у великих містах Полтава, Кременчук, Лубни, Миргород, Горішні Плавні, Гадяч, та інші. Відповідні ландшафтти являють собою також певну звукову морфоскульптуру яка $€$ джерелом формування звукових явищ в місті. Наприклад голосові інформаційні стенди, рекламні оголошення. 


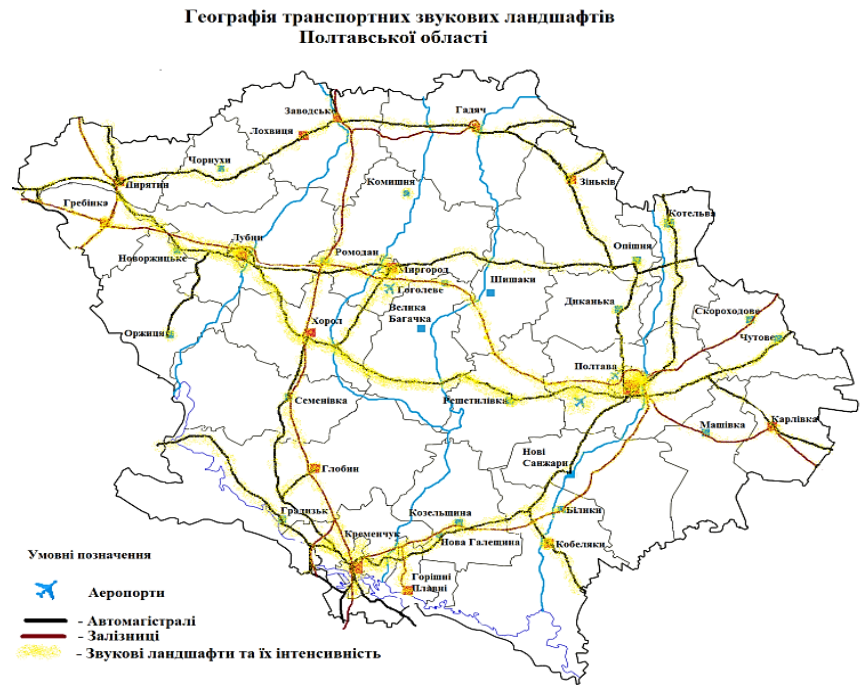

Рис 1. Географія транспортних звукових ландшафтів Полтавської області

Міські звукові ландшафрти області $\epsilon$ також потужним джерелом функціонування звукових ландшафтів у області. Вони можуть поєднувати в собі як природні так і антропогенні та змішані звукові ландшафтт. Але найбільше в даному виді представлені саме антропогенні та змішані.

В Полтавській області відповідний тип ландшафтів представлений в 36 населених пунктах (містах та селищах міського типу). Найбільшу географрію поширення мають в Кременчуцькому, Полтавському, Лохвицькому, Миргородському та Лубенському районах [2].

На поширення та фрункціонування звукових ландшафтів міста, впливає кількість жителів, наявність відповідних підприємств, які є джерелами звуків, проходження через місто залізниці та автошляхів, наявність поблизу аеропорту, тощо.

Джерелами звуків у міських ландшафтах виступають перш за все автомобілі, люди, та окремі звукові морфоскульптури міста (світлофори, фонтани, голосова реклама, тощо). Також для міських звукових ландшафтів характерним $є$ утворення звукових фрацій та урочищ. Наприклад, міські парки, підприємства, аеродроми тощо.

Сільські звукові ландшафрти фрормуються довкола майже 1806 населених пунктів області. Особливістю їх фрункціонування $€$ загальна поширеність, джерелами звуку виступають природні аналоги: шум дерев, звуки тварин тощо. Але саме функціонування даних звукових явищ відбувається в антропогенному середовищі, де і формуються відповідні сільські звукові ландшафти.

Військові звукові ландшафрти, як окремий вид на території області не представлені. Але можуть існувати під час військових навчань, чи передислокації військової техніки. Вони являються досить потужним джерелом 
звукових ефектів, що можуть створювати негативні чи шкідливі звукові ландшафти.

Промислові звукові ландшафти фрормуються довкола великих промислових об'єктів, які виступають джерелами звуків. Вони здійснюють незначний вплив в територіальному значенні, але являються потужними джерелами звуків. В області такими об'єктами являють Крюківський вагонобудівний завод, КрАЗ, ПГЗК, та інші менші об'єкти. Фактично, майже в кожному місті та окремих селищах міського типу представлений такий вид звукових ландшафтів [2].

Аналізуючи географію змішаних звукових ландшафтів Полтавської області, слід відзначити, що вони результатом поєднання природних звукових явищ через діяльність людини, або антропогенних звукових явищ через природні компоненти.

До змішаних звукових ландшафтів належать техногідрологічні, техноатмосферні, технолітосферні, тваринні, рекреаційні, масові.

Щодо техногідрологічних, то на території області функціонує 6 малих ГЕС (Шишацька, Остап'євська, Сухорабівська, Кунцівська, Великосорочинська та Опішнянська) (рис.2 ), а також гідровузли - Малобудищанський, Нижньомлинсьий та інші, які $\epsilon$ джерелами звукових явищ, і відповідно формують звукові ландшафти регіону.

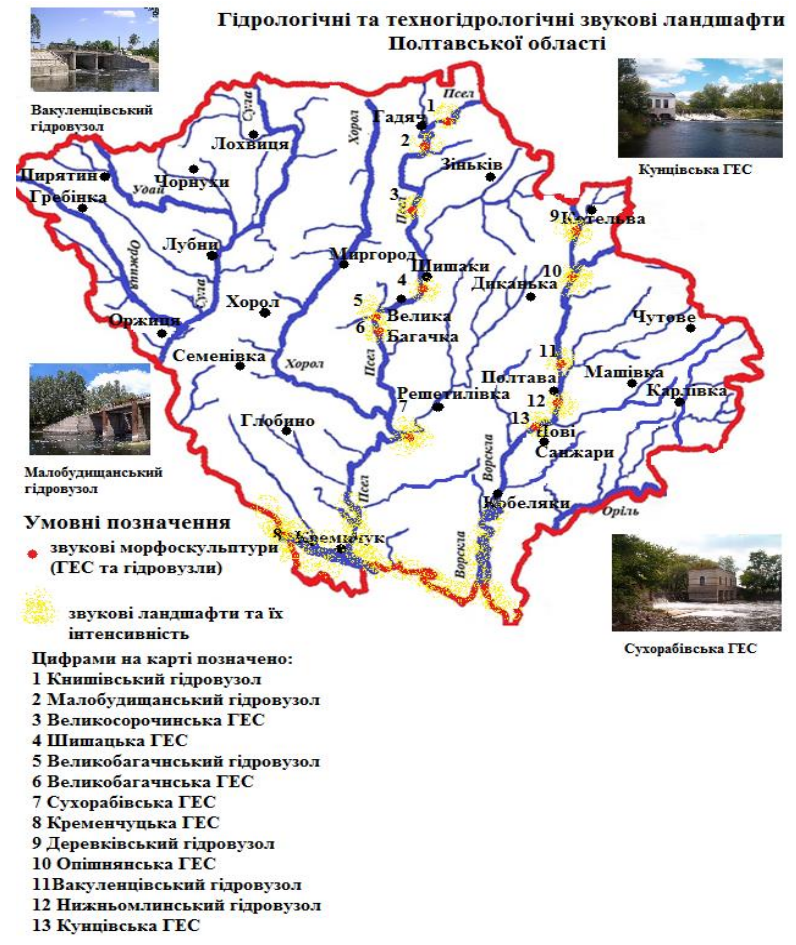

Рис 2. Гідрологічні та техногідрологічні звукові ландшафти Полтавської області 
Але найбільший вплив здійснює Кременчуцька ГЕС, хоча географрічно вона не входить до складу області, але формує відповідні звукові ландшафти, які поширюються і на територію Полтавської області

Антропоатмосфрерні звукові ландшафти являють собою опади (дощ, град, гроза), які створюють звукові ефекти різної гучності залежно від підстилаючої поверхні. В містах їх ефект буде більшим, ніж в природному середовищі. Тому і звукові явища матимуть більший ефект на формування звукових ландшафтів у містах, ніж у природному середовищі.

Технолітосферні звукові ландшафти являють собою звуки вибухів, буріння свердловин, тощо. В Полтавській області відповідні звукові ландшафти представлені в місяцях видобутку корисних копалин - Кременчуцький, Гадяцький, Лохвицький, Полтавський райони [2].

Тваринні звукові ландшафти являють собою звуки тваринного походження в населених пунктах, зазвичай такий вид ландшафтів представлений у селах, але зустрічається у в містах області.

Рекреаційний звуковий ландшафт характеризується сприятливим впливом на організм людини. Джерелами звуку виступають зазвичай природні об'єкти, що формують звукові явища які позитивно впливають на людину, в плані ритму, гучності, тембру. Географія рекреаційних звукових ландшафтів області тісно пов'язана з рекреаційним потенціалом області. Фактично будь-яке природне середовище регіону з відповідним сприятливим звуковим впливом можна розглядати як рекреаційний звуковий ландшафт.

Масові звукові ландшафрти являють собою концерти, масові гуляння, фестивалі, де основним джерелом звукових явищ є музика та інші акустичні явища і людина з ії діяльністю та природні джерела звуків.

На території області щорічно проводиться близько сотні фестивалі. Найпомітнішими з точки зору масових звукових ландшафртів являється Сорочинський ярмарок, дні міста чи села, та багато інших, які проводяться як у обласному центрі, так і в невеликих населених пунктах області.

\section{Список використаних джерел:}

1. Денисик, Г. І. (2012). Антропогенне ландшафотознавство. Вінниця: Едельвейс і К.

2. Маца, К. О. (ред.) (2008). Полтавська область: природа населення, господарство. Географрічний та історико-економічний нарис. Полтава: Полтавський літератор.

3. Дружкин, Ю. О. (2010). Звуковые ландшафты культурных пространств. Звук и отзвук, (5), 252-264. 


\section{SECTION 16. ARCHITECTURE AND ARTS}

\section{АНАЛІЗ СПОСОБІВ ПОСИЛЕННЯ ЗАЛІЗОБЕТОННИХ БУДІВЕЛЬНИХ КОНСТРУКЦІЙ}

Ігнатьєва Вікторія Борисівна

канд. техн. наук, доцент, доцент кафедри будівельних конструкцій Тернопільський національний технічний університет імені Івана Пулюя

Шинкляр Назарій Вікторович здобувач вищої освіти фракультету інженерії машин, споруд та технологій Тернопільський національний технічний університет імені Івана Пулюя

УКРӒ̈HA

В процесі експлуатації будівель і споруд періодично виникає необхідність проведення ремонтів і посилення будівельних конструкцій. Це пояснюється різними впливами на будівельні конструкції, такими як вплив агресивних хімічних середовищ, перепланування, аварії. Крім того, до проведення ремонтів можуть змушувати допущені помилки при проектуванні або відхилення від проекту при проведенні будівельних робіт.

На сьогоднішній день для посилення залізобетонних конструкцій існує безліч способів. У той же час існує проблема яка полягає у тому, що існуючі способи посилення будівельних конструкцій задовольняють не усі потреби сучасного користувача.

Метою роботи $€$ аналіз стану проблеми посилення залізобетонних будівельних конструкцій.

Сьогодні для посилення несучої здатності будівельних конструкцій використовують два способи: традиційний і нетрадиційний.

Традиційне посилення залізобетонних конструкцій здійснюється трьома основними способами. Перший спосіб - зміна конструктивної схеми. Цей спосіб $€$ одним з найбільш ефективних, особливо для елементів, що згинаються. Його суть полягає в тому, що в елементах, що підсилюються встановлюють додаткові жорсткі і пружні опори [1].

Другий спосіб - збільшення площі поперечного перерізу за рахунок влаштуванням обойм, сорочок або односторонніх і двосторонніх нарощувань перетинів конструкцій. Цей спосіб відносно простий і економічний. Недоліками способу $є$ небезпека корозії замонолічених в бетон сталевої арматури і руйнування бетону. Фізична несумісність матеріалів для ремонту зі «старим» бетоном ґрунтується на невідповідності їх міцності на стиск, розтяг, зсув, модулів пружності, коесріцієнтів температурного розширення [1].

Третій спосіб - зміна напруженого стану конструктивного елемента. Цей спосіб полягає в тому, що в розтягнутій зоні елемента, що підсилюється встановлюють переднапружені затяжки, а у колонах - попередньо напружені розпірки [1].

Спосіб підсилення конструкцій, що передбачає регулювання напружень, дозволяє зменшити зусилля, діючі в конструкції. 
До переваг посилення залізобетонних конструкцій зовнішніми арматурними елементами з попереднім напруженням відносяться:

- простота виконання робіт;

- можливість обстеження споруди протягом усього терміну ії служби;

- можливість заміни напружених арматурних елементів

- можливість контролювати зусилля натягу.

До недоліків можна віднести схильність до корозії та низьку вогнестійкість.

Посилення будівельних конструкцій традиційним способом в деяких випадках буває важко або технічно неможливо, а іноді виявляється неефективним.

До нетрадиційного способу відносять зовнішне армування будівельних конструкцій будівель і споруд композиційними матеріалами, які існують у вигляді полотен, сіток і ламінатів, наприклад, з вуглеволокна. Їх застосування дозволяє поліпшити сейсмостійкість і несучу здатність конструкцій [2].

Зовнішнє армування, що передбачає приклеювання композитних матеріалів з вуглеволокна за допомогою спеціальних епоксидних смол, має ряд переваг:

- висока міцність при розтягуванні;

- високий модуль пружності;

- стійкість практично до всіх агресивних середовищ - кислот, лугів і розчинників;

- водонепроникність;

- стійкість конструкцій в сейсмічно небезпечних зонах;

- з'єднання з конструкцією тільки за допомогою клею;

- невелику власну вагу, тобто, незначне додаткове навантаження на конструкцію;

- легкість монтажу, що не вимагає спеціального оснащення;

- можливість покриття фарбами, що дає можливість повністю приховати посилення [2].

Основні недоліки:

- висока вартість композиційних матеріалів;

- композиційні матеріали не володіють пластичними властивостями (погані пластичні властивості композиційних матеріалів не сприяють перерозподілу напружень в конструкції, що підсилюється) та їх руйнування носить крихкий характер;

- відсутність опірності високим температурам, що вимагає додаткового захисту систем посилення протипожежними заходами.

3 огляду на високу вартість композитної вуглепластикової арматури, в ряді країн розробляється комбінована арматура. Така арматура складається 3 несучого сердечника з вуглепластика, покритого базальтовою оболонкою. Комбінована арматура дешевше ніж арматура з вуглепластика, але має більш низькі фрізико-механічні властивості. 3 іншого боку, така арматура в кілька разів краще сталевої арматури.

Висновки. Аналіз стану проблеми посилення залізобетонних будівельних конструкцій показав, що ця проблема освітлена сучасними дослідниками не в повній мірі і $\epsilon$ великий потенціал для розробки нових способів посилення залізобетонних будівельних конструкцій й удосконалення вже існуючих. 
1. Дорофеев, В. С., Заволока, М. В., Заволока, Ю. В., Заволока, Ю. М. \& Рогачко, Е. И. Усиление железобетонных конструкций элементами внешнего армирования из высокоэфрфективных композитных материалов на основе высокопрочных волокон. Изъято из https://docplayer.ru/76654787-Usilenie-zhelezobetonnyh-konstrukciy-elementamivneshnego-armirovaniya-iz-vysokoeffektivnyh-kompozitnyh-materialov-na-osnovevysokoprochnyh-volokon.html.

2. Ovchinnikov, I. G., Valiev, S. N., Ovchinnikov, I. I., Zinoviev, V. S. \& Umirov, A. D. (2012). Use the composites for strengthening reinforced concrete: Experimental studies of the composites strengthening for flexural reinforced concrete structures. Интернет-журнал «Науковедение», (4). Изъято из https://cyberleninka.ru/article/v/voprosy-usileniya-zhelezobetonnyh-konstruktsiykompozitami-1-eksperimentalnye-issledovaniya-osobennostey-usileniya-kompozitami.

DOI 10.36074/25.10.2019.v3.13

\section{ОСНОВНІ НАПРЯМКИ ЗАСТОСУВАННЯ ВЕЧІРНЬОГО I НІЧНОГО ОСВІТЛЕННЯ ПРИШКІЛЬНИХ ТЕРИТОРІЙ}

Коваль Лідія Михайлівна

канд. мистецтвознавства, доцент, докторант кафедри архітектурних конструкцій Київський національний університет будівництва і архітектури

УКРӒ̈̈А

Школи, як правило, оточені великими відкритими майданчиками: внутрішніми двориками, газонами, скверами та садами, а також стоянками для автомобілів, мотоциклів та велосипедів, під'їзними дорогами. Освітлення, призначене для шкільних територій, повинне бути достатньо яскравим, перш за все, щоб мінімізувати ризик нещасних випадків. Школярі та вчителі, а також відвідувачі шкільних концертів та інших вечірніх заходів мають почуватися у безпеці [1]. Параметри освітлення пришкільних територій обумовлюються призначенням відповідної функціональної зони земельної ділянки освітнього закладу, за класифрікацією згідно ДБН В.2.2-3:2018 [2].

Фізкультурно-спортивна зона, у тому числі шкільний стадіон. Більшість спортивних майданчиків освітлюються прожекторами, встановленими на чотирьох або шести стовпах, які розташовуються по кутах або довших сторонах прямокутного майданчика. Чим вищі ліхтарі, тим краще обмежуються відблиски. Аби не допустити появи недоречних тіней, світло прожекторів повинне бути спрямоване так, щоб кожна точка освітлювалась принаймні двома з них. Необхідно виключити можливість засліплення глядачів [1].

Зона відпочинку, у тому числі ділянки для рухливих ігор перших класів. Зазвичай пришкільні території використовуються у всі пори року і в будь-яку погоду як місце відпочинку, спорту та ігор. Гарне освітлення допомагає школярам під час гри визначати перешкоди і легше розпізнавати об'єкти, наприклад ігровий м'яч, тим самим підвищуючи їхню безпеку. Всі світильники мають бути призначеними для використання на вулиці і мати відповідний захист від вологи та бути ударостійкими [1]. 
Навчально-дослідна зона, у тому числі теплиця. Сучасні технології освітлення теплиць, що базуються на використанні обмеженого спектра випромінювання, а саме на світлі червоних та синіх світлодіодів, здатні забезпечувати рослини енергоощадним і ефективним джерелом світла впродовж усього року [3]. Таке устаткування дозволяє контролювати процес росту рослин і може стати сучасною версією шкільного городу, заохочуючи школярів до процесу спостереження за рослинами, надаючи можливості для експериментів та проектної роботи.

Господарська зона. Серед загальних рекомендованих рівнів освітленості для цієї зони пришкільних територій є такі: відкриті простори - 3 лк; периметр зони службового користування - 5 лк; автостоянка - 11 лк; місця завантаження і розвантаження - 165 лк; внутрішній простір зовнішніх структур і конструкцій 110-220 лк; автомобільні в"їзди - 110 лк [4]. На під"їзних дорогах та місцях паркування освітлення не повинне створювати відблиски, тому необхідно освітити всі ділянки, що використовуються автотранспортом, щоб автомобілісти та велосипедисти могли легко орієнтуватися і оперативно виявляти перешкоди та інших учасників дорожнього руху [1].

Декоративне освітлення $€$ важливою складовою вечірнього і нічного освітлення, що значно впливає на емоційний стан людини. Зовнішнє декоративне освітлення має сприяти естетичному задоволенню користувача, забезпечуючи мінімальне світлове забруднення за рахунок використання енергозберігаючих освітлювальних систем [4]. Для створення художнього світлового образу будівлі або цілого ансамблю у вечірній час доби архітектор і світлотехнік можуть використовувати набір таких технічних прийомів: загальне заливальне освітлення; локальне освітлення; світлові фрасади; силуетне освітлення; світлова графріка; ілюмінаційне освітлення; контурне освітлення; ландшафтне освітлення; динамічне освітлення [5].

Належне освітлення пришкільних територій у темний період доби може значно підвищити рівень безпеки шкіл. Як засіб запобігання та попередження злочинності у школах, вечірнє та нічне освітлення вирішує дві основні задачі: створення відповідного психологічного впливу, що попереджує вторгнення; сприяння виявленню вторгнення. Для забезпечення роботи звичайних камер відеоспостереження необхідні такі мінімальні рівні освітленості: виявлення 5-6 лк, упізнавання - 10-11 лк, ідентифікація - 21-22 лк. Для освітлення сторожових приміщень рекомендовано: двері (ворота) - 270-325 лк, внутрішнє приміщення - 325 лк. Наступні заходи можуть покращити захисні фрункції освітлення [4]:

- визначення світлового периметру для забезпечення освітлення з обох сторін огорожі, забезпечення направленого вниз освітлення для створення засліплення при спробах вторгнення;

- використання датчиків руху для вмикання і вимикання певної частини освітлення зовнішніх і внутрішніх просторів, забезпечення наявності переносних аварійних ліхтарів у разі відмови централізованого живлення;

- організація зовнішнього освітлення без темних проміжків між світловими ділянками, що унеможливить непомітне пересування до об'єкта;

- організація мінімального чергового освітлення внутрішніх приміщень, що покращить умови спостереження для охорони. 
Висновки. Отже, у процесі дослідження визначено і охарактеризовано основні напрямки застосування вечірнього і нічного освітлення пришкільних територій, а саме:

- штучне освітлення функціональних зон різного призначення;

- декоративне освітлення;

- освітлення для безпеки шкіл.

У майбутньому, в межах даної тематики, доцільно дослідити штучне та суміщене освітлення шкільних приміщень різного призначення.

\section{Список використаних джерел:}

1. Good Lighting for Schools and Educational Establishments. Information on Lighting Applications Booklet 2. (2000). Frankfurt/Main: Fördergemeinschaft Gutes Licht (FGL).

2. Будинки і споруди. Заклади освіти (Державні будівельні норми України). ДБН В.2.2-3:2018. (2018). Київ: Мінрегіон України.

3. Освітлювальна технікадля агрономів компанії Philips. (2019). Вилучено 3 http://www.lighting.philips.ua/products/horticulture.

4. Perry, M. \& Fennelly, L. (2014). The Handbook for School Safety and Security. Waltham, USA: Butterworth-Heinemann is an imprint of Elsevier.

5. Лісна, О. І. (2010). Декоративно-художнє освітлення архітектурного середовища. Харків: ХНАМГ.

\section{ФУНКЦІЇ СЕНСОРНИХ ТЕХНОЛОГІЙ В ДИЗАЙНІ ІНТЕР'ЄРІВ ЗАГАЛЬНООСВІТНЬОЇ ШКОЛИ}

Катріченко Ксенія Олександрівна аспірант Харківська державна академія дизайну і мистецтв Науковий керівник: Гончар Олена Валентинівна доктор педагогічних наук, професор кафедри педагогіки і філології Харківська державна академія дизайну і мистецтв

УКРАÏHA

Сенсорні технології XXI століття принципово змінюють концепцію сучасної загальноосвітньої школи. Їх взаємозалежність визначає і відображає композиційно-змістовну цілісність дизайну навчального середовища, створеного інноваційними засобами сенсорних технологій. Аналіз матеріалу показав, що узгодженість асоціативних значень, закодованих в проектних пропозиціях сенсорних технологій 3 асоціативними уявленнями - той ідеальний випадок, коли формується єдиний асоціативний образ, що безпосередньо демонструє художню та естетичну цінності інтерактивного простору школи.

Слід зазначити, що навчання в інклюзивних освітніх закладах корисне як для дітей з особливими освітніми потребами, так і для інших дітей, членів родин та суспільства в цілому. Взаємодія зі здоровими дітьми сприяє когнітивному, фрізичному, мовному, соціальному та емоційному розвиткові 
дітей з особливими освітніми потребами. Отже, формування дизайну класних кімнат школи за допомогою сенсорних технологій створює можливості для дослідження природи реакцій всіх учнів без винятку.

Серед основних технологій, що використовуються для покращення поведінки, психічного стану та реакцій учнів, можна назвати бульвашкові трубки (Bubble Tubes) та «Світловий дощ». Запропоновані сенсорні технології Bubble Tubes та сенсорний комплекс "Світловий дощ» в формуванні дизайну класної кімнати є частиною обладнання Sensory Rooms, які виконують декілька важливих функцій: технологічну, терапевтичну, когнітивну, естетичну, виховну. Наприклад:

- технологічна: функція відповідає за можливість миттєвого керування обладнанням; має легкий доступ та інтерактивне керування Switch4;

- терапевтична: а) специфіка технології Bubble Tubes виявляється в її заспокійливому ефекті, терапевтичному впливі на нервову систему, загальному розслабленні учня. Всі означені вище складові відбуваються під впливом плавного руху бульбашок, що підсвічені різними кольорами; б) специфріка «Світлового дощу» являє собою світлову конструкцію, виготовлену за типом люстри, декоровану 150-ма оптичними волокнами, завдяки яким виявляється терапевтичний вплив на нервову систему;

- когнітивна: покращує зір, слух і дотик при взаємодії учня із елементами сенсорних технологій. Для підвищення результативності учня дана фрункція $\epsilon$ основою при проведенні занять з фізіотерапії. Обладнання має легкий доступ для інвалідних колясок, що дозволяє учневі торкатися трубки інтерактивного пристрою і притискатися до неї;

- естетична: вісім змін кольору «світлового дощу», які випромінюють м'яке, заспокійливе світло та бульбашкові панелі - використовують в рішенні дизайну класної кімнаті в якості декоративного, заспокійливого обладнання, що позитивно діє на психо-емоційний стан учнів. Яскраві, барвисті бульбашки також забезпечують звук, вібрацію та мають захоплюючий візуальний досвід для учнів;

- виховна: розвиває здібності учнів, формує позитивне ставлення до навколишнього середовища, друзів. Крім того, важливим $€$ формування позитивно збуджуючих мотивів, які мають можливість ознайомитися зблизька із предметом естетичного вигляду.

Висновки: Всі перераховані сенсорні технології можуть використовуватися як розвиваюче обладнання в фрормуванні дизайну сенсорної кімнати загальноосвітньої школи або для вирішення сенсорного куточка класної кімнати. В комплексі зі світловими і звуковими ефектами сенсорне обладнання допомагає вирішувати важливі питання, пов'язані із терапевтичною функцією, яка створює умови для заспокійливих дій. Цей фракт доведений працями вчених, невропатологів і педіатрів всього світу.

Аналіз матеріалу показав, що сенсорні здібності учня змінюються протягом усього його життя. Означене вище підтверджує необхідність використання в дизайні загальноосвітньої школи сенсорних технологій, які допомагають дизайнерам підтримувати позитивну різноманітність психо-емоційного стану учнів незалежно від їх здоров'я, вікової категорії та, як результат, впливати на покращення учбового процесу. 


\section{КОГОГ}

COLLECTION OF SCIENTIFIC PAPERS

\section{WITH PROCEEDINGS OF THE INTERNATIONAL SCIENTIFIC AND PRACTICAL CONFERENCE \\ «SCIENTIFIC DISCOVERIES: PROJECTS, STRATEGIES AND DEVELOPMENT »}

October 25, 2019 • Edinburgh, Scotland, UK

\section{VOLUME 3}

English, Ukrainian, Russian and Scottish Gaelic

All papers have been reviewed

Organizing committee may not agree with the authors' point of view Authors are responsible for the correctness of the papers' text

Signed for publication 25.10.2019. Format 60×84/16 Offset Paper. The headset is Arial. Digital printing.

Conventionally printed sheets 7,79 .

Circulation: 100 copies.

Printed from the finished original layout.

Contact details of the organizing committee:

21037, Ukraine, Vinnytsia, Zodchykh str. 18, office 81

NGO European Scientific Platform

Tel.: +38 $0981948380 ;+380981956755$

E-mail: info@ukrlogos.in.ua

URL: www.ukrlogos.in.ua 